ENVIRONMENTAL

\title{
OSTI
}

RESTORATION

PROGRAM

\section{Surface Radiological Investigations along State Highway 95, Lagoon Road, and Melton Valley Drive, Oak Ridge Reservation, Oak Ridge, Tennessee}

\author{
P. F. Tiner \\ M. S. Uziel \\ D. E. Rice
}

J. K. Williams 
This report has been reproduced directly from the best available copy.

Avallable to DOE and DOE contractors from the Office of Scientific and Technical Information, P.O. Box 62, Oak Ridge, TN 37831; prices available from 615-576-8401, FTS 626-8401.

Available to the public from the National Technical Information Service, U.S. Department of Commerce, 5285 Port Royal Rd., Springfield, VA

22161. 
Energy Systems Environmental Restoration Program

ORNL Environmental Restoration Program

\section{Surface Radiological Investigations along State Highway 95, Lagoon Road, and Melton Valley Drive, Oak Ridge Reservation, Oak Ridge, Tennessee}
P. F. Tiner
M. S. Uziel
D. E. Rice

J. K. Williams

Date Issued-August 1995

Prepared by

Health Sciences Research Division

Oak Ridge National Laboratory

Prepared for

U.S. Department of Energy

Office of Environmental Restoration and Waste Management under budget and reporting code EW 20

OAK RIDGE NATIONAL LABORATORY

Oak Ridge, Tennessee 37831-6285

managed by

LOCKHEED MARTIN ENERGY SYSTEMS, INC.

for the

U.S. DEPARTMENT OF ENERGY

under contract DE-AC05-84OR21400 


\section{Author Affiliations}

P. F. Tiner, M. S. Uziel, D. E. Rice, and J. K. Williams are members of the Measurement Applications and Development Group of the Health Sciences Research Division, Oak Ridge National Laboratory, Lockheed Martin Energy Systems, Inc., Oak Ridge, Tennessee. 


\section{CONTENTS}

FIGURES $\ldots \ldots \ldots \ldots \ldots \ldots \ldots \ldots \ldots \ldots \ldots \ldots \ldots \ldots \ldots \ldots \ldots \ldots \ldots$

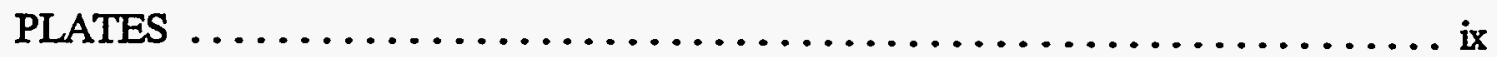

TABLES $\ldots \ldots \ldots \ldots \ldots \ldots \ldots \ldots \ldots \ldots \ldots \ldots \ldots \ldots \ldots \ldots \ldots \ldots \ldots \ldots \ldots \ldots \ldots$

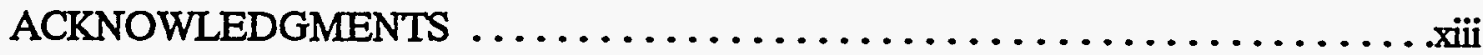

PREFACE $\ldots \ldots \ldots \ldots \ldots \ldots \ldots \ldots \ldots \ldots \ldots \ldots \ldots \ldots \ldots \ldots \ldots \ldots \ldots \ldots \ldots$

EXECUTIVE SUMMARY $\ldots \ldots \ldots \ldots \ldots \ldots \ldots \ldots \ldots \ldots \ldots \ldots \ldots \ldots \ldots$ xvii

1. INTRODUCTION $\ldots \ldots \ldots \ldots \ldots \ldots \ldots \ldots \ldots \ldots \ldots \ldots \ldots \ldots \ldots \ldots \ldots$

2. GENERAL SURVEY METHODS AND RESULTS $\ldots \ldots \ldots \ldots \ldots \ldots \ldots$

2.1 GAMMA RADIATION $\ldots \ldots \ldots \ldots \ldots \ldots \ldots \ldots \ldots \ldots \ldots, \ldots \ldots \ldots$

2.2 BETA-GAMMA RADIATION $\ldots \ldots \ldots \ldots \ldots \ldots \ldots \ldots \ldots \ldots, 4$

2.3 ENVIRONMENTAL SAMPLES $\ldots \ldots \ldots \ldots \ldots \ldots \ldots \ldots \ldots \ldots$

2.4 PROGRESS AND PRESENTATION OF THE SURVEY . . . . . . . 4

3. SPECIFIC SURVEY METHODS AND RESULTS $\ldots \ldots \ldots \ldots \ldots \ldots \ldots$

3.1 STATE HIGHWAY 95 SOUTH OF THE LAGOON ROAD

INTERSECTION $\ldots \ldots \ldots \ldots \ldots \ldots \ldots \ldots \ldots \ldots \ldots \ldots \ldots, 7$

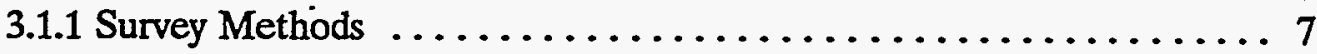

3.1.2 Survey Results Section A . . . . . . . . . . . . . . . 7

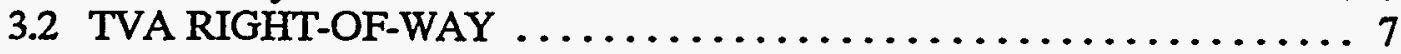

3.2.1 Survey Methods .......................... 7

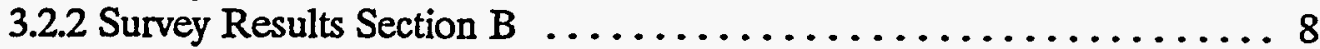

3.3 STATE HIGHWAY 95 AT INTERSECTION WITH LAGOON

ROAD $\ldots \ldots \ldots \ldots \ldots \ldots \ldots \ldots \ldots \ldots \ldots \ldots \ldots \ldots, \ldots \ldots \ldots$

3.3.1 Survey Methods $. \ldots \ldots \ldots \ldots \ldots \ldots \ldots \ldots \ldots \ldots \ldots, 8 \ldots \ldots, \ldots$

3.3.2 Survey Results Section B $\ldots \ldots \ldots \ldots \ldots \ldots \ldots \ldots \ldots \ldots$

3.4 LAGOON ROAD $\ldots \ldots \ldots \ldots \ldots \ldots \ldots \ldots \ldots \ldots \ldots \ldots \ldots$

3.4.1 Survey Methods .......................... 9

3.4.2 Lagoon Road Survey Results Section B $\ldots \ldots \ldots \ldots \ldots \ldots \ldots . . \ldots$

3.4.3 Lagoon Road Survey Results Section C ................. 10

3.4.4 Lagoon Road Survey Results Section D .................. 10

3.4.5 Lagoon Road Survey Results Section E .................. 11

3.4.6 Lagoon Road Survey Results Section F . . . . . . . . . . . . 12

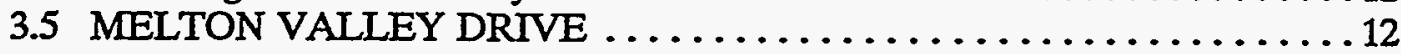

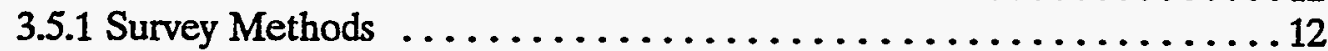

3.5.2 Melton Valley Drive Survey Results Section F . . . . . . . . . 13

3.5.3 Melton Valley Drive Survey Results Section G . . . . . . . . . . 13

3.5.4 Melton Valley Drive Survey Results Section H ............. 14 


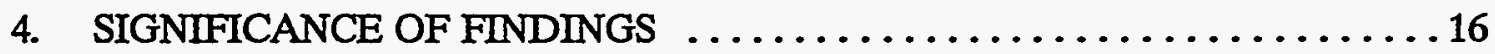

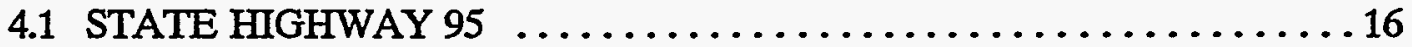

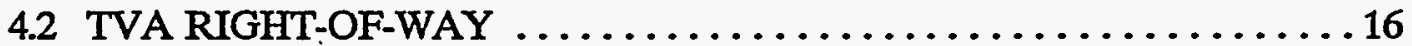

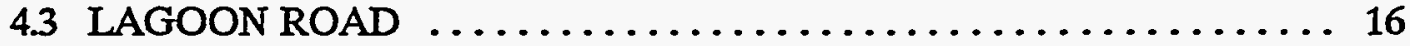

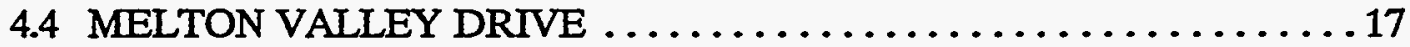

4.5 REMEDIATION ACTIVITIES $\ldots \ldots \ldots \ldots \ldots \ldots \ldots \ldots \ldots \ldots \ldots \ldots \ldots$

5. RECOMMENDATIONS ............................. 19

5.1 SYSTEMATIC SURFACE BETA-RADIATION SCAN

OF MELTON VALLEY . ........................ 19

5.2 COMPREHENSIVE RISK ASSESSMENT $\ldots \ldots \ldots \ldots \ldots \ldots \ldots \ldots 20$

5.3 INTERIM CORRECTIVE MEASURES $\ldots \ldots \ldots \ldots \ldots \ldots \ldots \ldots \ldots$

5.3.1 Isolation of Contaminated Soil/Vegetation Areas ........... 20

5.3.2 Minimization of Dispersion and Redistribution of Fugitive Radionuclides ........................ 21

5.3.3 Removal, Treatment, and Disposal of Contaminated

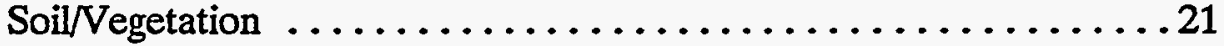

5.3 .4 Closure of Lagoon Road $\ldots \ldots \ldots \ldots \ldots \ldots \ldots \ldots \ldots \ldots \ldots \ldots \ldots \ldots \ldots \ldots \ldots$

REFERENCES $\ldots \ldots \ldots \ldots \ldots \ldots \ldots \ldots \ldots \ldots \ldots \ldots \ldots \ldots \ldots \ldots \ldots \ldots \ldots \ldots \ldots$

Appendix A RESULTS OF THE SURFACE GAMMA SURVEY ALONG STATE HIGHWAY 95, LAGOON ROAD, AND MELTON VALLEY DRIVE .25

Appendix B. RESULTS OF SURFACE BETA-GAMMA SPOT-CHECK MEASUREMENTS ALONG STATE HIGHWAY 95, LAGOON

ROAD, AND MELTON VALIEY DRIVE

Appendix C. DETAIIS OF THE 100-FT GRID ESTABLISHED

ALONG STATE HIGHWAY 95, LAGOON ROAD, AND

MELTON VALLEY DRIVE

Appendix D. RESULTS OF RADIONUCLIDE ANALYSIS OF ENVIRONMENTAL SAMPLES COLLECTED ALONG

STATE HIGHWAY 95, LAGOON ROAD, AND MELTON

VALLEY DRIVE

Appendix E. PHOTOGRAPHS OF THE SURVEY AREA ALONG

STATE HIGHWAY 95, LAGOON ROAD, AND MELTON

VALLEY DRIVE 


\section{FIGURES}

1.1 Diagram showing general location of the survey area $\ldots \ldots \ldots \ldots \ldots \ldots . \ldots 2$

2.1 Diagram showing division of surveyed area into Sections $A, B, C$,

$\mathrm{D}, \mathrm{E}, \mathrm{F}, \mathrm{G}$, and $\mathrm{H}$ to facilitate reporting of results ............. 6

A.1 Diagram showing surface gamma exposure rates $(\mu R / h)$ along the east side of State Highway 95 south of the Lagoon Road

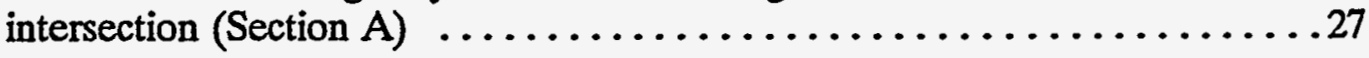

A.2 Diagram showing surface and selected 1-m gamma exposure rates $(\mu \mathrm{R} / \mathrm{h})$ near the intersection of State Highway 95 and Lagoon Road (Section B) . . . 28

A.3 Diagram showing surface and 1-m gamma exposure rates $(\mu \mathrm{R} / \mathrm{h})$ along a portion of Lagoon Road (Section C) . . . . . . . . . . . . . . 29

A.4 Diagram showing surface and 1-m gamma exposure rates $(\mu \mathrm{R} / \mathrm{h})$ along Lagoon Road in the area near Building 7819 (Section D) . . . . . . . . 30

A.5 Diagram showing surface and 1-m gamma exposure rates $(\mu \mathrm{R} / \mathrm{h})$ along a portion of Lagoon Road (Section E) $\ldots \ldots \ldots \ldots \ldots \ldots \ldots \ldots \ldots \ldots \ldots$

A.6 Diagram showing surface and 1-m gamma exposure rates $(\mu \mathrm{R} / \mathrm{h})$ near the intersection of Lagoon Road and Melton Valley Drive (Section F) . . . . 32

A.7 Diagram showing surface and selected 1-m gamma exposure rates $(\mu R / h)$ along a portion of Melton Valley Drive (Section $G) \ldots \ldots \ldots \ldots$

A8 Diagram showing surface and selected 1-m gamma exposure rates $(\mu R / \mathrm{h})$ along a portion of Melton Valley Drive (Section $H$ ) ................. 34

B.1 Diagram showing surface beta-gamma dose rates ( $\mathrm{mrad} / \mathrm{h}$ ) along the east side of State Highway 95 south of the Lagoon Road intersection $($ Section A) . . . . . . . . . . . . . . . . . . . . . . . 37

B.2 Diagram showing surface beta-gamma dose rates $(\mathrm{mrad} / \mathrm{h})$ near the intersection of State Highway 95 and Lagoon Road (Section B) .......... 38

B.3 Diagram showing surface beta-gamma dose rates ( $\mathrm{mrad} / \mathrm{h})$ along a portion of Lagoon Road (Section C)

B.4 Diagram showing surface beta-gamma dose rates ( $\mathrm{mrad} / \mathrm{h})$ along Lagoon Road in the area near Building 7819 (Section D)

B.5 Diagram showing surface beta-gamma dose rates $(\mathrm{mrad} / \mathrm{h})$ on the bank east of a natural drainage area near Building 7819 
B.6 Diagram showing surface beta-gamma dose rates (mrad/h) along

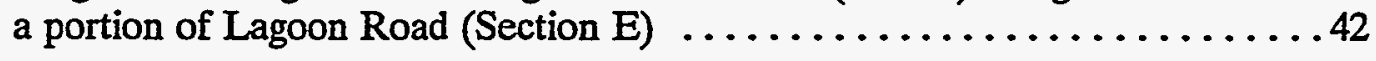

B.7 Diagram showing surface beta-gamma dose rates (mrad/h) near the intersection of Lagoon Road and Melton Valley Drive (Section F) . . . . 43

B.8 Diagram showing surface beta-gamma dose rates (mrad/h) along a portion of Melton Valley Drive (Section G) $\ldots \ldots \ldots \ldots \ldots \ldots \ldots \ldots \ldots \ldots$

B.9 Diagram showing surface beta-gamma dose rates (mrad/h) along a portion of Melton Valley Drive (Section $\mathrm{H})$....................

C.1 Diagram showing 100-ft grid established near the intersection of State Highway 95 and Lagoon Road (Section B) . . . . . . . . . . . . 49

C.2 Diagram showing 100-ft grid established along a portion of Lagoon Road (Section C). . . . . . . . . . . . . . . . . . . . . . . . 50

C.3 Diagram showing 100-ft grid established along Lagoon Road in the area near Building 7819 (Section $D)$. . . . . . . . . . . . . . . . 51

C.4 Diagram showing 100-ft grid established along a portion of Lagoon

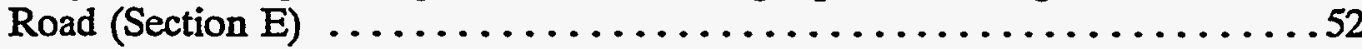

C.5 Diagram showing 100-ft grid established near the intersection of Lagoon Road and Melton Valley Drive (Section F) ..............53

C.6 Diagram showing $100-\mathrm{ft}$ grid established along a portion of Melton

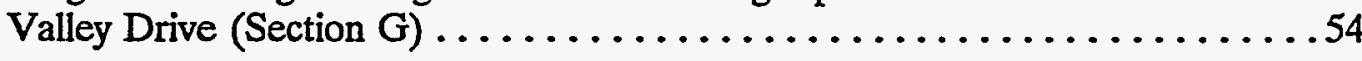

C.7 Diagram showing 100-ft grid established along a portion of Melton

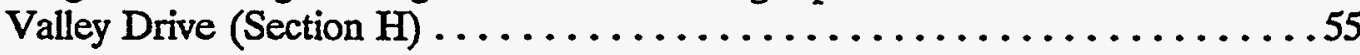

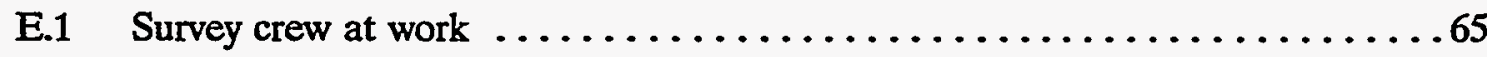

E.2 Yellow bands mark trees with elevated radiation levels $(0.04-0.12 \mathrm{mrad} / \mathrm{h})$ located near a natural drainage area east of Building 7819 (Section D)

E.3 Fallen leaves from contaminated trees cover a grating at the south end of a natural drainage area along Lagoon Road (Section D) .

E.4 Photo showing standing water, blacktop, bank, and chained contamination area depicted in Fig. B.5

E.5 A white $S$ marks the location of transferable beta-gamma activity found along Lagoon Road east of Building 7819 
E.6 View of beta-gamma pancake probe sitting on a contaminated willow tree $(0.3 \mathrm{mrad} / \mathrm{h})$ west of Lagoon Road (Section F) $\ldots \ldots \ldots \ldots \ldots \ldots \ldots .67$

E.7 Flags marking a 2- $\mathrm{ft}^{2}$ region of contamination extending outside a 6- by 18-ft posted Radiation Area west of Lagoon Road (Section F) . . . . . 68

E.8 White circles mark the locations of elevated spots identified on the road surface at the intersection of Melton Valley Drive and SWSA 5 Access Road (Section G, looking north) $\ldots \ldots \ldots \ldots \ldots \ldots 68$

E.9 Contamination Area rope erected to enclose contaminated trees found north of Melton Valley Drive (Section H) $\ldots \ldots \ldots \ldots \ldots \ldots \ldots \ldots$. . . 69

E.10 Flags mark beta-gamma anomalies $(0.08$ to $0.95 \mathrm{mrad} / \mathrm{h})$ in the grass west of the SWSA 5 Access Road (Section G) $\ldots \ldots \ldots \ldots \ldots \ldots \ldots 6 . \ldots \ldots$

E.11 Soil sample location B3 adjacent to Melton Valley Drive (Section F) $\ldots \ldots 70$

E.12 Soil sample location B4 adjacent to Melton Valley Drive (Section F) . . . . 70

E.13 Photograph of one of several concrete waste pits near Lagoon Road

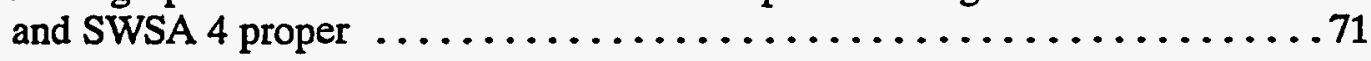

E.14 View looking east along Lagoon Road $\ldots \ldots \ldots \ldots \ldots \ldots \ldots \ldots \ldots \ldots \ldots \ldots \ldots$

E.15 View looking east along Melton Valley Drive near entrance to SWSA $5 \ldots 72$

E.16 A closer view of gravel-covered soil hot spots near Melton Valley Drive $\ldots \ldots 72$

E.17 View looking north at "flagged" surface hot spot locations near Melton Valley Drive (1994) . . . . . . . . . . . . . . . . . . . . . 73

E.18 View looking northeast at gravel-covered surface hot spot locations near Melton Valley Drive (1994) . . . . . . . . . . . . . . . . . . 73

E.19 View of State Highway 95 looking south toward intersection with Lagoon Road ................................... 74

E.20 View of hole where excavation was conducted at a surface hot spot near the east shoulder of State Highway 95 (1994) $\ldots \ldots \ldots \ldots \ldots \ldots$. . . . 74

E.21 View looking north at remediated hot spots found along the shoulder area

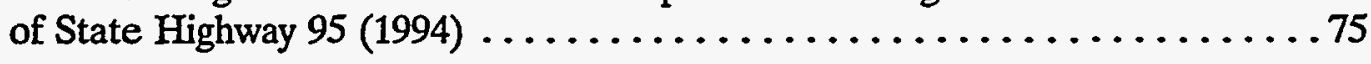





\section{PLATES}

1 Diagram showing surface and 1-m gamma exposure rates in $\mu \mathrm{R} / \mathrm{h}$ (top) and surface beta-gamma dose rates in $\mathrm{mrad} / \mathrm{h}$ (bottom) at the surveyed area along State Highway 95, Lagoon Road, and Melton Valley Drive .................... back pocket 



\section{TABLES}

D.1 Concentrations of ${ }^{60} \mathrm{Co},{ }^{137} \mathrm{Cs}$, gross alpha activity, gross beta activity, ${ }^{40} \mathrm{~K}$, and strontium in environmental samples collected along State Highway 95, Lagoon Road, and Melton Valley Drive ............. 59 


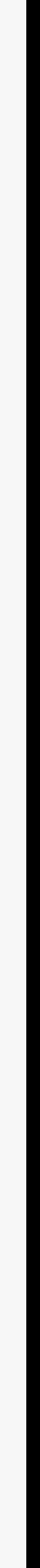




\section{ACKNOWLEDGMENTS}

This project was sponsored by the U.S. Department of Energy's Office of Environmental Restoration and Waste Management in support of the Oak Ridge National Laboratory Environmental Restoration Program. The authors wish to acknowledge the support of J. H. Hooyman, T. W. Burwinkle, L. Holder, Jr., and H. D. Wooten, of the Waste Management and Remedial Action Division, and members of their staffs. The following people participated in the field survey: J. P. Abston, J. F. Allred, A. C. Butler, J. L. Carpenter, G. H. Cofer, W. D. Cottrell, R. D. Foley, K. S. Ghers, R. C. Gosslee, D. W. Green, M. K. Jensen, D. L. Jones, J. M. Lovegrove, R. A. Mathis, S. P. McKenzie, D. D. McKinney, M. E. Murray, V. P. Patania, M. B. Patton, D. E. Rice, D. A. Roberts, D. A. Rose, M. A. Rose, J. R. Sauvage, T. S. Setser, W. H. Shinpaugh, P. F. Tiner, J. Wade, M. E. Ward, M. G. Williams, J. K. Williams, W. Winton, and J. C. Wright. T. W. Bryant downloaded the basic drawing outlines of roads, buildings, waste lines, and fences from MapInfo . R. L. Coleman calculated the conversion factors and plotted Plate 1.R. F. Carrier, W. D. Cottrell, and M. E. Murray provided valuable reviews of the draft report. 


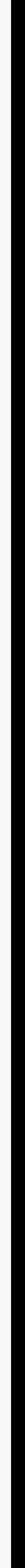




\section{PREFACE}

The surface radiological investigation along State Highway 95, Lagoon Road, and Melton Valley Drive at the Oak Ridge Reservation was conducted as part of the Oak Ridge National Laboratory Environmental Restoration Program Surveillance and Maintenance activities. This report (ORNL/ER-327) was prepared to document results of the investigation and subsequent remedial actions. This work was performed under Work Breakdown Structure 1.4.12.6.1.1.4.01.01 (Activity Data Sheet 3314, "Surveillance and Maintenance"). The report details surface gamma radiation levels including gamma anomalies; surface beta radiation levels including beta anomalies; results of analysis of soil, water, and vegetation samples and smear samples collected from paved surfaces; remediation activities conducted as a result of the survey; and recommendations for further corrective measures. 


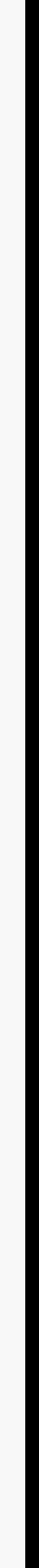




\section{EXECUTIVE SUMMARY}

A surface radiological investigation was conducted intermittently from March 1993 through June 1994 along sections of State Highway 95, Lagoon Road, and Melton Valley Drive.

\section{State Highway 95}

On State Highway 95 between White Oak Dam and the intersection with Lagoon Road, no elevated gamma exposure rates or beta-gamma dose rates were detected in the east emergency lane or between the edge of the road and the survey boundary $\sim 50 \mathrm{ft}$ east.

Immediately north of the intersection with Lagoon Road, $\sim 15$ spots with elevated gamma exposure rates $(15$ to $100 \mu \mathrm{R} / \mathrm{h})$ and elevated beta-gamma dose rates $(0.06$ to $0.38 \mathrm{mrad} / \mathrm{h})$ were identified 6 to $8 \mathrm{ft}$ from the east side of the road. One spot with elevated gamma activity $(20 \mu \mathrm{R} / \mathrm{h})$ was detected on the west side of State Highway 95 and another $(100 \mu \mathrm{R} / \mathrm{h}) \sim 450 \mathrm{ft}$ north of the intersection on the east side. No other elevated radiation levels were detected up to $950 \mathrm{ft}$ north of the intersection. Three soil samples contained ${ }^{137} \mathrm{Cs}$ as the predominant contaminant; one sample also contained ${ }^{90} \mathrm{Sr}$. All elevated radiation levels along State Highway 95 were reported to the ORNL Office of Radiation Protection, which took immediate responsibility for personnel safety and cleanup actions. Approximately $72 \mathrm{ft}^{3}$ of contaminated soil was excavated.

\section{Tennessee Valley Authority (TVA) Right-of-Way}

A roped radiological area extending $-500 \mathrm{ft}$ southeast of State Highway 95 in the cleared area beneath the transmission lines contained numerous scattered spots with elevated surface gamma exposure rates $(14$ to $67 \mu \mathrm{R} / \mathrm{h})$ and beta-gamma dose rates $(0.04$ to $0.18 \mathrm{mrad} / \mathrm{h})$. (Typical background surface gamma exposure rates in this area ranged from 4 to $14 \mu \mathrm{R} / \mathrm{h}$, beta-gamma dose rates ranged from 0.01 to $0.03 \mathrm{mrad} / \mathrm{h}$.) Two spots were detected outside the magenta and yellow rad rope near State Highway 95. Cesium-137 was the primary contaminant both inside and outside the rad rope.

\section{Lagoon Road and Melton Valley Drive}

At the western end of Lagoon Road between State Highway 95 and the ORNL Security Gate, numerous spots with elevated beta-gamma dose rates were identified north of the road. Two of the spots contained hot particles measuring 23 and $24 \mathrm{mrad} / \mathrm{h}$; beta emitters were ${ }^{137} \mathrm{Cs}$ and ${ }^{90} \mathrm{Sr}$. All spots in this area were remediated by the survey team.

East of the security gate, numerous spots and areas of elevated gamma and beta-gamma radiation levels were identified both north and south of Lagoon Road and Melton Valley Drive and on the road surface. However, no transferable contamination was found on the road surface. Cesium- 137 was the primary contaminant in soil and strontium in vegetation; ${ }^{60} \mathrm{Co}$ was also present. 
On Lagoon Road, $\sim 25$ trees with elevated beta radiation levels on trunks and leaves were identified in an area west of Building 7819. East of Building 7819, $\sim 40$ trees with elevated beta levels were identified along a natural drainage gully; contaminated leaves were scattered along both sides of the road. North of Melton Valley Drive, a large group of trees growing near a previously remediated waste line leak site showed high beta activity. Strontium was the primary contaminant.

Radiation emanating from SWSA 4 and from the White Oak Creek floodplain near the Lagoon Road intersection with Melton Valley Drive resulted in elevated background gamma exposure rates proximate to these areas. In such situations, elevated background gamma exposure rates may be masking low-level gamma anomalies located in these areas.

Animal and plant life reflect the current state of the environment along Lagoon Road and Melton Valley Drive. Elevated beta-gamma dose rates were noted in a turtle shell, an animal bone, a caterpillar squashed on the road, a live caterpillar, three snails beside the road, deer droppings, a root, numerous leaves and twigs scattered along the roadside, a sweet gum tree, a willow tree, and the three sizeable stands of trees discussed above.

\section{Remediation Activities}

Contaminated leaves along both sides of the road near Building 7819 were removed for disposal. Approximately 50\% of the elevated spots that were identified in soil were remediated by sampling. All unremediated spots exceeding guidelines established by ORNL Health Physics procedures in effect at the time of the survey were reported to the ORNL Office of Radiation Protection (ORP). The ORP was then responsible for cleanup, roping, or whatever remediation was judged appropriate.

Although areas with contaminated trees have been roped off, the vegetation continues to take up strontium from the soil. Contaminated tree leaves, which are not confined by the rope boundary, will continue to be deposited on the ground surface and subsequently distributed throughout the area.

\section{Recommendations}

The presence of above-background surface radiation measurements and concentrations of beta- and beta-gamma emitting radionuclides along sections of State Highway 95, Lagoon Road, and Melton Valley Drive warrant corrective measures. The following recommendations are presented for consideration:

- A systematic surface beta-radiation scan of Melton Valley.

- A comprehensive risk assessment of potential exposures to the public.

- Interim corrective measures, including isolation of contaminated areas; minimization of dispersion and redistribution of fugitive radionuclides; removal, treatment, and disposal of certain contaminated media; and closure of Lagoon Road. 


\section{INTRODUCTION}

A surface radiological investigation was conducted intermittently from March 1993 through June 1994 along sections of State Highway 95, Lagoon Road, and Melton Valley Drive. The survey was performed by the Measurement Applications and Development (MAD) Group, Health Sciences Research Division, Oak Ridge National Laboratory (ORNL) at the request of ORNL Environmental Restoration (ER) Program personnel.

The stimulus for this investigation was provided by a contamination incident occurring in February 1992. At that time, a nongovernment vehicle became mired in the mud along a drainage ditch on the west side of the HFIR Access Road. During the vehicle extraction process, a previously undetected region of radioactively contaminated subsurface soil was uncovered. Two cars and the shoe soles of six persons helping to free the vehicle from the mud became contaminated. The contaminated soil area was subsequently determined to be positioned directly above several underground waste lines (Williams et al. 1993).

The incident raised the following questions: (1) Are there other areas of radioactively contaminated soil on or near major roadways in the ORNL area? (2) Have other previously undetected leaks occurred along the waste lines? Therefore, this surface radiological survey was undertaken to

1. determine whether surface contamination is present along the route of waste lines located near sections of Melton Valley Drive and Lagoon Road;

2. determine the presence, nature, and extent of surface radiological contamination on and near the specified roads; ${ }^{1}$ and

3. recommend corrective actions to limit human exposures to radioactivity and minimize the potential for contaminant dispersion.

The general area of the survey in shown in Fig. 1.1.

\footnotetext{
${ }^{1}$ Portions of State Highway 95 were later included in the survey.
} 


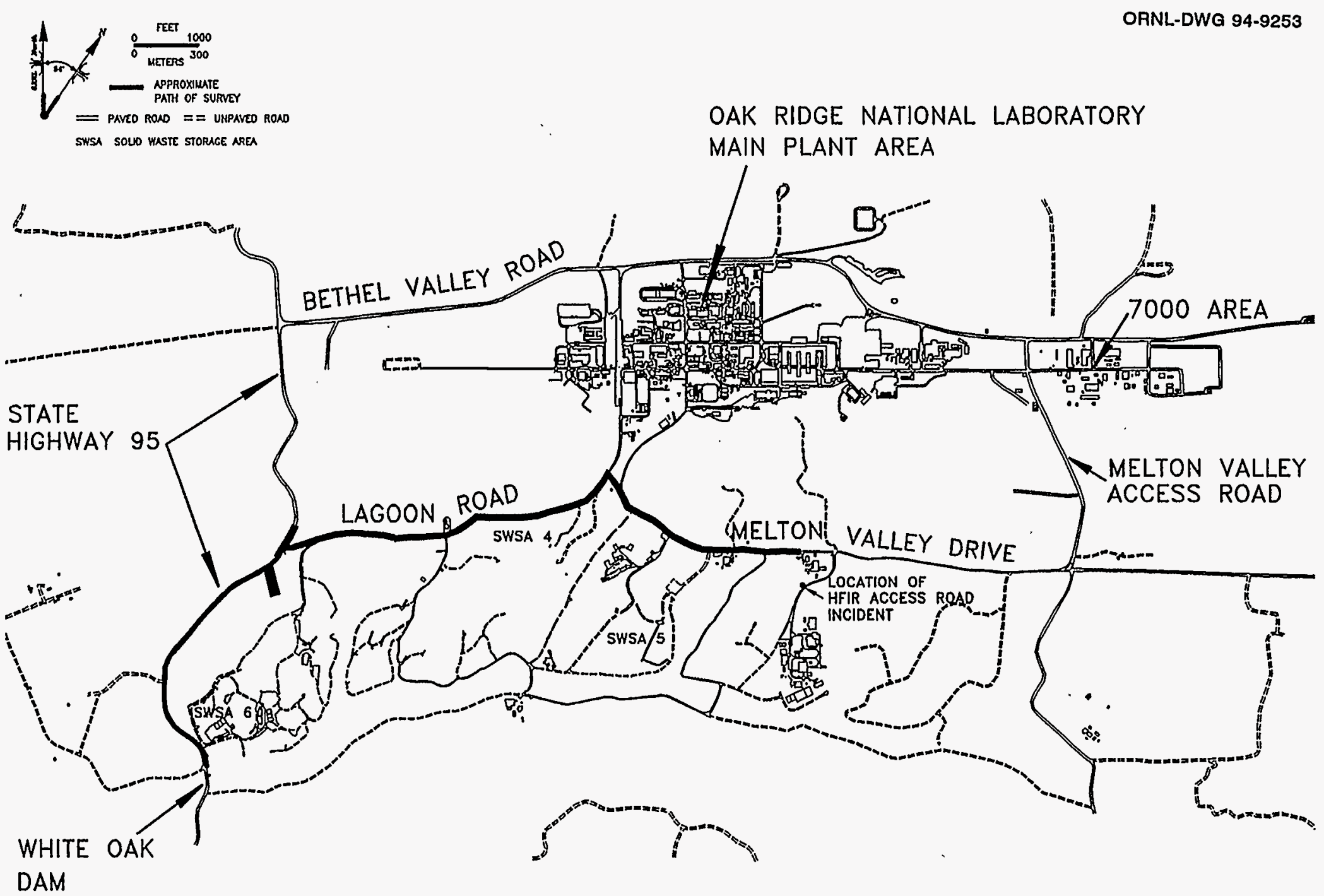

Fig. 1.1. Diagram showing general location of the survey area. A heavy line delineates the portions of State Highway 95 , Lagoon Road, and Melton Valley Drive that were surveyed. 


\section{GENERAL SURVEY METHODS AND RESULTS}

A description of typical methods and instrumentation providing guidance for the conduct of this survey is presented in Procedures Manual for the ORNL Radiological Survey Activities (RASA) Program (Myrick et al. 1987). Guidelines for the use and calibration of instruments are given in Measurement Applications and Development Group Guidelines (ORNL 1995). All direct-measurement results presented in this report are gross readings; background radiation levels have not been subtracted. Similarly, background concentrations have not been subtracted from radionuclide concentrations measured in environmental samples.

As a result of previous surveys by the ORNL Office of Radiation Protection, certain small regions within the current survey area have been designated as radiological areas and roped off to prevent access. Except for the region beneath the Tennessee Valley Authority (TVA) transmission lines, roped areas were not entered by the MAD survey team, and such areas are not delineated on drawings presented in this report.

\subsection{GAMMA RADIATION}

Surface gamma radiation was measured with a sodium iodide ( $\mathrm{NaI}$ ) scintillation probe connected to a Victoreen Model 490 Thyac III ratemeter. Because NaI gamma scintillators are energy-dependent, measurements of gamma radiation levels made with these instruments must be normalized to pressurized ionization chamber (PIC) measurements to estimate gamma exposure rates. The function developed for these conversions is

$$
y=\mathrm{CF} \times x
$$

where

$$
\begin{aligned}
y= & \text { the exposure rate }(\mu \mathrm{R} / \mathrm{h}), \\
\mathrm{CF}= & \text { the conversion factor [the slope of the regression line calculated by plotting a } \\
& \text { selected number of PIC measurements }(\mu \mathrm{R} / \mathrm{h}) \text { vs scintillation probe } \\
& \text { measurements }(\mathrm{kcpm}) \text { at the same locations], } \\
x= & \text { the scintillation probe measurements in thousand counts per minute }(\mathrm{kcpm}) .
\end{aligned}
$$

At this site, for

$$
\begin{aligned}
& x=\leq 5 \mathrm{kcpm}, \quad C F=3 ; \\
& x=>5 \text { and } s 9 \mathrm{kcpm}, \mathrm{CF}=2 ; \\
& x=>9 \text { and } \leq 13 \mathrm{kcpm} \mathrm{CF}=1.5 ; \\
& x=>13 \mathrm{kcpm}, \quad \mathrm{CF}=1 .
\end{aligned}
$$

In order to identify specific radionuclides in the field, a portable NaI gamma spectroscopy system [Personal Computer Analyzer-Portable (PCAP)] was used to perform gamma spectrum analysis at selected locations with elevated gamma radiation levels. 


\subsection{BETA-GAMMA RADIATTON}

A Bicron miniscaler/ratemeter with a Geiger-Mueller (GM) pancake detector was used to detect beta-gamma radiation. After characterization of the detectors with known beta fields (Coleman 1993), beta radiation detection levels in counts per minute were converted to dose rates in millirads per hour using the following relationship:

$$
2600 \mathrm{cpm}=1 \mathrm{mrad} / \mathrm{h} \text {. }
$$

Paved road surfaces were surveyed with the Ludlum Model 239-1F gas flow proportional detector system ("floor monitor"), which includes a Ludlum Model 2221 scaler/ratemeter connected to a Ludlum Model 43-37 detector probe mounted on a roll-around cart. The monitor was set in the beta mode (high voltage setting) where it is primarily used to detect beta radiation. At this setting the instrument is also sensitive (to a lesser extent) to alpha and gamma radiation. Anomalies detected with the floor monitor were further characterized with the GM pancake detector and the gamma scintillator; many were also smeared to determine if the contamination was transferable.

\subsection{ENVIRONMENTAL SAMPLES}

A total of 18 soil samples from 16 locations, 2 vegetation samples, and 3 water samples were collected for radionuclide analysis. Fifteen soil samples and all the vegetation and water samples were submitted to ORNL Chemical and Analytical Services Division for analysis of ${ }^{60} \mathrm{Co},{ }^{137} \mathrm{Cs}$, gross alpha, gross beta, ${ }^{40} \mathrm{~K}$, and total strontium. (Not all samples were analyzed for all radionuclides.) In addition, 8 soil samples underwent gamma spectrometry screening analysis in the MAD Group's Gamma Spectrometry Laboratory.

\subsection{PROGRESS AND PRESENTATION OF THE SURVEY}

The survey began on Melton Valley Drive and proceeded westward to the intersection with Lagoon Road, then further westward along Lagoon Road to the intersection with State Highway 95. On State Highway 95 the survey included a short section north of the Lagoon Road intersection and then preceded south to White Oak Dam (see Fig. 1.1). A small section of cleared area beneath the TVA transmission lines along State Highway 95 was also surveyed.

Survey results will be presented in reverse order from the original survey, beginning with State Highway 95 and ending with Melton Valley Drive. To facilitate graphic presentation of the data, the surveyed area has been divided into eight sections: $A, B, C, D, E, F, G$, and $H$ (see Fig. 2.1). Detailed survey results for each section are shown in Appendices $A$ and $B$. Locations of environmental samples are also indicated in Appendices A and B. The 100-ft grid established along the roads covered by this survey is included in Appendix $C$ so that data presented in Appendices A and B can be correlated with field data. Results of the analysis of environmental samples are presented in Appendix D, and site photographs are presented 
in Appendix E. A compilation of all surface survey results is shown in Plate 1. A photo of the survey crew on October 28, 1993, is shown in Fig. E.1, Appendix E. 


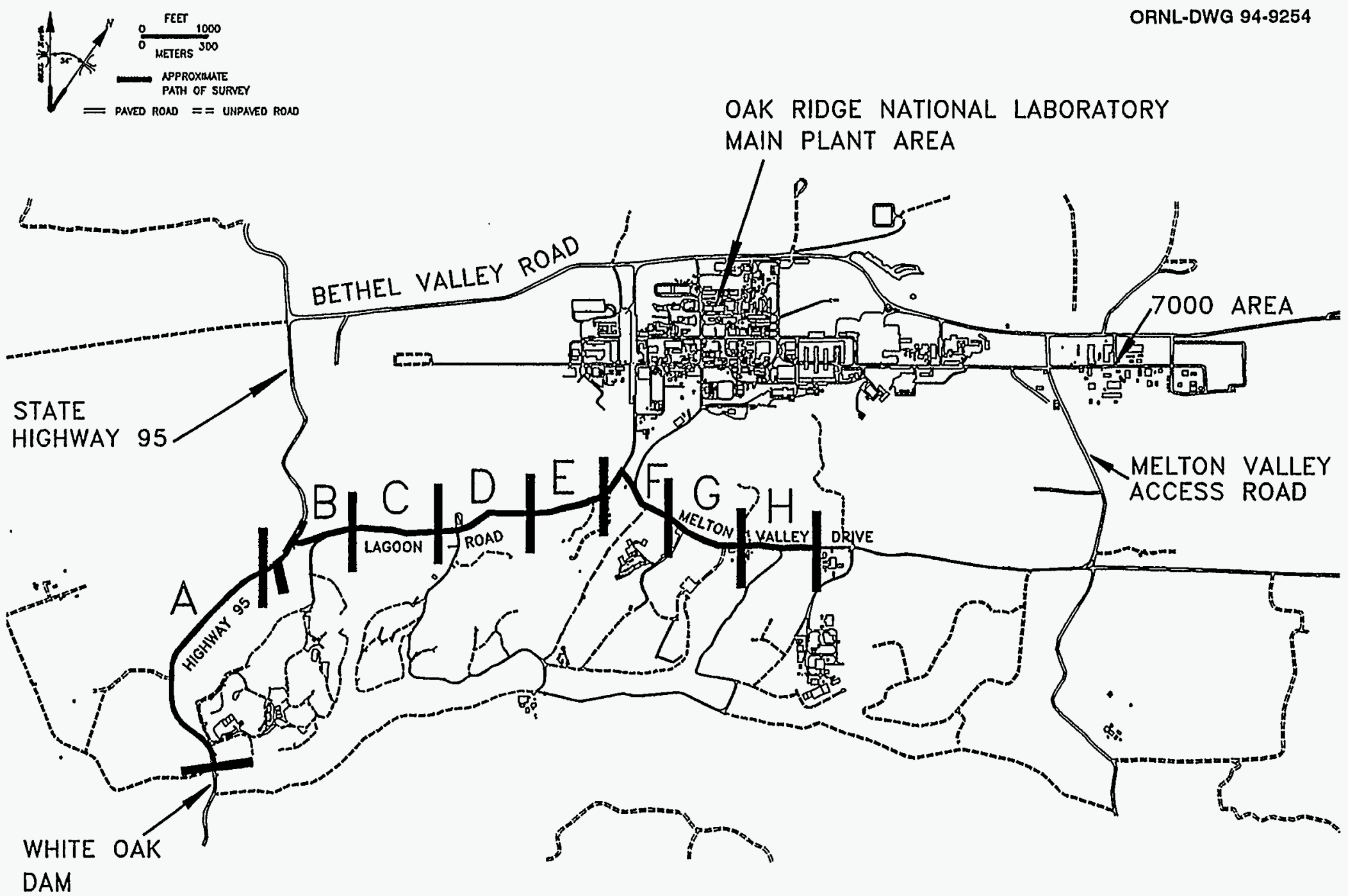

Fig. 2.1. Diagram showing division of surveyed area into Sections $A, B, C, D, E, F, G$, and $H$ to facilitate reporting of results. 


\section{SPECIFIC SURVEY METHODS AND RESULTS}

\subsection{STATE HIGHWAY 95 SOUTH OF THE LAGOON ROAD INTERSECTION}

\subsubsection{Survey Methods}

A 100-ft grid was established along the east side of State Highway 95 between White Oak Dam and the intersection of Lagoon Road. For this section of State Highway 95:

- The floor monitor was used to survey the eastern emergency lane.

- A beta-gamma scan was conducted using the GM pancake detector at spots on the road too rough to accommodate the floor monitor and on the mowed grassy border of the highway.

- Spot checks with the GM pancake detector were used in areas of higher, denser vegetation.

- A gamma scan using the gamma scintillator covered the area from the edge of the road eastward $\sim 50$ feet, including wooded areas.

\subsubsection{Survey Results Section A (Figs. A.1 and B.1)}

Gamma exposure rates (Fig. A.1) and beta-gamma dose rates (Fig. B.1) along the eastern side of State Highway 95 were within typical background levels for the area ranging from 4 to $14 \mu \mathrm{R} / \mathrm{h}$ and 0.01 to $0.03 \mathrm{mrad} / \mathrm{h}$, respectively. No elevated radiation levels were detected in the emergency lane. Except for the area under the transmission lines (see Sect. 3.2), no elevated radiation levels were detected between the edge of the road and the survey boundary $\sim 50 \mathrm{ft}$ east.

\subsection{TVA RIGHT-OF-WAY}

\subsubsection{Survey Methods}

A line (with 100-ft sections used for area estimations) was established directly along the path of the center transmission line leading southwest from the east side of State Highway 95. The survey covered a cleared area under the transmission lines measuring $-500 \mathrm{ft}$ southeast of the road by $\sim 135 \mathrm{ft}$ wide. At some of the extreme boundaries bulldozed trees and brush were piled on the ground surface preventing access. For the area surveyed:

- A surface gamma scan was conducted in accessible areas using a gamma scintillator.

- Surface beta-gamma radiation was spot checked throughout the area and scanned in areas where vegetation was close to the ground.

- A portable gamma spectroscopy system (PCAP) was used to perform gamma spectrum analysis at four locations with elevated gamma radiation levels. 


\subsubsection{Survey Results Section B (Figs. A.2 and B.2)}

A magenta and yellow rad rope (Figs. A.2 and B.2) has been erected by ORNL Office of Radiation Protection approximately $30 \mathrm{ft}$ from State Highway 95, establishing a radiological area southwest of the rope. Therefore, most of the area that was surveyed beneath the transmission lines was within this radiological area.

Background gamma exposure rates in this area ranged from 4 to $14 \mu \mathrm{R} / \mathrm{h}$; background beta-gamma dose rates ranged from 0.01 to $0.02 \mathrm{mrad} / \mathrm{h}$. Numerous scattered spots were identified with surface gamma exposure rates ranging from 15 to $67 \mu \mathrm{R} / \mathrm{h}$ (Fig. A.2) and beta-gamma dose rates ranging from 0.03 to $0.18 \mathrm{mrad} / \mathrm{h}$ (Fig. B.2). Gamma spectrum analysis at four elevated spots in this area identified the primary contaminant as ${ }^{137} \mathrm{Cs}$.

\subsection{STATE HIGHWAY 95 AT INTERSECTION WITH LAGOON ROAD}

\subsubsection{Survey Methods}

The surface gamma scan and beta-gamma spot checks were conducted on both sides of State Highway 95 from the TVA right-of-way to $-950 \mathrm{ft}$ north of the intersection with Lagoon Road. Again, a complete beta-gamma scan could only be conducted in areas with low vegetation. The survey extended from the edge of the road to the tree/brush line, usually 3 to $10 \mathrm{ft}$ east or west. Some areas on the west side of the road were inaccessible due to heavy brush. Three soil samples were collected north of the intersection of State Highway 95 with Lagoon Road.

\subsubsection{Survey Results Section B (Figs. A.2 and B.2)}

South of the Lagoon Road-State Highway 95 intersection, no elevated radiation levels were detected on either side of Highway 95, except east of the road beneath the transmission lines. North of the intersection, $\sim 15$ spots with surface gamma exposure rates (Fig. A.2) ranging from 15 to $100 \mu \mathrm{R} / \mathrm{h}$ and beta gamma dose rates (Fig. B.2) ranging from 0.06 to $0.38 \mathrm{mrad} / \mathrm{h}$ were identified 6 to $8 \mathrm{ft}$ from the east side of State Highway 95 . In addition to this cluster north of the intersection, a spot measuring $20 \mu \mathrm{R} / \mathrm{h}$ was identified on the left side of State Highway 95 and another measuring $100 \mu \mathrm{R} / \mathrm{h}$ on the east side of the highway. Identified spots with elevated radiation levels along State Highway 95 were reported to the ORNL Office of Radiation Protection and to ORNL ER Program personnel. The Office of Radiation Protection made all decisions concerning safety and remediation.

Location of the three samples (B14, B15, and B16) are shown in Figs. A.2 and B.2; results of radionuclide analysis are shown in Table D.1 (Appendix D). In all cases, the predominant radionuclide was ${ }^{137} \mathrm{Cs}$ with $1500 \pm 140 \mathrm{pCi} / \mathrm{g}$ in sample $\mathrm{B} 14,700 \pm 10 \mathrm{pCi} / \mathrm{g}$ in sample B15, and $57 \pm 3 \mathrm{pCi} / \mathrm{g}$ in sample B16. Sample B14 also contained strontium (26 \pm $4 \mathrm{pCi} / \mathrm{g}$ ). 


\subsection{LAGOON ROAD}

\subsubsection{Survey Methods}

A 100-ft grid was established along Lagoon Road from State Highway 95 to the intersection of Melton Valley Drive (Figs. C.1, C.2, C.3, C.4, and C.5). Surface and 1-m gamma exposure rates were measured at the 100 -ft grid points on both sides of Lagoon Road from the ORNL Lagoon Road security gate near State Highway 95 to the intersection of Melton Valley Drive. The road surface was surveyed with a Ludlum floor monitor, and when survey results specified gamma exposure rates associated with the road surface, the road was also surveyed with a gamma scintillator. A surface gamma scan with gamma scintillators and a surface beta-gamma spot check with GM pancakes were conducted along both sides of the road. A beta-gamma scan was conducted in areas with close-cut surface vegetation. The region surveyed generally covered the distance between the road and the bush, tree, or fence line. This distance varied from 8-30 ft near the intersection with State Highway 95 to 15 feet near the intersection with Melton Valley Drive to 3-5 feet along the SWSA 4 fence. The survey always extended at least $5 \mathrm{ft}$ from the road unless a barrier (e.g., fence) prevented access.

In addition, 9 soil samples, 3 water samples, and 1 vegetation sample were collected along Lagoon Road, and several smears were collected from paved surfaces. All were submitted for radionuclide analysis.

A 1979 survey of the waste line along Lagoon Road was presented in ORNL/TM-7858 (Ohnesorge et al. 1981) and may be of historical interest. Survey points 566 to 784 in the earlier report roughly correlate to Sects. D, E, and F of this report. The survey results cannot be directly compared because different survey methods were used.

\subsubsection{Lagoon Road Survey Results Section B (Figs. A.2 and B.2)}

Surface gamma exposure rates (Fig. A.2) were near background levels except for one elevated spot measuring $20 \mu \mathrm{R} / \mathrm{h}$ inside the security gate. Numerous spots with elevated betagamma dose rates (Fig. B.2) ranging from 0.12 to $0.88 \mathrm{mrad} / \mathrm{h}$ were located north of Lagoon Road outside the security gate. Two additional spots with surface beta-gamma levels of 0.71 and $24 \mathrm{mrad} / \mathrm{h}$ contained hot particles measuring 23 and $24 \mathrm{mrad} / \mathrm{h}$, respectively. All identified spots outside the security fence were remediated by the MAD Group. One spot $(0.10 \mathrm{mrad} / \mathrm{h})$ on the south side of Lagoon Road was identified inside the security gate. The spot was not remediated by sampling because the contamination extended deeper than the 3-in. sample depth.

An aliquot of soil sample B13 (Table D.1) collected just north of Lagoon Road (Fig. A.2) at one of the spots with a hot particle contained $200 \pm 3 \mathrm{pCi} / \mathrm{g}{ }^{137} \mathrm{Cs}$ and $760 \pm$ $30 \mathrm{pCi} / \mathrm{g}$ gross beta. Liquid scintillation analysis of the isolated particle $(-23 \mathrm{mrad} / \mathrm{h})$ determined that the beta emitters were ${ }^{137} \mathrm{Cs}$ and ${ }^{90} \mathrm{Sr}\left({ }^{137} \mathrm{Cs}, 430,000 \pm 27,000 \mathrm{pCi} / \mathrm{g}\right.$; gross beta, 7,500,000 $\pm 1,900,000 \mathrm{pCi} / \mathrm{g})$. 


\subsubsection{Lagoon Road Survey Results Section C (Figs. A.3 and B.3)}

Elevated surface gamma exposure rates (Fig. A.3) measured at five spots south of Lagoon Road and one spot north of the road ranged from 13 to $100 \mu \mathrm{R} / \mathrm{h}$; a 4 - by $70-\mathrm{ft}$ area ranged from 12 to $40 \mu \mathrm{R} / \mathrm{h}$. The 4 - by $70-\mathrm{ft}$ area extended from the edge of the road to the SWSA 4 fence, which was posted with Radiation Area signs. Beta-gamma dose rates (Fig. B.3) in the 4- by 70-ft area measured $0.12 \mathrm{mrad} / \mathrm{h}$. Additionally, beta-gamma dose rates (Fig. B.3) were elevated at two spots on the road ( 2.4 and $0.71 \mathrm{mrad} / \mathrm{h}$ ), three spots north of the road $(0.35,0.53$, and $5.2 \mathrm{mrad} / \mathrm{h})$, and 6 spots south of the road $(0.06$ to $0.87 \mathrm{mrad} / \mathrm{h}) . A$ turtle shell measured $0.08 \mathrm{mrad} / \mathrm{h}$. A caterpillar squashed on the road measured $0.07 \mathrm{mrad} / \mathrm{h}$. Seven spots, the caterpillar, and the turtle shell were remediated. The $0.53-\mathrm{mrad} / \mathrm{h}$ spot north of the road contained what appeared to be small pieces of yellow tape, which when combined measured $4.8 \mathrm{mrad} / \mathrm{h}$. No transferable contamination was associated with the $0.71-\mathrm{mrad} / \mathrm{h}$ spot on the road.

Gamma spectrometry screening analysis of sample B11 from within the $4-\times 70-\mathrm{ft}$ area showed $\sim 400 \mathrm{pCi} / \mathrm{g}$ of ${ }^{137} \mathrm{Cs}$; sample B12 contained $\sim 500,000 \mathrm{pCi} / \mathrm{g}{ }^{60} \mathrm{Co}$. All contamination at the B12 sample location was removed with sampling. Sample B17, which contained the small pieces of yellow tape, contained ${ }^{137} \mathrm{Cs}(17,000 \pm 300 \mathrm{pCi} / \mathrm{g})$, beta activity $(100,000 \pm$ $3000 \mathrm{pCi} / \mathrm{g})$, and strontium $(38,000 \pm 3000 \mathrm{pCi} / \mathrm{g})$.

\subsubsection{Lagoon Road Survey Results Section D (Figs. A.4 and B.4)}

Surface and 1-m gamma exposure rates (Fig. A.4) and general gamma scan ranges were slightly elevated toward the east end of Section $D$ because of radiation emanating from storage pits in SWSA 4. Spots of elevated surface gamma levels were found outside the fence north and east of Building $7819(60$ and $40 \mu \mathrm{R} / \mathrm{h})$ and in a natural drainage area (measuring $15 \mu \mathrm{R} / \mathrm{h}$ with spots to $40 \mu \mathrm{R} / \mathrm{h}$ ) east of Building 7819. Spots up to $40 \mu \mathrm{R} / \mathrm{h}$ were found on the ground surface near the south end of the drainage area and beneath trees along the western edge of the drainage area.

Results of the beta-gamma survey are shown in Fig. B.4. A large region containing contaminated trees with beta-gamma dose rates up to $1.1 \mathrm{mrad} / \mathrm{h}$ and leaves up to $0.12 \mathrm{mrad} / \mathrm{h}$ was located west of Building 7819. The region of trees was about $125 \mathrm{ft}$ wide at the widest point. Approximately 25 trees were marked with yellow tape, and the ORNL Office of Radiation Protection was notified. A tree branch taken from a tree measuring $1.06 \mathrm{mrad} / \mathrm{h}$ (V2, Table D.1)) contained primarily strontium $(211 \pm 3 \mathrm{pCi} / \mathrm{g})$ and some ${ }^{137} \mathrm{Cs}(8 \pm 1 \mathrm{pCi} / \mathrm{g})$. Elevated spots on Lagoon Road just west of Building 7819 measured 1.5 and $5.3 \mathrm{mrad} / \mathrm{h}$; spots on the road south of Building 7819 measured 0.10 to $0.60 \mathrm{mrad} / \mathrm{h}$.

Discarded metal debris stacked outside the fence northeast of Building 7819 was spot checked and found to have beta-gamma levels up to $0.19 \mathrm{mrad} / \mathrm{h}$. ORNL Radiation Protection personnel were notified. Most of the metal was covered with leaves and soil.

Another region containing $\sim 40$ contaminated trees was located around a natural drainage area (Figs. B.4 and E.2). The contaminated trees generally followed the path of contaminated soil beginning at the fenced gravel area behind Building 7819 and continuing down the 
drainage area. Beta-gamma dose rates measured on contact with tree bark ranged from 0.04 to $0.72 \mathrm{mrad} / \mathrm{h}$; beta-gamma dose rates of the ground surface beneath the trees ranged from 0.04 to $0.12 \mathrm{mrad} / \mathrm{h}$. Surface levels in the drainage area ranged from 0.03 to $0.12 \mathrm{mrad} / \mathrm{h}$. Leaves $(1.2 \mathrm{mrad} / \mathrm{h})$ from the contaminated trees were found on a grating (Fig. E.3) at the south end of the drainage area, the bank to the east $(0.04$ to $0.58 \mathrm{mrad} / \mathrm{h})$, and the south side of Lagoon Road ( 0.08 to $0.15 \mathrm{mrad})$. Contaminated leaves were removed for disposal.

Details of the bank to the east of the drainage area are shown in Figs. B.5 and E.4. A portion of the bank had been covered with asphalt. Parts of the bank measured up to $0.92 \mathrm{mrad} / \mathrm{h}$, leaves up to $0.58 \mathrm{mrad} / \mathrm{h}$, and the blacktop surface up to $0.38 \mathrm{mrad} / \mathrm{h}$. Transferable beta-gamma radiation $(0.15 \mathrm{mrad} / \mathrm{h})$ was found on the asphalt beside the road in this area (Fig. E.5). Contaminated leaves in this area were remediated on both sides of the road.

Three water samples (W1, W2, and W3; Fig. B.4 and Table D.1) were collected in this area, which is part of the White Oak Creek watershed. Sample W1, taken as water entered a culvert near leaves measuring $1.2 \mathrm{mrad} / \mathrm{h}$, contained elevated beta activity $(2700 \pm$ $270 \mathrm{pCi} / \mathrm{L})$ and strontium $(1400 \pm 80 \mathrm{pCi} / \mathrm{L})$. Sample $\mathrm{W} 2$, collected from a puddle of water standing on asphalt near a dry area measuring $0.38 \mathrm{mrad} / \mathrm{h}$, contained elevated ${ }^{137} \mathrm{Cs}(51 \pm$ $5 \mathrm{pCi} / \mathrm{L})$, beta activity $(35,000 \pm 2700 \mathrm{pCi} / \mathrm{L})$, and strontium $(20,000 \pm 540 \mathrm{pCi} / \mathrm{L})$. Sample W3, collected from standing water, at the bottom of the drainage area, contained elevated beta activity $(81 \pm 8 \mathrm{pCi} / \mathrm{L})$.

Soil samples (Fig. B.4, Table D.1) B6 and B10, taken at the same general location, contained elevated beta activity ( $24 \pm 2$ and $320 \pm 30 \mathrm{pCi} / \mathrm{g}$, respectively) and strontium (10 \pm 2 and $150 \pm 5 \mathrm{pCi} / \mathrm{g}$, respectively); sample B10 also contained ${ }^{137} \mathrm{Cs}(21 \pm 1 \mathrm{pCi} / \mathrm{g})$. Soil sample B7, consisting of sediment and debris from the bottom of the drainage area, contained ${ }^{137} \mathrm{Cs}(7.6 \pm 0.3 \mathrm{pCi} / \mathrm{g})$ and elevated beta activity $(130 \pm 5)$; the sample was not analyzed for strontium.

\subsubsection{Lagoon Road Survey Results Section E (Fig. A.5 and B.6)}

Before the scheduled surface survey in this area, a preliminary spot-check investigation was requested along Lagoon Road in the region of SWSA 4 where a guard rail was being installed. Gamma and beta-gamma spot checks revealed no contamination associated with the installation work although some guard rail support posts were placed within 2 in. of old waste pit caps. However, a small area with elevated beta-gamma levels (Sample B5, discussed below) was found between the SWSA 4 fence and the newly installed guard rail during this preliminary spot-check survey.

Radiation emanating from SWSA 4, located directly south of Lagoon Road in Section E, elevated all surface and 1-m gamma exposure rates measured at $100-\mathrm{ft}$ intervals and all gamma scan ranges on and beside the road (Fig. A.5). Under such conditions, surface contamination measuring less than the elevated background gamma radiation levels ( 15 to $62 \mathrm{mR} / \mathrm{h}$ ) cannot be detected. Hot spots that could be detected included two pits covered with grating, which measured 80 and $300 \mu \mathrm{R} / \mathrm{h}$, and three areas at the eastern end of this section, which measured 100,100 , and $150 \mu \mathrm{R} / \mathrm{h}$ at the surface. 
In addition to the two soil sample locations discussed below, elevated surface beta-gamma levels (Fig. B.6) were associated with two snails ( 0.31 and $0.44 \mathrm{mrad} / \mathrm{h})$, a root $(0.38 \mathrm{mrad} / \mathrm{h})$, a $6-\times 3-\mathrm{ft}$ area $(0.23 \mathrm{mrad} / \mathrm{h})$, a $4-\times 4-\mathrm{ft}$ area $(0.71 \mathrm{mrad} / \mathrm{h})$, a $2-\times 2-\mathrm{ft}$ area $(0.52 \mathrm{mrad} / \mathrm{h})$, a 3- by 3-ft area (with a clump of dead grass measuring up to $1.5 \mathrm{mrad} / \mathrm{h}$ ), 2 spots south of the road $(0.11$ to $0.16 \mathrm{mrad} / \mathrm{h})$, and 5 spots on the road $(0.05$ to $6.76 \mathrm{mrad} / \mathrm{h})$. A smear sample collected at the $6.76-\mathrm{mrad} / \mathrm{h}$ spot, which was $<15 \mathrm{~cm}^{2}$, showed no removable activity.

Soil sample B9 collected at a spot measuring $\sim 12 \mathrm{mrad} / \mathrm{h}$ and $15 \mathrm{mR} / \mathrm{h}$ at the surface and $2 \mathrm{mR} / \mathrm{h}$ at $1 \mathrm{~m}$ contained $10,000 \pm 300 \mathrm{pCi} / \mathrm{g}{ }^{137} \mathrm{Cs}$ and $43 \pm 8 \mathrm{pCi} / \mathrm{g}{ }^{90} \mathrm{Sr}$. Although this area is outside the SWSA 4 fence, it is behind the recently installed guard rails and, therefore, is not likely to result in contamination of vehicles. Sample B5, collected in a high background radiation area by the SWSA 4 guardrail at a spot measuring $0.54 \mathrm{mrad} / \mathrm{h}$ and $60 \mu \mathrm{R} / \mathrm{h}$ at the surface and $50 \mu \mathrm{R} / \mathrm{h}$ at $1 \mathrm{~m}$, also contained ${ }^{137} \mathrm{Cs}(430 \pm 30 \mathrm{pCi} / \mathrm{g})$.

\subsubsection{Lagoon Road Survey Results Section F (Figs. A.6 and B.7)}

Background gamma exposure rates in this area ranged from 25 to $80 \mu \mathrm{R} / \mathrm{h}$ (Fig. A.6) due to radiation emanating from the White Oak Creek floodplain and various roped radiological areas. East of Lagoon Road near the intersection with Melton Valley Drive, four sizable ground surface areas were identified with elevated gamma exposure rates $(200,400,100$ to 200 , and 200 to $500 \mu \mathrm{R} / \mathrm{h}$, Fig. A.6) and elevated beta-gamma dose rates $(0.15,0.08$ to 0.38 , 0.08 to 0.19 , and 0.38 to $0.96 \mathrm{mrad} / \mathrm{h}$, Fig. B.7). The three larger (northern most) of the four areas extended beyond the survey area, probably to White Oak Creek. A small spot measuring $12 \mathrm{mrad} / \mathrm{h}$ (Fig. B.7) and $50 \mu \mathrm{R} / \mathrm{h}$ at the surface and $55 \mu \mathrm{R} / \mathrm{h}$ at $1 \mathrm{~m}$ (Fig. A.6) was sampled and remediated.

West of Lagoon Road, a 20-mrad/h spot (Fig. B.7) containing a single hot particle $(60 \mathrm{mrad} / \mathrm{h})$ attached to a blade of decayed grass, was remediated by sampling. Other elevated radiation levels west of Lagoon Road in Section F included a metal culvert (150 to $200 \mu \mathrm{R} / \mathrm{h}$ and 0.15 to $0.23 \mathrm{mrad} / \mathrm{h})$, a willow tree $(0.3 \mathrm{mrad} / \mathrm{h}$, Fig. E.6), a $2-$ by $2-\mathrm{ft}$ area (160 to $180 \mu \mathrm{R} / \mathrm{h}$ and $0.08 \mathrm{mrad} / \mathrm{h}$ ), and numerous spots (25 to $180 \mu \mathrm{R} / \mathrm{h}$ and $0.80 \mathrm{mrad} / \mathrm{h}$ ). The numerous spots measuring up to $0.8 \mathrm{mrad} / \mathrm{h}$ near the road were reported to ORNL Office of Radiation Protection. A region of contamination $\left(-2 \mathrm{ft}^{2}\right)$ extended outside the boundary of a posted 6- by 18-ft Radiation Area containing contaminated pits (Fig. E.7). Beta-gamma levels on the ground outside the rope ranged up to $0.15 \mathrm{mrad} / \mathrm{h}$.

Soil sample B8 collected east of Lagoon Road in this area contained ${ }^{137} \mathrm{Cs}(2000 \pm$ $40 \mathrm{pCi} / \mathrm{g})$ and some ${ }^{60} \mathrm{Co}(4.7 \pm 0.4 \mathrm{pCi} / \mathrm{g})$ (Table D.1).

\subsection{MELTON VALLEY DRIVE}

\subsubsection{Survey Methods}

A 100-ft grid was established along Melton Valley Drive from the intersection with Lagoon Road to the point where the waste line crosses Melton Valley Drive near Building 7567 (Figs. C.5, C.6, and C.7). Surface and 1-m gamma exposure rates were 
measured at the 100-ft grid points near the Lagoon Road intersection and at other selected points. The road surface was surveyed with the Ludlum floor monitor, and when survey results specify gamma exposure rates associated with the road surface, the road was also surveyed with the gamma scintillator. A surface gamma scan with the gamma scintillator and a surface beta-gamma spot check with the GM pancake (or a beta-gamma scan in areas with close-cut vegetation) was conducted along both sides of the road west of the SWSA 5 Access Road and along the north side of the road east of the access road. The area surveyed generally extended at least $3 \mathrm{ft}$ north (or south, if the waste line was on the south side of Melton Valley Drive) of the waste line and included the area between the waste line and the road.

In addition, 4 soil samples and 1 vegetation sample were collected along Melton Valley Drive, and several smear samples were collected from paved surfaces. All were submitted for radionuclide analysis.

\subsubsection{Melton Valley Drive Survey Results Section F (Figs. A.6 and B.7)}

Background gamma exposure rates were elevated at the western end of Melton Valley Drive (Fig. A.6) due to radiation emanating from a radiological area south of the road and from the contaminated White Oak Creek floodplain areas. The elevated gamma exposure rates ranged from 40 to $70 \mu \mathrm{R} / \mathrm{h}$ along the south side of Melton Valley Drive and from 60 to $200 \mu \mathrm{R} / \mathrm{h}$ south of Building 7875. In this area, surface hot spots below these levels could not be detected because of the high background levels. Three spots with elevated gamma levels (70, 100, and $300 \mu \mathrm{R} / \mathrm{h}$, Fig. A.6) were found near Building 7875; two spots with elevated gamma levels ( 27 and $25 \mu \mathrm{R} / \mathrm{h}$ ) were located toward the eastern side of Section $\mathrm{F}$.

Beta-gamma dose rates were elevated at two spots north and two spots south of Melton Valley Drive near Building 7875 (0.08 to $0.82 \mathrm{mrad} / \mathrm{h}$, Fig. B.7) and at two spots on the road surface (0.27 and $0.38 \mathrm{mrad} / \mathrm{h})$. A smear at the $0.38-\mathrm{mrad} / \mathrm{h}$ spot on the road indicated no transferable contamination.

A cluster of four or five samples of beta-gamma contaminated material thought to be deer droppings were found north of Melton Valley Drive. One sample was analyzed and found to contain a mixture of ${ }^{137} \mathrm{Cs}(30 \mathrm{pCi} / \mathrm{g})$ and Sr. Soil sample B4 (sample depth 3 to 6 in., Table D.1) contained ${ }^{60} \mathrm{Co}(4.0 \pm 0.3 \mathrm{pCi} / \mathrm{g}),{ }^{137} \mathrm{Cs}(950 \pm 30 \mathrm{pCi} / \mathrm{g})$, elevated alpha activity $(27 \pm 0.3 \mathrm{pCi} / \mathrm{g})$, and elevated beta activity $(730 \pm 50 \mathrm{pCi} / \mathrm{g})$. Soil sample B3 (sample depth 0 to 2 in.) contained ${ }^{137} \mathrm{Cs}(320 \pm 30 \mathrm{pCi} / \mathrm{g})$ and elevated beta activity $(260 \pm 20 \mathrm{pCi} / \mathrm{g})$.

\subsubsection{Melton Valley Drive Survey Results Section G (Figs. A.7 and B.8)}

Surface gamma anomalies (Fig. A.7) south of Melton Valley Drive included a spot $(100 \mu \mathrm{R} / \mathrm{h})$, a $2-$ by 4 -ft area $(15$ to $30 \mu \mathrm{R} / \mathrm{h})$, a corrugated pipe $(130 \mu \mathrm{R} / \mathrm{h})$, and another small area $(90 \mu \mathrm{R} / \mathrm{h})$. One gamma anomaly north of Melton Valley Drive measured $4500 \mu \mathrm{R} / \mathrm{h}$ at the surface and $35 \mu \mathrm{R} / \mathrm{h}$ at $1 \mathrm{~m}$. Gamma spectrum analysis with the PCAP indicated $-250,000 \mathrm{pCi} / \mathrm{g}{ }^{137} \mathrm{Cs}$. ORNL Radiation Protection personnel were notified of this area located $\sim 35 \mathrm{ft}$ north of the road. 
Surface beta-gamma anomalies (Fig. B.8) south of Melton Valley Drive included a corrugated pipe $(0.20 \mathrm{mrad} / \mathrm{h})$, a 3 - by $9-\mathrm{ft}$ area $(0.06$ to $1.5 \mathrm{mrad} / \mathrm{h})$, a 12 - by $43-\mathrm{ft}$ area $(0.08$ to $0.95 \mathrm{mrad} / \mathrm{h})$, and a spot $(0.18 \mathrm{mrad} / \mathrm{h})$. The 3- by 9 -ft area with beta-gamma levels up to $1.5 \mathrm{mrad} / \mathrm{h}$ was directly adjacent to Melton Valley Drive, but a guard rail prevents vehicle access from the road. Anomalies on the road surface, all located at the intersection with the SWSA 5 Access Road, included two spots $(0.8$ and $0.68 \mathrm{mrad} / \mathrm{h})$ and a cluster of -16 spots ( 0.5 to $1.0 \mathrm{mrad} / \mathrm{h}$, Fig. E.8). The cluster covered a $\sim 4$ by $1.5-\mathrm{m}$ area with radiation measurements on contact with the road surface reaching $16,000 \mathrm{dpm} / 100 \mathrm{~cm}^{2}$. Smear samples taken at four spots having the highest dose rates indicated no transferable contamination. No elevated gamma radiation levels were associated with the spots on the road. Beta-gamma anomalies north of Melton Valley Drive included an animal bone $(0.06 \mathrm{mrad} / \mathrm{h})$, a ground surface area $\left(11.5 \mathrm{mrad} / \mathrm{h},-250,000 \mathrm{pCi} / \mathrm{g}{ }^{137} \mathrm{Cs}\right)$, a spot $(0.23 \mathrm{mrad} / \mathrm{h})$, a $4-\mathrm{m}^{2}$ area with numerous spots up to $0.20 \mathrm{mrad} / \mathrm{h}$ under a sweet gum tree, $\mathrm{a} \cdot 1-\mathrm{m}^{2}$ area $(0.07$ to 0.78$)$, and a willow tree $(0.08 \mathrm{mrad} / \mathrm{h})$. As mentioned earlier, ORNL Radiation Protection personnel were notified about the $11.5-\mathrm{mrad} / \mathrm{h}$ spot.

All gamma and beta-gamma anomalies in Section $G$ except the animal bone, the $0.18-\mathrm{mrad} / \mathrm{h}(90 \mu \mathrm{R} / \mathrm{h})$ spot, and the spots on the road surface were located along the path of the LLW.

\subsubsection{Melton Valley Drive Survey Results Section H (Figs. A.8 and B.9)}

Surface gamma anomalies (Fig. A.8) north of Melton Valley Drive included a spot $(60 \mu \mathrm{R} / \mathrm{h}$ at the surface and $20 \mu \mathrm{R} / \mathrm{h}$ at $1 \mathrm{~m})$, another spot $(20 \mu \mathrm{R} / \mathrm{h})$ and a cluster of spots $(12$ to $23 \mu \mathrm{R} / \mathrm{h})$. Two anomalies on the road surface measured 10 and $16 \mu \mathrm{R} / \mathrm{h}$. All anomalies north of Melton Valley Drive were in the vicinity of the waste line.

Beta-gamma dose rates (Fig. B.9) north of Melton Valley Drive were greatly increased by a previously remediated waste line leak site (SWMU 8.3g). The area of the former leak site was divided into 22 sections where $\sim 450$ trees and shrubs were spot-checked for betagamma radiation. Two sections were not surveyed because of high surface ( 0.08 to $3.3 \mathrm{mrad} / \mathrm{h})$ and $1-\mathrm{m}(0.08$ to $0.19 \mathrm{mrad} / \mathrm{h})$ beta-gamma dose rates. ${ }^{2}$ In the other 20 sections, -20 trees with elevated beta-gamma levels were marked with orange tape. ORNL Radiation Protection was notified and a Contamination Area rope was erected to enclose all contaminated vegetation (Fig. E.9). Later the Contamination Area rope was extended westward to enclose the contaminated drainage ditch (see below). The beta-gamma survey was extended to cover a swath $\sim 15 \mathrm{ft}$ north of the rope where general background beta-gamma levels ranged from 0.01 to $0.03 \mathrm{mrad} / \mathrm{h}$ and one anomaly measuring $0.07 \mathrm{mrad} / \mathrm{h}$ was flagged. The survey also included the area between the rope and Melton Valley Drive.

Surface beta-gamma anomalies (Fig. B.9) in the vicinity of the waste line included a spot $(0.16 \mathrm{mrad} / \mathrm{h})$, an elevated drainage ditch $(0.49 \mathrm{mrad} / \mathrm{h})$, a $4-\mathrm{ft}^{2}$ area $(0.77$ to $3.1 \mathrm{mrad} / \mathrm{h})$, a

\footnotetext{
${ }^{2} \mathrm{~A}$ high beta-gamma radiation field over a relatively large area made it impossible to obtain accurate measurements for individual trees. General beta-gamma dose rates were determined on the ground surface, at $1 \mathrm{~m}$, and on contact with some of the hottest trees. As soon as this was accomplished, the survey was discontinued to avoid unnecessary exposure to the survey crew.
} 
tree $(0.19$ to $0.31 \mathrm{mrad} / \mathrm{h})$, a sizable stand of trees $(0.08$ to $3.8 \mathrm{mrad} / \mathrm{h})$, a live caterpillar on a leaf $(0.12 \mathrm{mrad} / \mathrm{h})$, the ground surface under the trees $(0.08$ to $3.3 \mathrm{mrad} / \mathrm{h})$, a sweet gum tree $(0.08$ to $0.25 \mathrm{mrad} / \mathrm{h})$, leaves under the sweet gum tree $(0.06$ to $0.23 \mathrm{mrad} / \mathrm{h})$, and a 10 by 15 -ft area $(0.06$ to $1.5 \mathrm{mrad} / \mathrm{h})$. Two spots $(0.09$ and $0.49 \mathrm{mrad} / \mathrm{h})$ were located on the edge of Melton Valley Drive. Activity at the $0.49-\mathrm{mrad} / \mathrm{h}$ spot was attributed to a chip of paint $(>7.7 \mathrm{mrad} / \mathrm{h})$, which was easily remediated. Anomalies located on the road surface included a spot near Building $7505(1.9 \mathrm{mrad} / \mathrm{h})$, a spot near monitoring well $1031(0.50 \mathrm{mrad} / \mathrm{h})$, and a spot near Building $7567(0.30 \mathrm{mrad} / \mathrm{h})$. A smear at the $0.50-\mathrm{mrad} / \mathrm{h}$ spot indicated no transferable contamination. Analysis of the $0.30-\mathrm{mrad} / \mathrm{h}$ spot with the PCAP showed the presence of ${ }^{60} \mathrm{Co}$.

Vegetation sample V1 consisting of several dead tree branches collected in a 10-by $15-\mathrm{ft}$ area measuring 0.06 to $1.5 \mathrm{mrad} / \mathrm{h}$ contained elevated beta activity $(1900 \pm 30 \mathrm{pCi} / \mathrm{g})$, which probably indicates the presence of strontium concentrated by the living trees. Soil sample B1 and B2 taken 3 to $4 \mathrm{ft}$ from the road contained ${ }^{137} \mathrm{Cs}$ and elevated beta activity. Sample B1 contained $26 \pm 1 \mathrm{pCi} / \mathrm{g}{ }^{137} \mathrm{Cs}$ and $70 \pm 10 \mathrm{pCi} / \mathrm{g}$ gross beta. Sample B2 contained $9.6 \pm$ $0.4 \mathrm{pCi} / \mathrm{g}{ }^{137} \mathrm{Cs}$ and $80 \pm 10 \mathrm{pCi} / \mathrm{g}$ gross beta. All sample results are given in Table D.1. 


\section{SIGNIFICANCE OF FINDINGS}

\subsection{STATE HIGHWAY 95}

No elevated gamma exposure rates or beta-gamma dose rates were detected in the east emergency lane of State Highway 95 between the Lagoon Road intersection and White Oak Dam. Except for the area beneath the transmission lines, no elevated gamma or beta-gamma levels were detected between the edge of the road and the survey boundary $\sim 50 \mathrm{ft}$ east.

Immediately north of the intersection of State Highway 95 with Lagoon Road, -15 spots with elevated gamma exposure rates (15 to $100 \mu \mathrm{R} / \mathrm{h}$ ) and elevated beta-gamma dose rates $(0.06$ to $0.38 \mathrm{mrad} / \mathrm{h})$ were identified 6 to $8 \mathrm{ft}$ from the east side of the road. One spot with elevated gamma activity $(20 \mu \mathrm{R} / \mathrm{h})$ was detected on the west side of State Highway 95 and one spot $(100 \mu \mathrm{R} / \mathrm{h}) \sim 450 \mathrm{ft}$ north of the intersection on the east side. No other elevated radiation levels were detected up to $950 \mathrm{ft}$ north of the intersection. Cesium-137 was the predominant radionuclide in three soil samples collected along State Highway 95; one sample also contained ${ }^{90} \mathrm{Sr}$. All elevated radiation levels along State Highway 95 were reported to the ORNL Office of Radiation Protection, which took responsibility for remedial actions in this area. Approximately $72 \mathrm{ft}^{3}$ of contaminated soil was excavated and removed from this area to SWSA 6.

\subsection{TVA RIGHT-OF-WAY}

A roped radiological area extending $\sim 500 \mathrm{ft}$ southeast of State Highway 95 in the cleared area beneath the transmission lines contained numerous scattered spots with elevated surface gamma exposure rates $(14 \text { to } 67 \mu \mathrm{R} / \mathrm{h})^{3}$ and beta-gamma dose rates $(0.04 \text { to } 0.18 \mathrm{mrad} / \mathrm{h})^{3}$. Two spots were detected outside the magenta and yellow rad rope near State Highway 95. Cesium-137 was the primary contaminant both inside and outside the rad rope.

\subsection{LAGOON ROAD}

At the western end of Lagoon Road between State Highway 95 and the ORNL Security Gate, numerous spots with elevated beta-gamma dose rates were identified north of the road. Two of the spots contained hot particles measuring 23 and $24 \mathrm{mrad} / \mathrm{h}$; beta emitters were ${ }^{137} \mathrm{Cs}$ and ${ }^{90} \mathrm{Sr}$. All spots in this area were remediated by the ORNL MAD group.

East of the security gate, numerous spots and areas of elevated gamma and beta-gamma radiation levels were identified both north and south of Lagoon Road and on the road surface. No transferable radioactivity was found on the road surface. Cesium-137 was the primary contaminant in sampled soil along Lagoon Road; one sample contained ${ }^{60} \mathrm{Co}$.

\footnotetext{
${ }^{3}$ Typical background surface gamma exposure rates in this area ranged from 4 to $14 \mu \mathrm{R} / \mathrm{h}$ and beta-gamma dose rates ranged from 0.01 to $0.03 \mathrm{mrad} / \mathrm{h}$.
} 
Highlights of the survey along Lagoon Road follow.

1. A $\sim 12,000-\mathrm{ft}^{2}$ area west of Building 7819 contained -25 trees with elevated beta-gamma dose rates on tree trunks measuring up to $1.1 \mathrm{mrad} / \mathrm{h}$ and leaves measuring up to $0.12 \mathrm{mrad} / \mathrm{h}$. Analysis of a tree branch identified strontium as the primary contaminant along with some ${ }^{137} \mathrm{Cs}$.

2. An area east of Building 7819 along a natural drainage gully contained $\sim 40$ trees with elevated beta-gamma dose rates ranging from 0.04 to $0.72 \mathrm{mrad} / \mathrm{h}$. The ground surface under the trees ranged from 0.04 to $0.12 \mathrm{mrad} / \mathrm{h}$. Leaves ranging from 0.08 to $1.2 \mathrm{mrad} / \mathrm{h}$ were scattered along both sides of the road. Water and soil samples from the area contained primarily strontium and some ${ }^{137} \mathrm{Cs}$.

3. Radiation emanating from SWSA 4, located directly south of Lagoon Road, greatly enhanced surface and 1-m gamma exposure rates, therefore masking low-level gamma anomalies that might be in this area. One spot detected outside the SWSA 4 fence, but behind the recently installed guardrail, measured $\sim 12 \mathrm{mrad} / \mathrm{h}$ and $15 \mathrm{mR} / \mathrm{h}$ at the surface and $2 \mathrm{mR} / \mathrm{h}$ at $1 \mathrm{~m}$. The primary contaminant was ${ }^{137} \mathrm{Cs}$.

4. Near the Lagoon Road intersection with Melton Valley Drive, background gamma exposure rates were elevated due to various roped radiological areas in the region and radiation emanating from the White Oak Creek floodplain. Three wide-spreading areas of contamination, which apparently extended all the way to White Oak Creek, were identified east of Lagoon Road. Cesium-137 was the primary contaminant in a soil sample collected near the northernmost contaminated area.

5. Animal and plant life offer further evidence that the environment along Lagoon Road is contaminated. Elevated beta-gamma dose rates were noted in a turtle shell, a caterpillar squashed on the road, three snails beside the road, a root, and numerous leaves and twigs scattered along the roadside, and two stands of trees.

\subsection{MELTON VALLEY DRIVE}

Again, numerous spots and areas of elevated gamma and beta-gamma radiation levels were identified both north and south of Melton Valley Drive and on the road surface. No transferable radioactivity was found on the road surface.

Highlights of the Melton Valley Drive survey follow.

1. A 12- by 43-ft area south of Melton Valley Drive and west of the SWSA 5 Access Road contained numerous anomalies measuring 0.08 to $0.95 \mathrm{mrad} / \mathrm{h}$ (Fig. E.10). Fortunately, this area was protected from roadside traffic by a guard rail. Other areas along Melton Valley Drive (Figs. E.11 and E.12) were adjacent to the pavement, and therefore, possibly subject to vehicle traffic.

2. A spot north of Melton Valley Drive also near the SWSA 5 Access Road measured $11.5 \mathrm{mrad} / \mathrm{h}$ and $4500 \mu \mathrm{R} / \mathrm{h}$ at the surface and $35 \mu \mathrm{R} / \mathrm{h}$ at $1 \mathrm{~m}$. Gamma spectrometry 
screening analysis of the entire sample volume demonstrated the presence of $250,000 \mathrm{pCi} / \mathrm{g}$ of ${ }^{137} \mathrm{Cs}$.

3. Animal and plant life reflect the state of the environment along Melton Valley Drive. Deer droppings, an animal bone, a sweet gum tree, a willow tree, a caterpillar, and the large area of trees discussed below exhibited elevated beta-gamma activity.

4. Because past cleanup efforts were not totally successful, a large group of trees growing at the site of a previously remediated waste line leak showed high levels of beta activity. The trees were divided into 22 sections where -450 trees and shrubs were spot-checked for elevated beta-gamma activity. One section with high surface (up to $3.3 \mathrm{mrad} / \mathrm{h}$ ) and 1-m (up to $0.19 \mathrm{mrad} / \mathrm{h}$ ) beta-gamma dose rates was not surveyed to avoid unnecessary exposure to the survey crew. Approximately 20 trees with elevated beta-gamma dose rates were marked in the remaining 21 sections. The entire area was enclosed within a Contamination Area by ORNL Radiation Protection. A vegetation sample from the area exhibited elevated beta activity, which probably indicates the presence of strontium. Strontium is readily taken up by plants, particularly in areas with low calcium concentrations in the soil.

\subsection{REMEDIATION ACTTVITIES}

Approximately $50 \%$ of the elevated spots that were identified in soil were remediated by sampling. Using the most conservative approach, ORNL MAD considered all soil contamination to be transferable. According to ORNL Health Physics Procedure (ORNL 1991), transferable beta-gamma contamination $>2000 \mathrm{dpm} / 100 \mathrm{~cm}^{2}$ requires that a Controlled Area designation be changed to a Contamination Area designation. Therefore, the ORNL MAD Group survey crew reported all unremediated spots and areas with surface soil beta-gamma measurements $>2000 \mathrm{dpm} / 100 \mathrm{~cm}^{2}$ to the ORNL Office of Radiation Protection (ORP), which was responsible for remediation, roping, or whatever ORP judged to be appropriate. Similarly, following guidelines established by Martin Marietta Energy Systems, Inc., for the posting and control of environmental soil contamination areas, all spots with ${ }^{137} \mathrm{Cs}$ concentrations $>30 \mathrm{pCi} / \mathrm{g}$ and ${ }^{90} \mathrm{Sr}$ concentrations $>40 \mathrm{pCi} / \mathrm{g}$ that were not remediated by sampling were reported to the ORNL Office of Radiation Protection.

In addition, contaminated leaves along the road were removed for disposal. Although areas with contaminated trees have been roped off, the vegetation continues to take up strontium from the soil. Contaminated tree leaves, which are not confined by the rope, will continue to be deposited on the ground surface and distributed throughout the area. 


\section{RECOMMENDATIONS}

The presence of above-background surface radiation measurements and concentrations of beta- and beta-gamma emitting radionuclides along sections of State Highway 95, Lagoon Road, and Melton Valley Drive warrant corrective measures. We recommend, at minimum, the following:

- A systematic surface beta-radiation scan of Melton Valley.

- A comprehensive risk assessment of potential exposures to the public.

- Interim corrective measures, including isolation of contaminated areas; minimization of dispersion and redistribution of fugitive radionuclides; removal, treatment, and disposal of certain contaminated media; and closure of Lagoon Road.

These recommendations are briefly discussed below.

\subsection{SYSTEMATIC SURFACE BETA-RADIATION SCAN OF MELTON VALLEY}

Contamination of Melton Valley and, in particular, areas near Lagoon Road should be fully characterized. The surface radiological survey revealed ground surface "hot" spots (or particles) and radioactively contaminated trees adjacent to and in very close proximity to Lagoon Road and Melton Valley Drive. Elevated concentrations of ${ }^{90} \mathrm{Sr}$ and ${ }^{137} \mathrm{Cs}$ were demonstrated by laboratory analysis of selected environmental samples. Additionally, historical accounts (Lomenick and Cowser 1961) suggest that approximately 50 auger holes were used to dispose of small packages of higher-level waste and for temporary storage of recoverable materials contaminated with fission products of short half life. The auger holes were reportedly located in the northern part of SWSA 4. A visual inspection of this area located about 20 auger holes. However, several were found on the south shoulder of Lagoon Road. (A May 1992 photograph depicts the metal plate affixed to one concrete waste pit/auger hole. See Fig. E.13.) The location and status of these auger holes should be determined.

Some soil contamination was found inside the TVA Fort Loudon/K-27 Transmission Line Right-of-Way. Consideration should be given to conducting a radiological scoping survey of the right-of-way because this area is cleared of vegetation by TVA approximately every three years. 4

There is also a need for a systematic surface beta-radiation scan of the entire Melton Valley area because of the recent "legacy" contamination findings of insoluble ${ }^{90} \mathrm{Sr}$-titanate particles throughout Melton Valley (McKenzie et al 1995). The areal extent of contamination throughout Melton Valley (and possibly the entire Oak Ridge Reservation) should be ascertained. The potential human exposures from ${ }^{90} \mathrm{Sr}$-titanate cannot be assessed until the full extent of the contamination has been determined. Existing aerial radiological surveys of

\footnotetext{
${ }^{4}$ Cleston Jones, Tennessee Valley Authority, personal communication to J. $\mathrm{K}$ Williams, Health Sciences Research Division, ORNL, May 1995.
} 
above-background gamma radiation on the Oak Ridge Reservation were not capable of finding surface beta-radiation contamination from ${ }^{90} \mathrm{Sr}$-titanate.

\subsection{COMPREHENSTVE RISK ASSESSMENT}

Currently, ORNL employees and the public are potentially exposed to ${ }^{90} \mathrm{Sr}$ - and ${ }^{137} \mathrm{Cs}$ contaminated biota adjacent to and possibly dispersed on public roads. There is also potential for vehicle contamination from debris from ${ }^{90} \mathrm{Sr}$-contaminated trees near Building $7819,{ }^{90} \mathrm{Sr}$ and ${ }^{137} \mathrm{Cs}$ in surface runoff from storm events over Lagoon Road, contamination adjacent to the north side of Lagoon Road (currently roped off), and "hot" particles found adjacent to Lagoon Road (see Fig. E.14). Human health risk assessments for these exposure pathways should be made before final cleanup options or future land use determinations (e.g., DOE's "Common Ground" process) are made for these contaminated areas.

\subsection{INTERIM CORRECTIVE MEASURES}

The problem of contaminated trees and other aboveground forest biomass is a delicate issue in corrective or remedial action planning. A balance must be struck between the extent of actions needed to protect human health and the environment and disturbance to the forest ecosystem from the action. For example, widespread deforestation in the White Oak Creek watershed could result in adverse ecological consequences. One anticipated result of deforestation is a net increase in surface and subsurface runoff, which potentially enhances radionuclide migration away from contaminated areas. A second anticipated result is an increase in cation leaching from the watershed, increasing ${ }^{90} \mathrm{Sr}$ leaching from the White Oak Creek drainage to the Clinch River. ${ }^{5}$ However, it is reasonable to recommend interim measures until a final assessment of the problem is made. Interim corrective measures might include the following:

- isolation of the contaminated area via roping or other barriers;

- measures to minimize the dispersion and redistribution of fugitive radionuclides;

- removal, treatment, or disposal of certain contaminated material; or

- closure of Lagoon Road.

Each of these options is briefly discussed below.

\subsection{Isolation of Contaminated Soil/Vegetation Areas}

Some radiation control measures already have been carried out by ORNL's Office of Radiation Protection at the contaminated-tree area north of Melton Valley Drive. A "Contamination Area" was established by encompassing the area with a plastic-link chain attached to metal posts. Warning signs were posted on the chain boundary. The measured

\footnotetext{
${ }^{5} \mathrm{C} . \mathrm{T}$. Garten, Jr., Environmental Sciences Division, ORNL, personal communication to J. $\mathrm{K}$. Williams, Health Sciences Research Division, ORNL, March 1993.
} 
level of surface contamination in the area and personnel protection requirements are specified on the signs. Additional measures might include the following:

- A weatherproof diagram of the contaminated tree areas depicting radiation levels should be maintained, updated, and made readily available to authorized personnel requiring site access. Instructions to contact responsible area personnel (e.g., ORNL's Office of Radiation Protection or ER Program personnel) with current telephone numbers should be included.

- The contaminated-tree area should be encircled by a roped or fenced boundary with "Contaminated Foliage" signs attached. This type of sign should specify the radiation hazard and date of such designation.

- Contaminated trees along Melton Valley Drive and Lagoon Road should be identified (e.g., painted with yellow or magenta paint). This may be performed using a predetermined configuration or marking on the tree.

- Radiation protection and monitoring measures (e.g., personal radiation monitoring devices) should be considered for personnel not affiliated with Lockheed Martin Energy Systems, Inc., who are involved with activities throughout Melton Valley. All activities that disturb or disperse soil or vegetation in Melton Valley should cease if personnel involved with such operations do not wear some type of radiation monitoring devices and protection gear. The use of personal respirators should be considered to minimize the inhalation of radioactively contaminated soil and dust particles.

\subsubsection{Minimization of Dispersion and Redistribution of Fugitive Radionuclides}

Interim surface contaminant-stabilization measures have been implemented at "hot" spots located near Melton Valley Drive (i.e., near entrance to SWSA 5). Although surface beta-gamma radiation levels were reduced by covering the hot spots with clean, uncontaminated gravel, the added material will increase the volume of waste to be disposed of during eventual cleanup (see Figs. E-15 through E.18).

The dispersion of fugitive radionuclides by litter fall from contaminated trees poses a complex cleanup challenge. One option to minimize the dispersion of contaminated leaves is to chemically kill "problem" trees, leave them standing, and periodically monitor contamination in and around the tree area.

\subsubsection{Removal, Treatment, and Disposal of Contaminated SoilVegetation}

Soil hot spots should be cleaned up and disposed of in a designated radioactive waste disposal site. During this survey, numerous hot spots were found adjacent to State Highway 95. Excavation of contaminated soil was immediately conducted. (See Figs. E-19 through E-21.) Excavation and removal of the contaminated material must be carried out in full compliance with current guidelines. It is essential that personnel from ORNL's Office of Radiation Protection monitor activities associated with any disturbance of soil or vegetation in contamination areas identified from this survey, or in Melton Valley. To verify that all 
characterization, cleanup, and post-cleanup activities are adequate to demonstrate that the site is radiologically clean, relative to applicable criteria, we recommend a confirmatory/verification survey at these locations.

The identified contaminated trees could be removed and disposed of in a designated radioactive waste disposal site; however, extensive tree removal may facilitate ${ }^{90} \mathrm{Sr}$ leaching from the site. ${ }^{6}$ On April 15, 1988, a meeting involving key ORNL personnel from the Environmental Sciences Division, Operations Division, and Environmental Compliance and Health Protection Division, was held to discuss strategies for dealing with ${ }^{90} \mathrm{Sr}$-contaminated trees in the area around Trench 7. The meeting attendees concluded that at least for the present, it is preferable to continue to accumulate the radioactivity, primarily ${ }^{90} \mathrm{Sr}$, in the trees in spite of the recognized related problems. That option was further supported by the belief that tree removal would facilitate more rapid movement of radioactivity away from the site through the surface water pathway via White Oak Lake.

\subsubsection{Closure of Lagoon Road}

Finally, one option to immediately limit public exposure to radioactive contamination is to isolate Lagoon Road from State Highway 95 and limit access to Lagoon Road to government vehicles. While this option would be associated with some employee resistance and a need to re-examine traffic control measures at the intersection of State Highway 95 and Bethel Valley Road, the reduced potential for public exposures to contaminated media and possible litigation would be realized.

\footnotetext{
${ }^{6} \mathrm{C}$. T. Garten, Jr., Environmental Sciences Division, ORNL, personal communication to J. $\mathrm{K}$ Williams, Health Sciences Research Division, ORNL, March 1993.
} 


\section{REFERENCES}

Coleman, R. L. 1993. Beta Dose Rate Evaluations with a Geiger-Mueller Pancake Detector, M.S. Thesis, Univ. of Tenn.

Lomenick, T. F. and K. E. Cowser. 1961. Status Report on Evaluation of Solid Waste Disposal at ORNL: II, ORNL-3182, Union Carbide Corp., Oak Ridge Natl. Lab.

McKenzie, S. P., et al. 1995. Surface Radiological Investigations at the Proposed SWSA 7 Site, Oak Ridge National Laboratory, Oak Ridge, Tennessee, ORNL/TM-13039, Lockheed Martin Energy Systems, Inc., Oak Ridge Natl. Lab.

Myrick, T. E., et al. 1987. Procedures Manual for the ORNL Radiological Survey Activities (RASA) Program, ORNL/TM-8600, Martin Marietta Energy Systems, Inc., Oak Ridge Natl. Lab.

Ohnesorge, W. F., et al. 1981. An Environmental Radiological Survey of the IntermediateLevel Waste System Pipeline, ORNL/TM-7858, Union Carbide Corp., Oak Ridge Natl. Lab.

ORNL. 1991. Procedures and Practices for Radiation Protection and Radiation Monitoring, Health Physics Procedure RP-2.5, December 1, 1991, Martin Marietta Energy Systems, Inc., Oak Ridge Natl. Lab.

ORNL. 1995. Measurement Applications and Development Group Guidelines, ORNL-6782, Martin Marietta Energy Systems, Inc., Oak Ridge Natl. Lab.

Williams, J. K, et al. 1993. A Radiological and Chemical Investigation of the 7500 Area Contamination Site at Oak Ridge National Laboratory, Oak Ridge, Tennessee, ORNL/ER-143, Martin Marietta Energy Systems, Inc., Oak Ridge Natl. Lab. 
Appendix A

RESULTS OF THE SURFACE GAMMA SURVEY ALONG STATE HIGHWAY 95, LAGOON ROAD, AND MELTON VALLEY DRIVE 


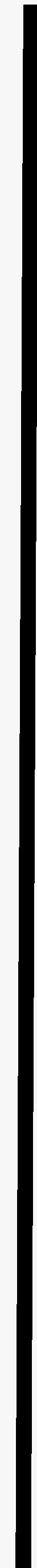




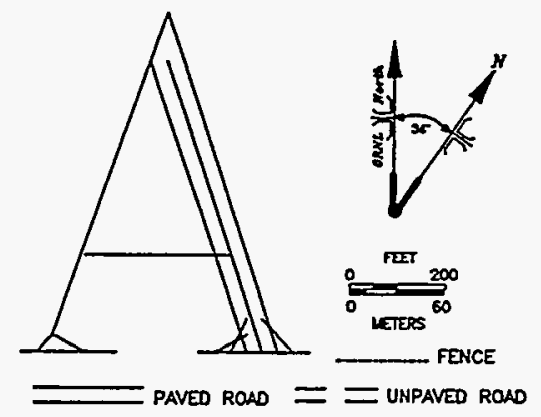

ORNL-DWG 95-6007

4-14 SURFACE GMMM EXPOSURE RATES (LR/h)

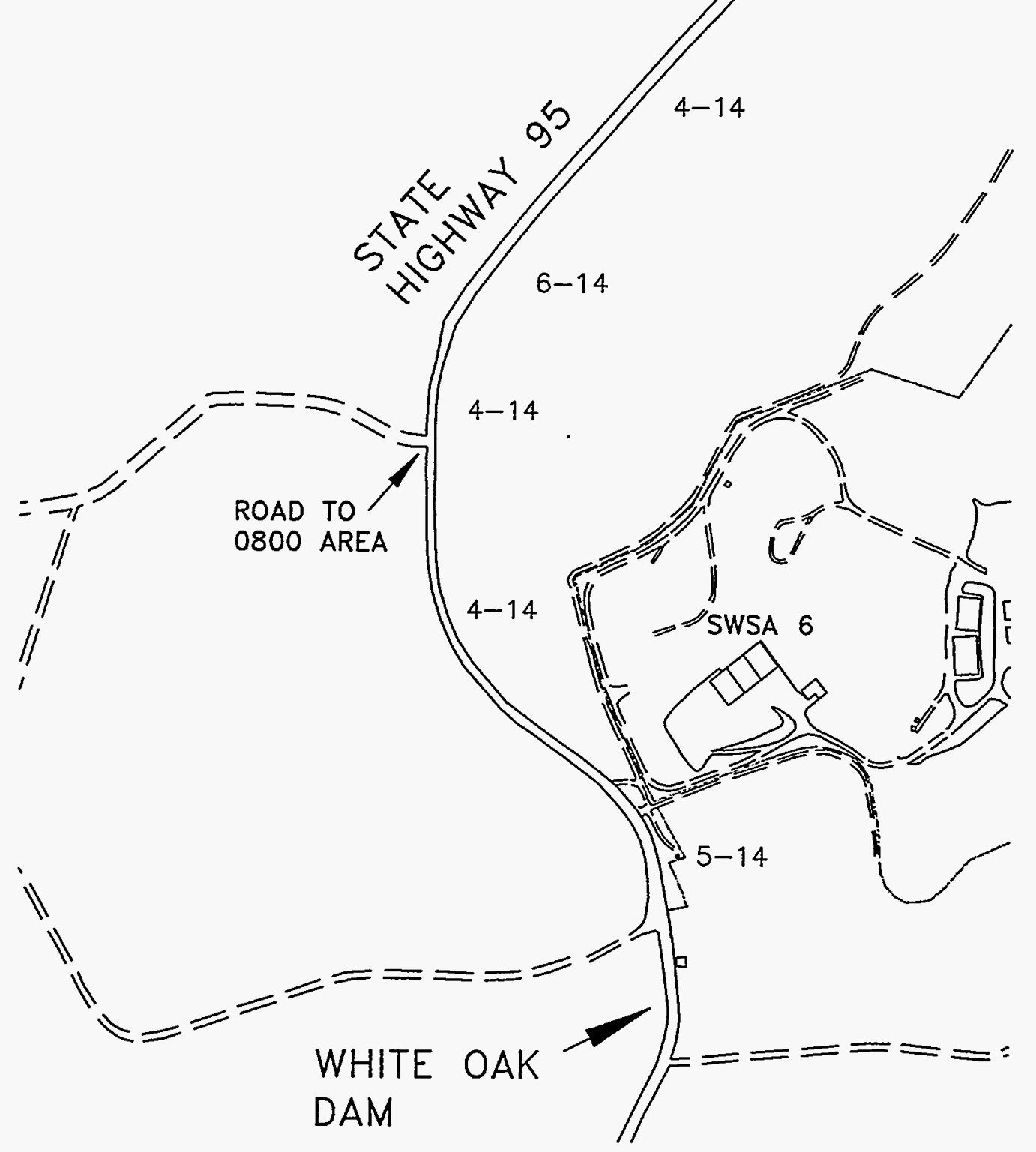

Fig. A.1. Diagram showing surface gamma exposure rates $(\mu R / h)$ along the east side of State Highway 95 south of the Lagoon Road intersection (Section A). 


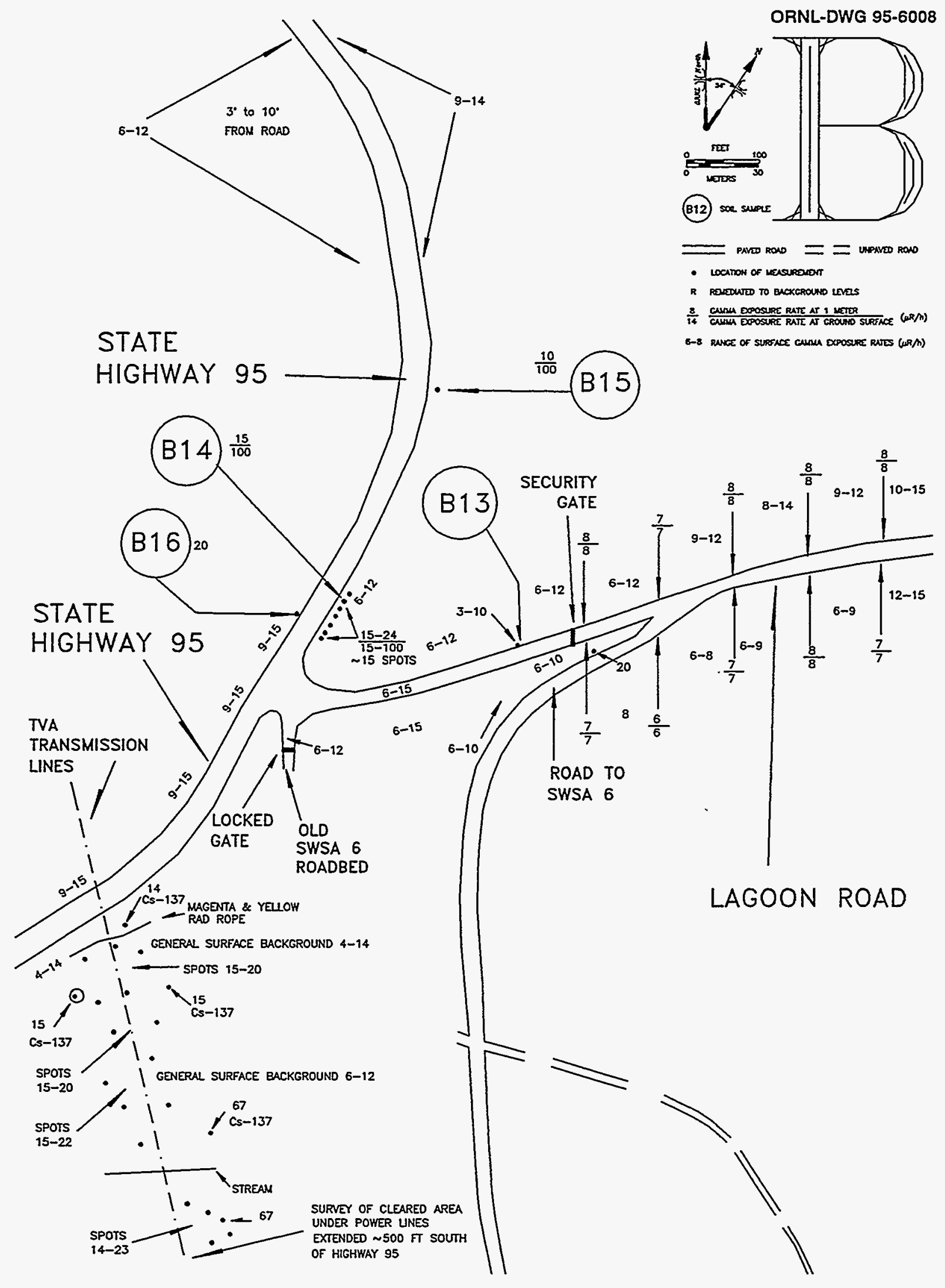

Fig. A.2. Diagram showing surface and selected 1-m gamma exposure rates $(\mu R / h)$ near the intersection of State Highway 95 and Lagoon Road (Section B). Surface gamma levels in the cleared area beneath the TVA transmission lines are shown in the lower left section of the diagram. 

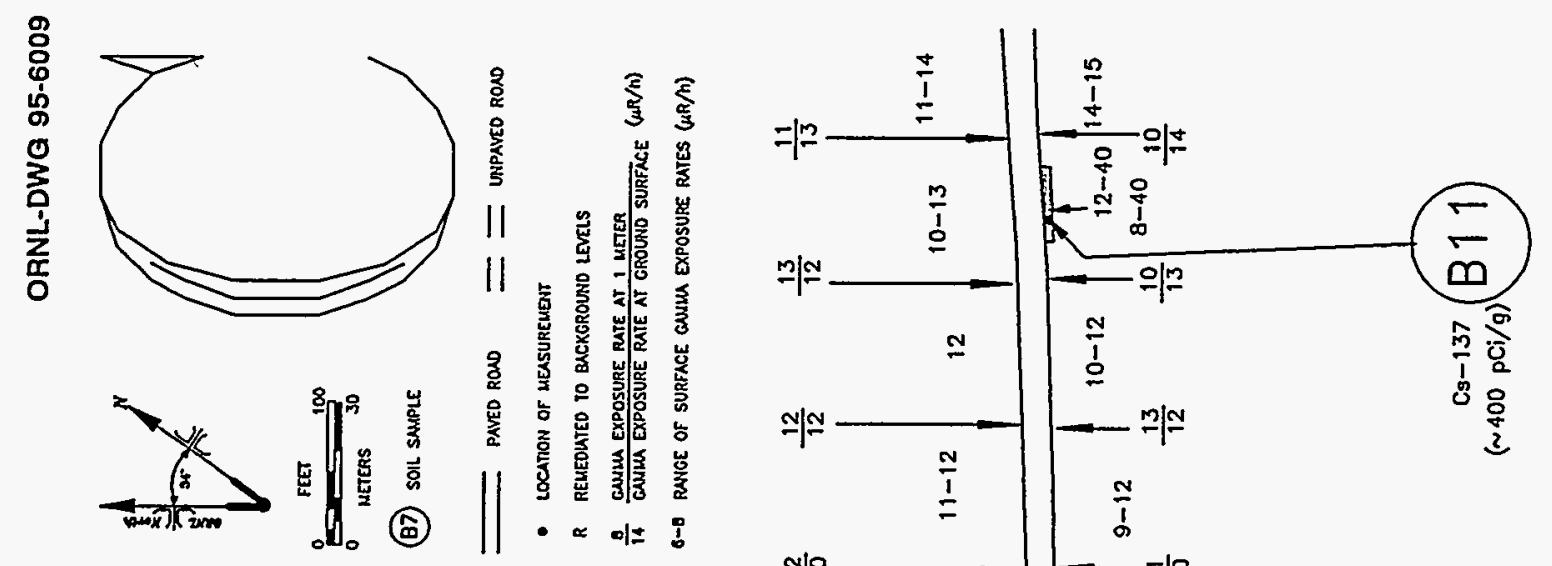

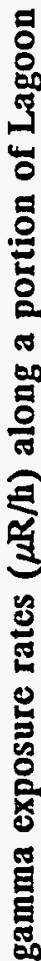

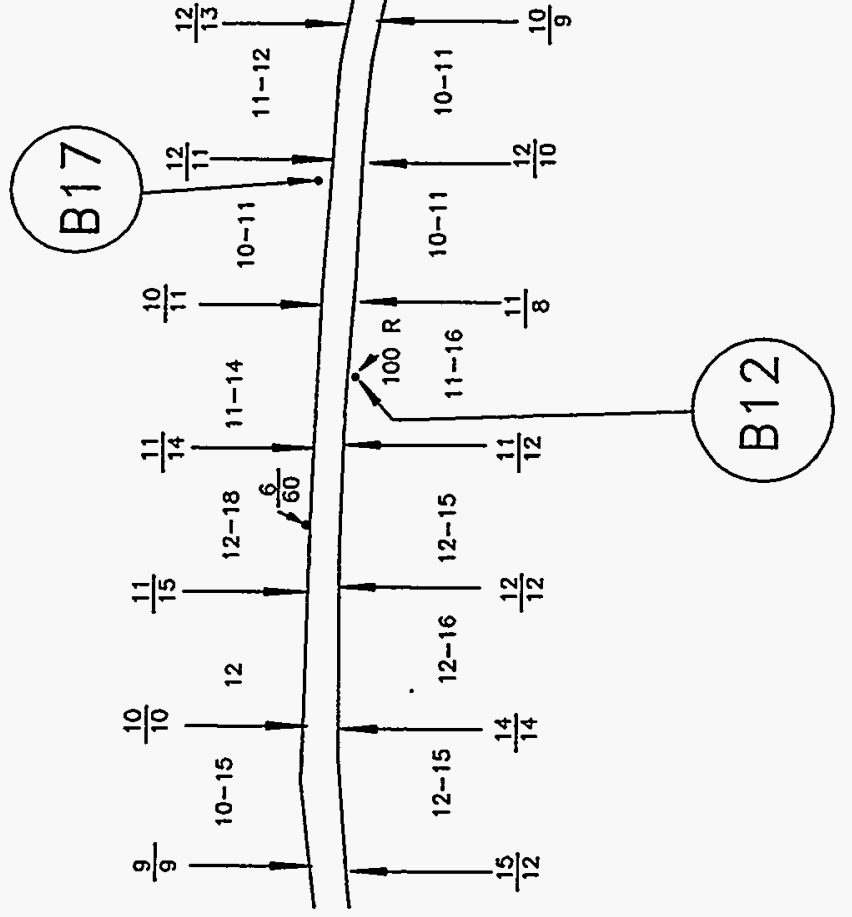

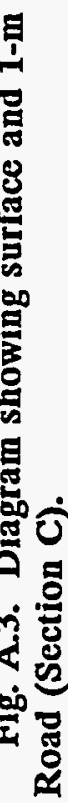




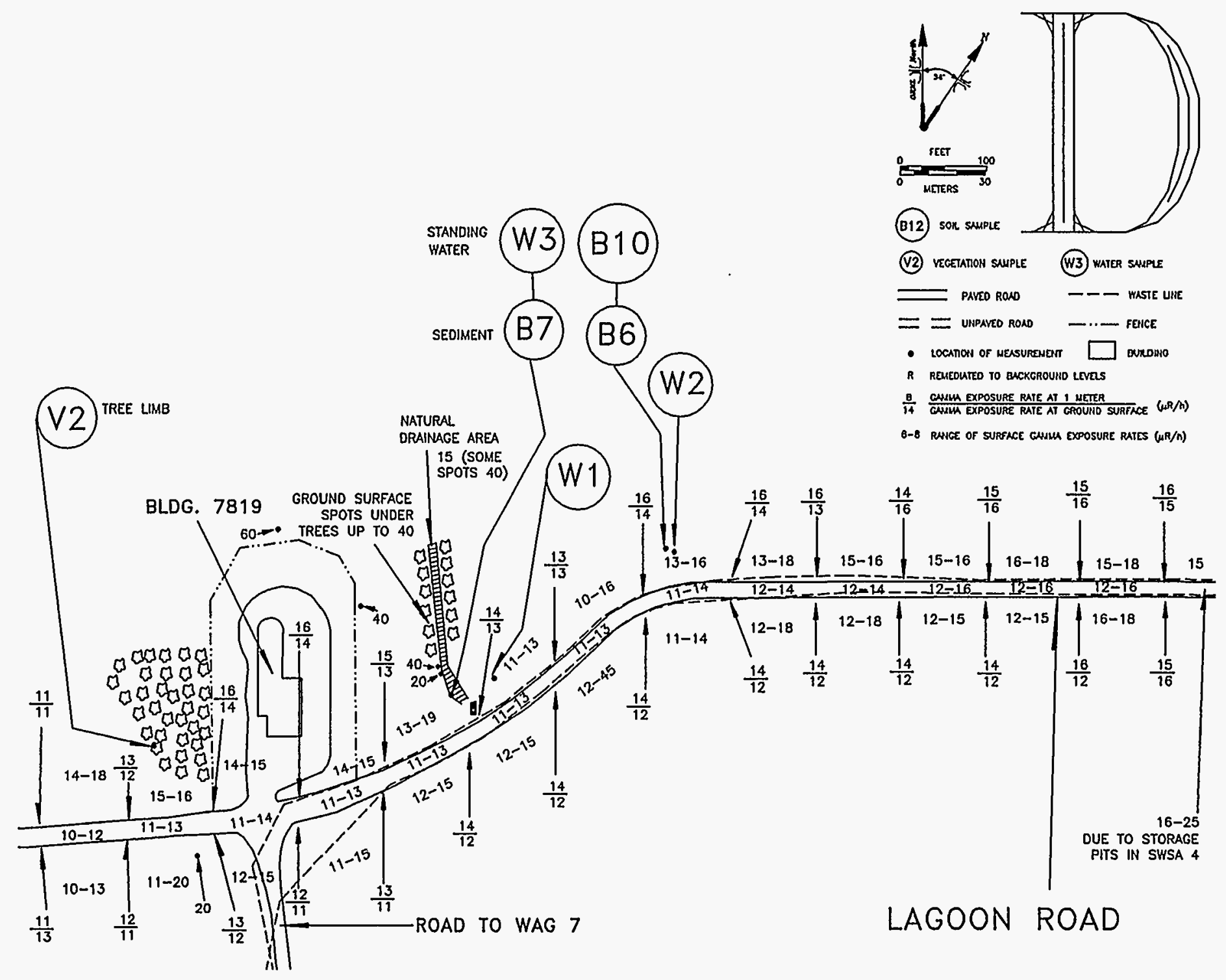

Fig. A.4. Diagram showing surface and 1-m gamma exposure rates $(\mu R / h)$ along Lagoon Road in the area near Building 7819 (Section D). 

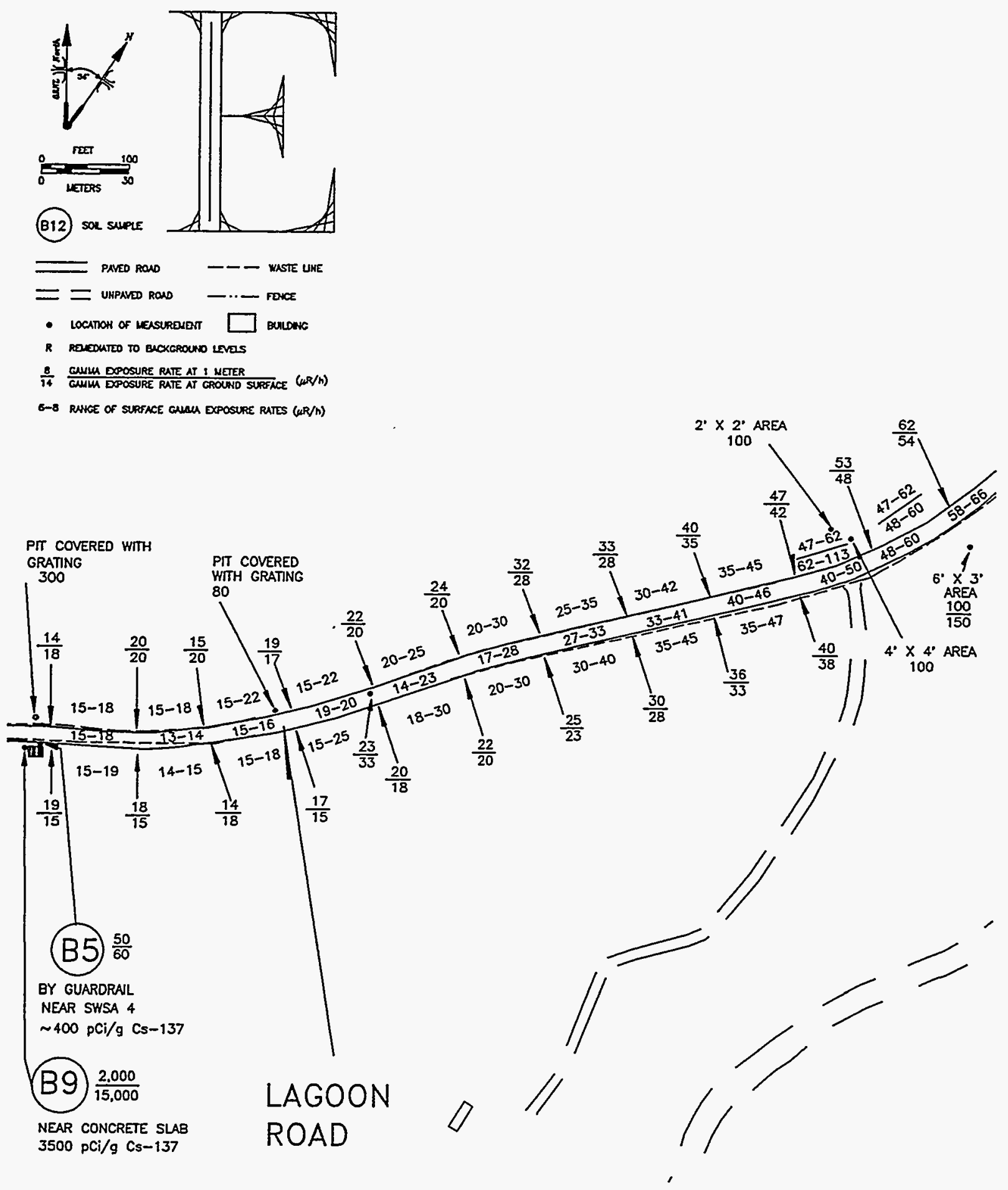

Fig. A.5. Diagram showing surface and 1-m gamma exposure rates $(\mu R / h)$ along a portion of Lagoon Road (Section E). 


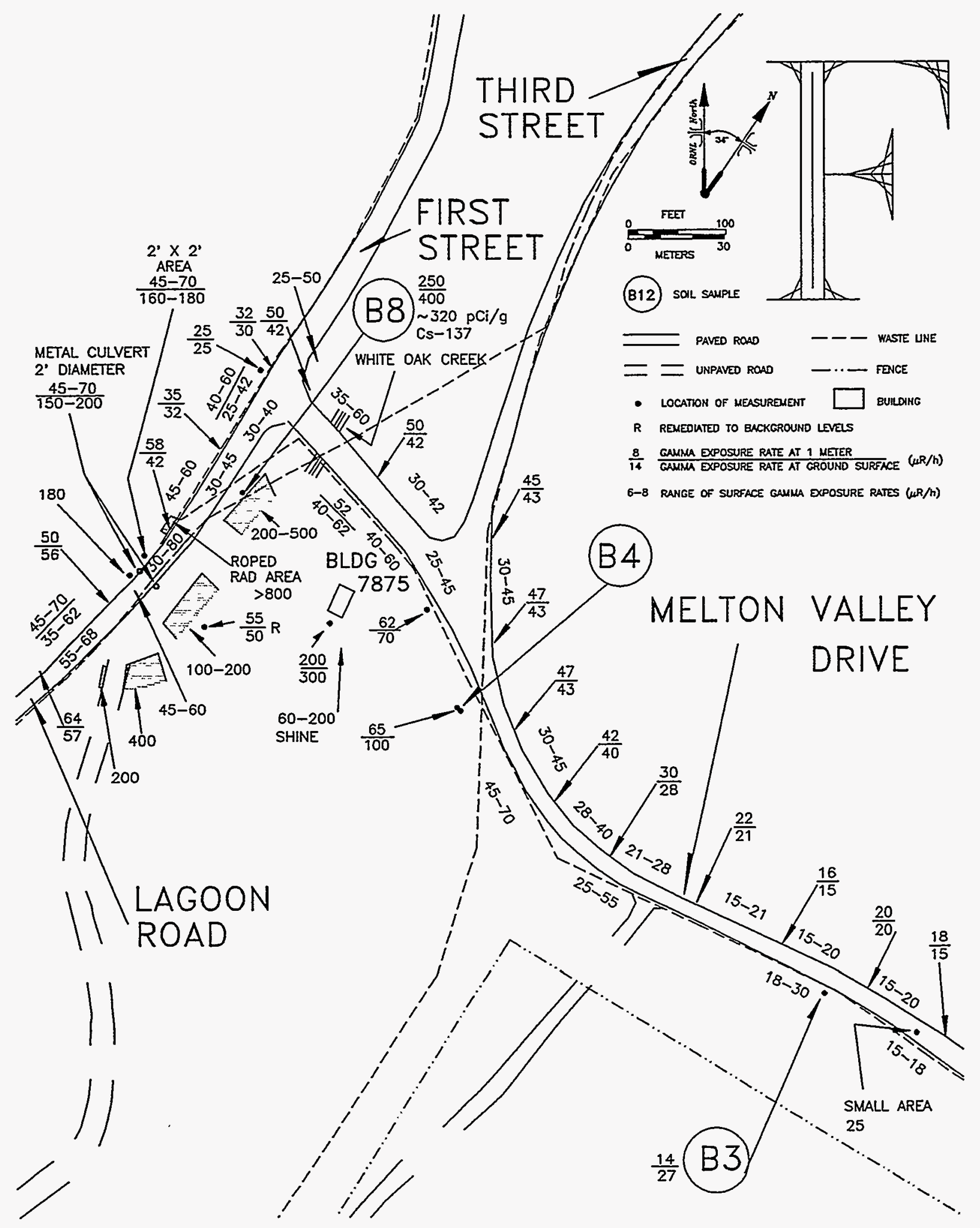

Fig. A.6. Diagram showing surface and 1-m gamma exposure rates $(\mu \mathrm{R} / \mathrm{h})$ near the intersection of Lagoon Road and Melton Valley Drive (Section F). 

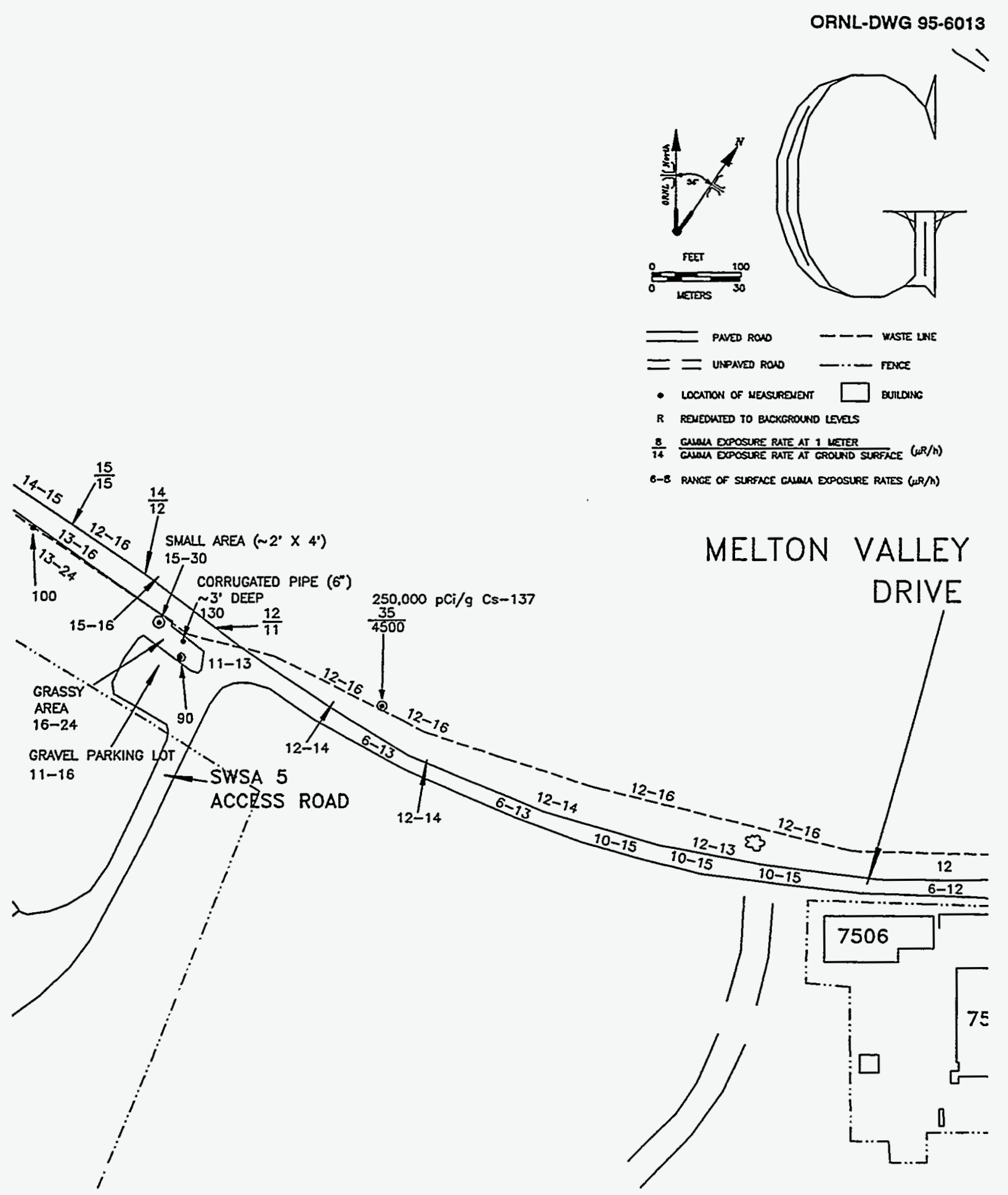

Fig. A.7. Diagram showing surface and selected $1-m$ gamma exposure rates $(\mu R / h)$ along a portion of Melton Valley Drive (Section G). 


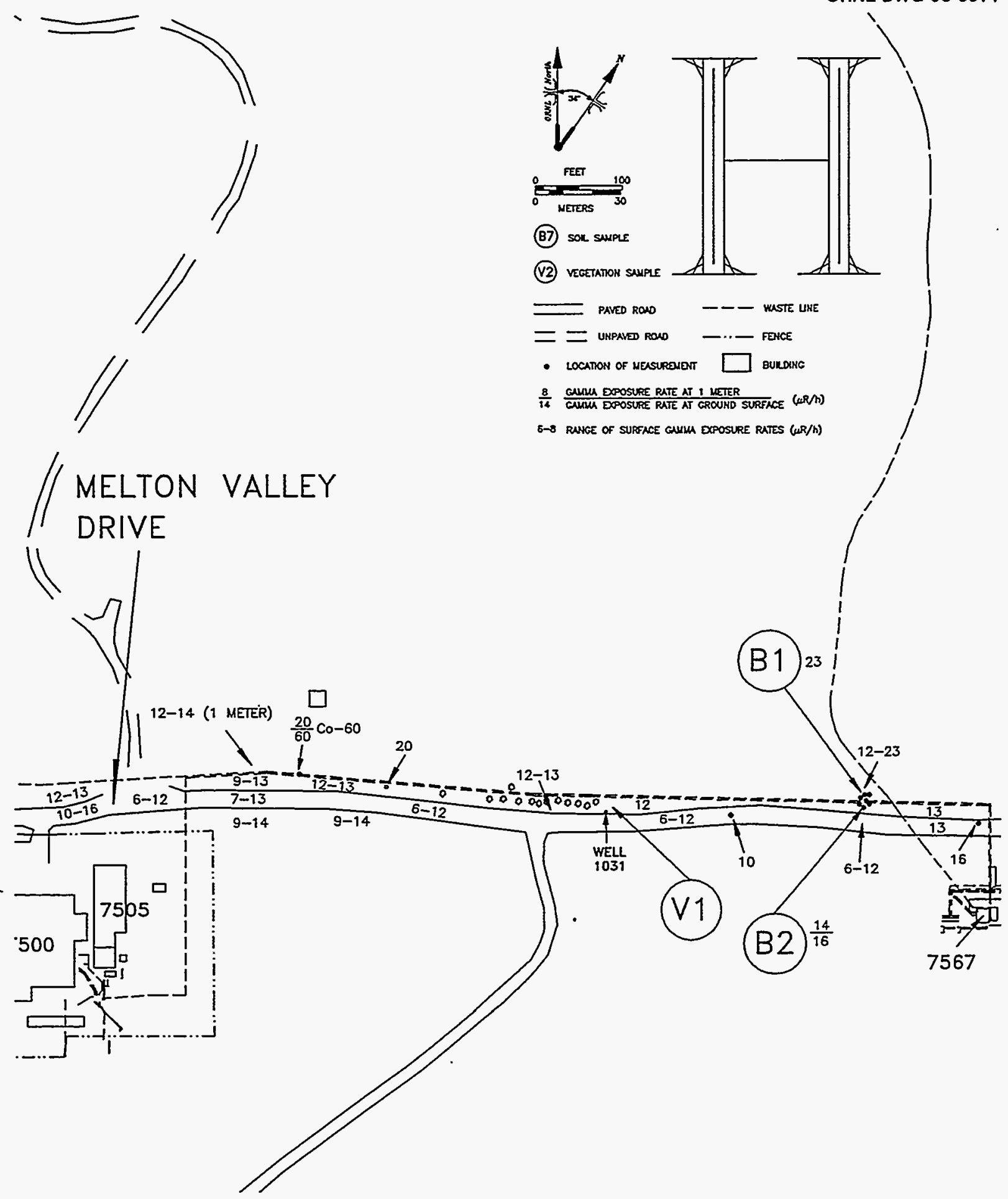

Fig. A.8. Diagram showing surface and selected 1-m gamma exposure rates $(\mu R / h)$ along a portion of Melton Valley Drive (Section H). 
Appendix B

RESULTS OF SURFACE BETA-GAMMA SPOT-CHECK MEASUREMENTS ALONG STATE HIGHWAY 95, LAGOON ROAD, AND MELTON VALLEY DRIVE 



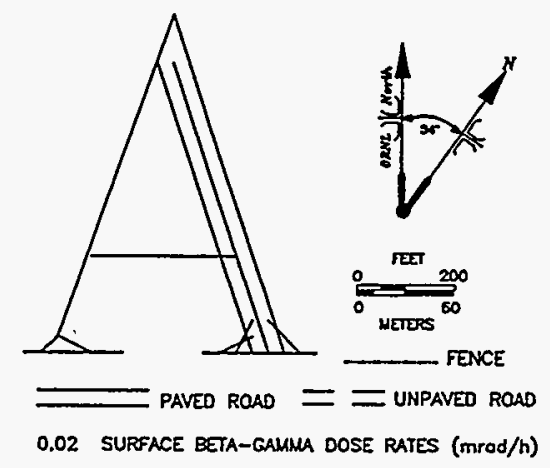

ORNL-DWG 95-6015

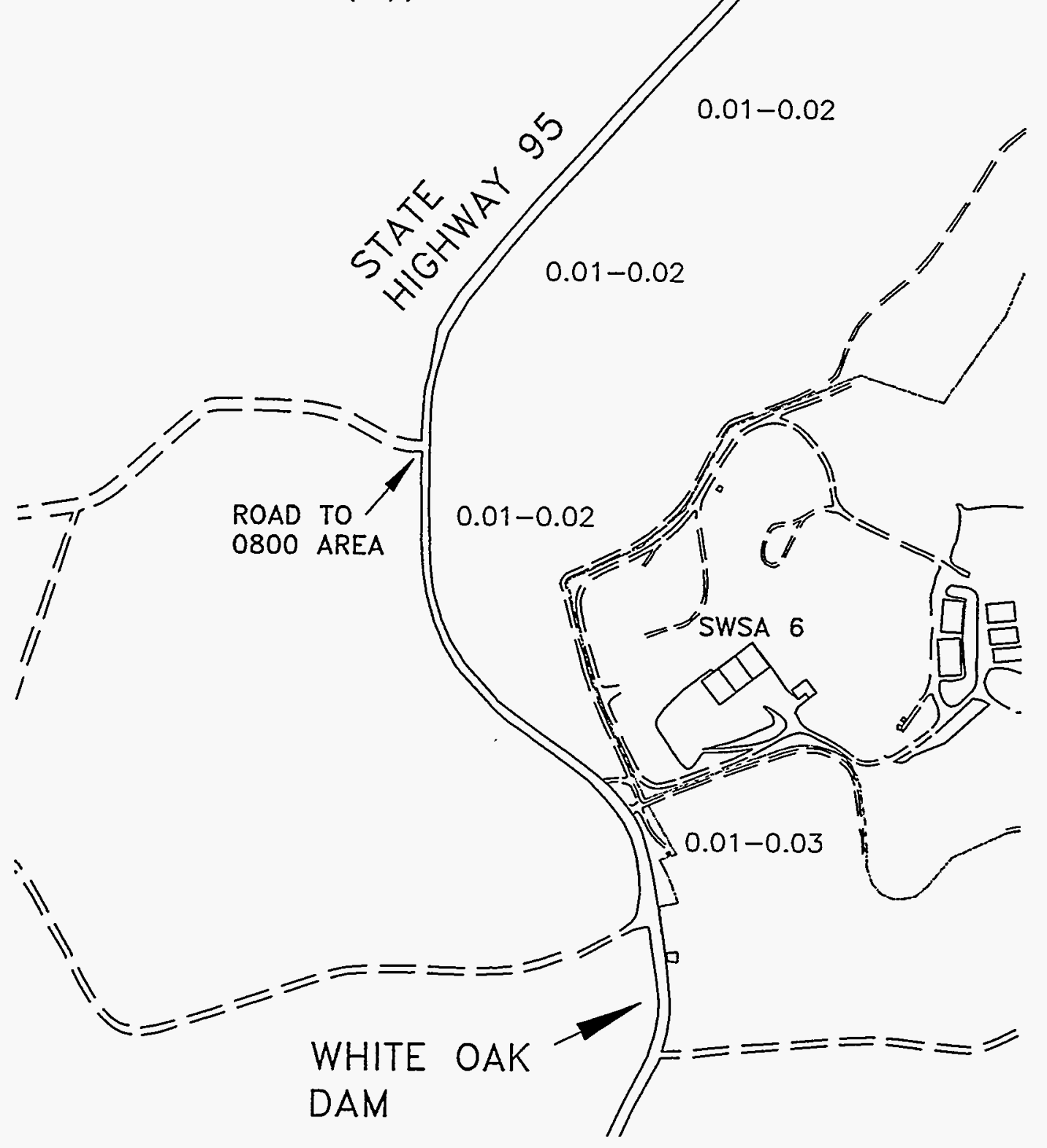

Fig. B.1. Diagram showing surface beta-gamma dose rates (mrad/h) along the east side of State Highway 95 south of the Lagoon Road intersection (Section A). 


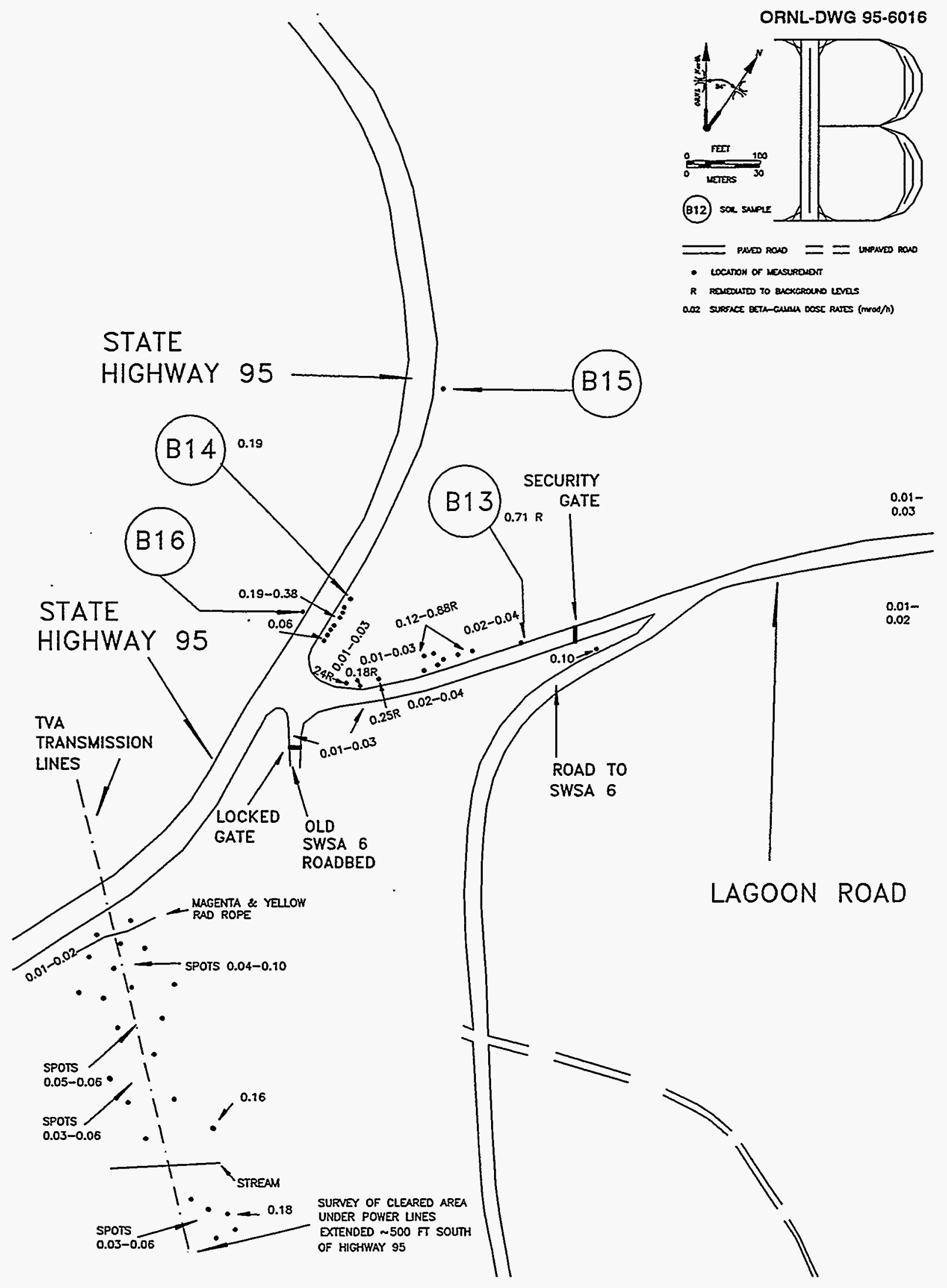

Fig. B.2. Diagram showing surface beta-gamma dose rates (mrad/h) near the intersection of State Highway 95 and Lagoon Road (Section B). Surface beta-gamma levels in the cleared area beneath the TVA transmission lines are shown in the lower left section of the diagram. 


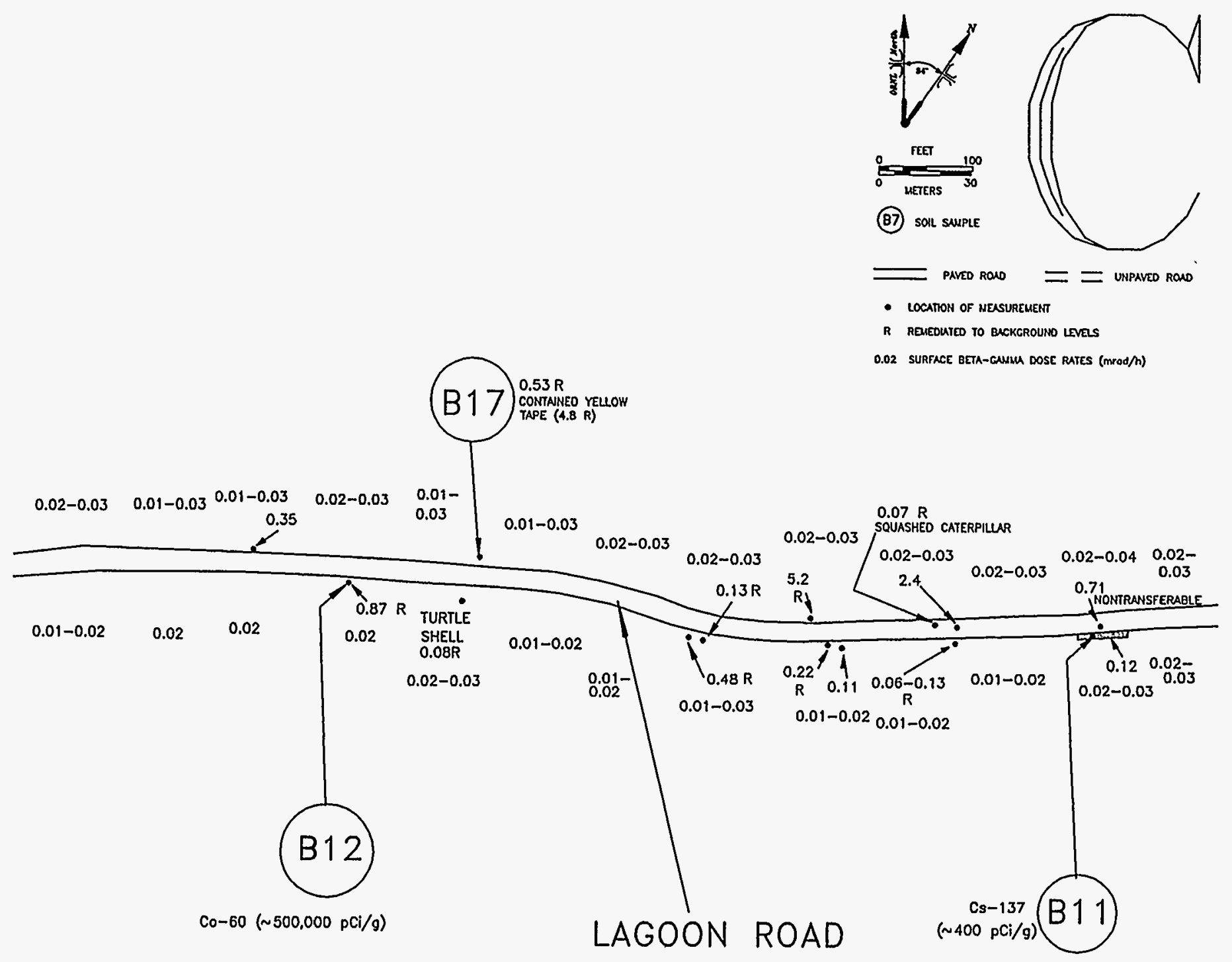

Fig. B.3. Diagram showing surface beta-gamma dose rates $(\mathrm{mrad} / \mathrm{h})$ along a portion of Lagoon Road (Section C). 


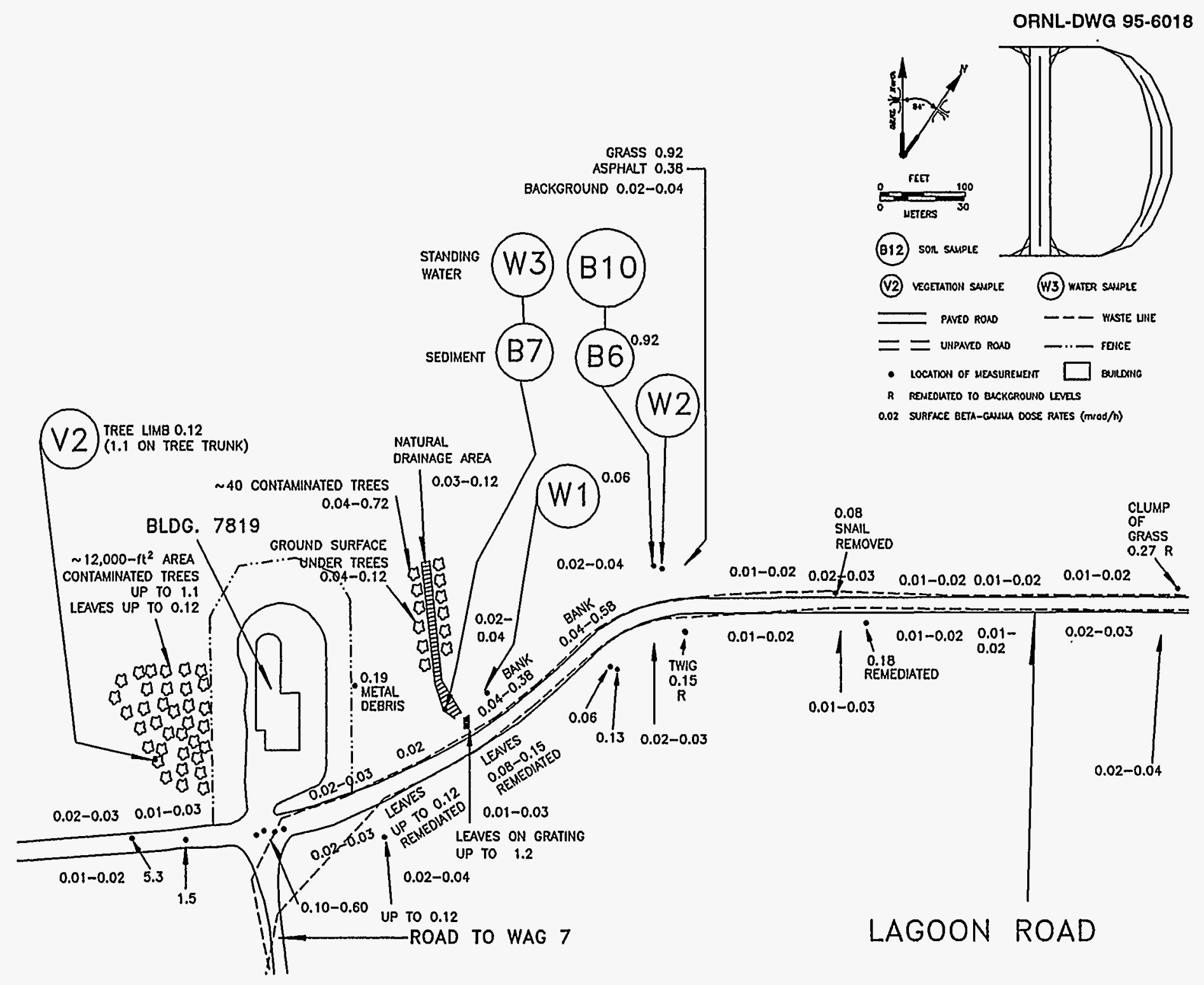

Fig. B.4. Diagram showing surface beta-gamma dose rates (mrad/h) along Lagoon Road in the area near Building 7819 (Section D). 


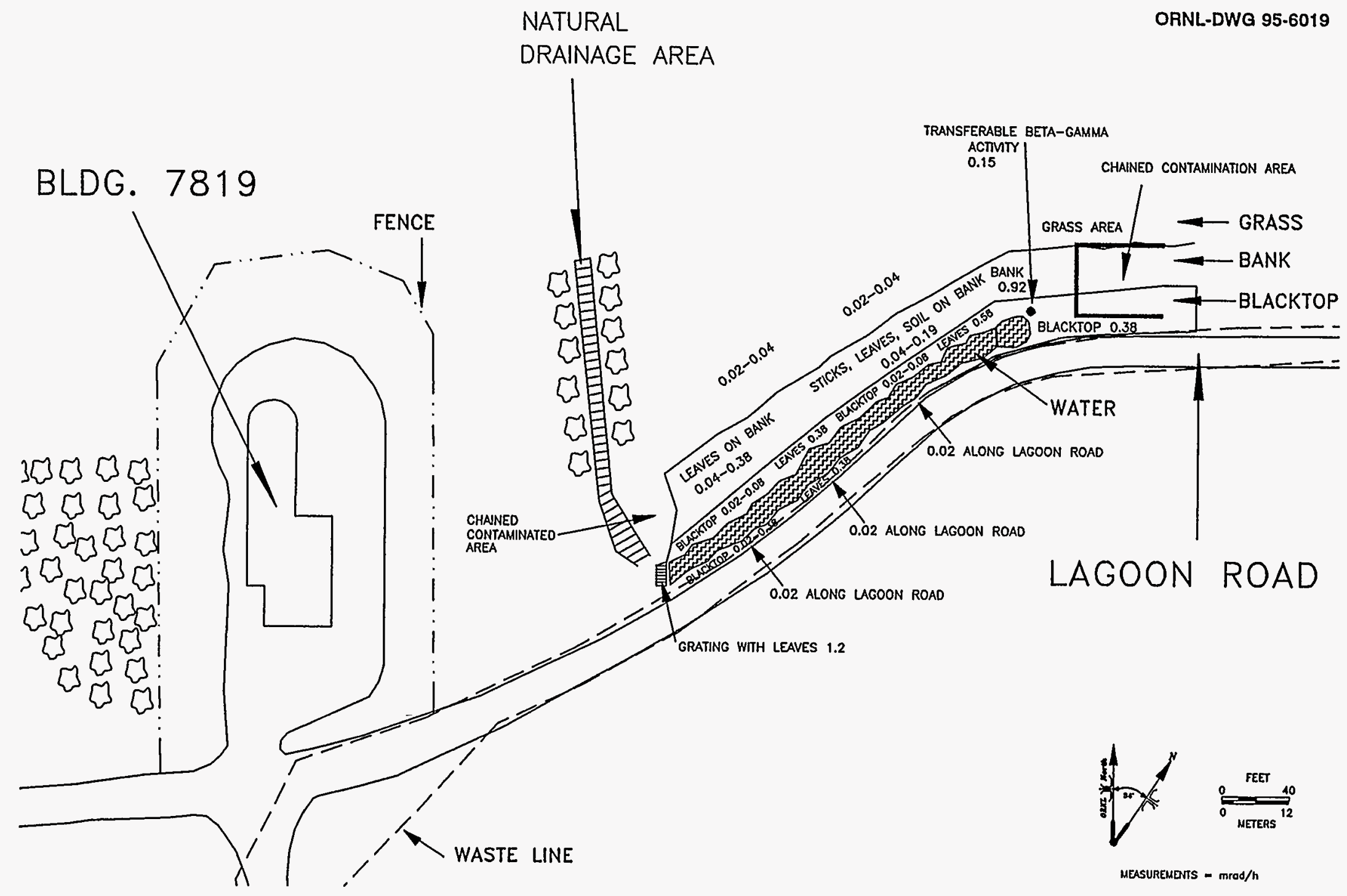

Fig. B.5. Diagram showing surface beta-gamma dose rates $(\mathrm{mrad} / \mathrm{h})$ on the bank cast of a natural drainage area near Building 7819. 

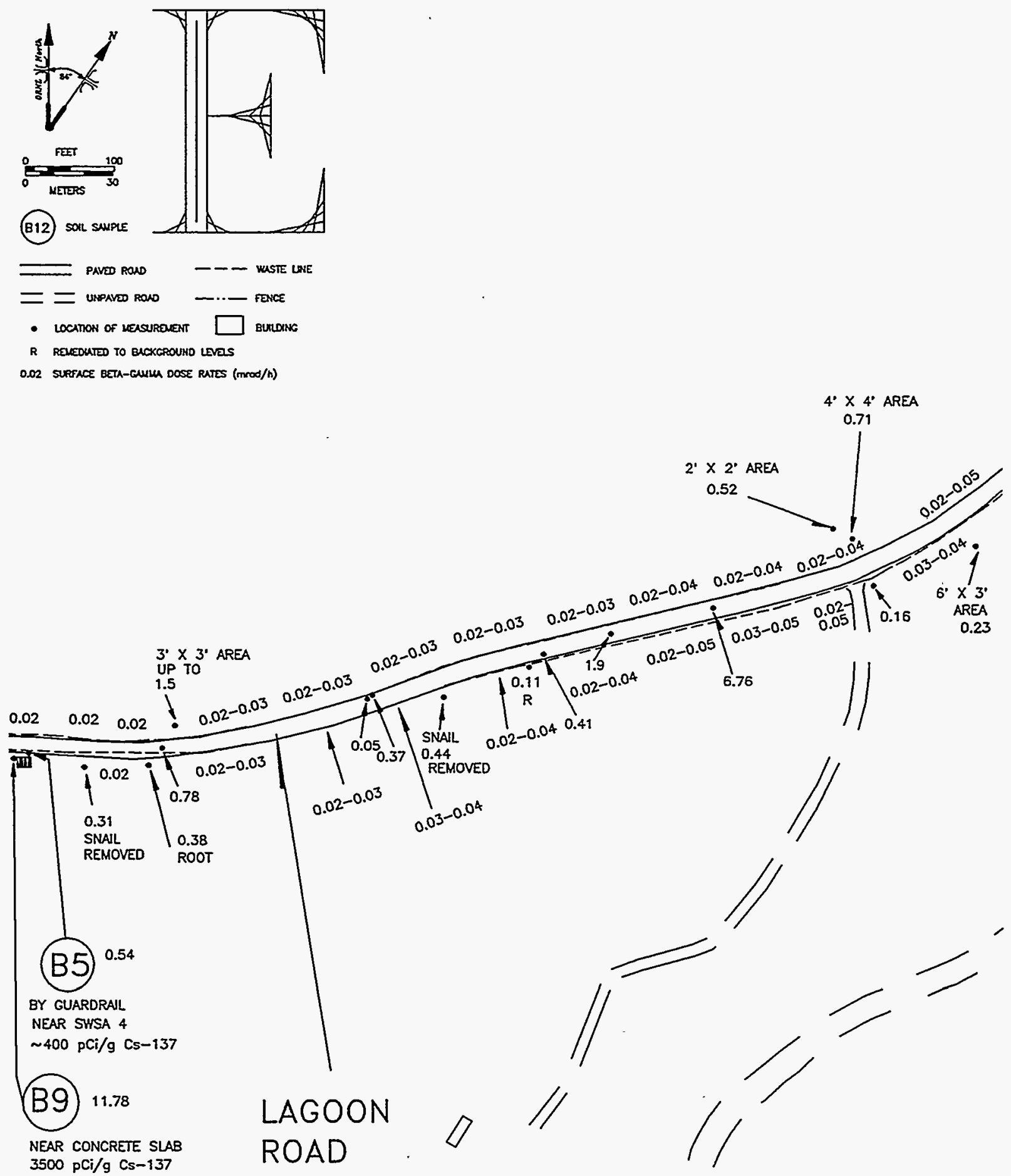

Fig. B.6. Diagram showing surface beta-gamma dose rates (mrad/h) along a portion of Lagoon Road (Section E). 


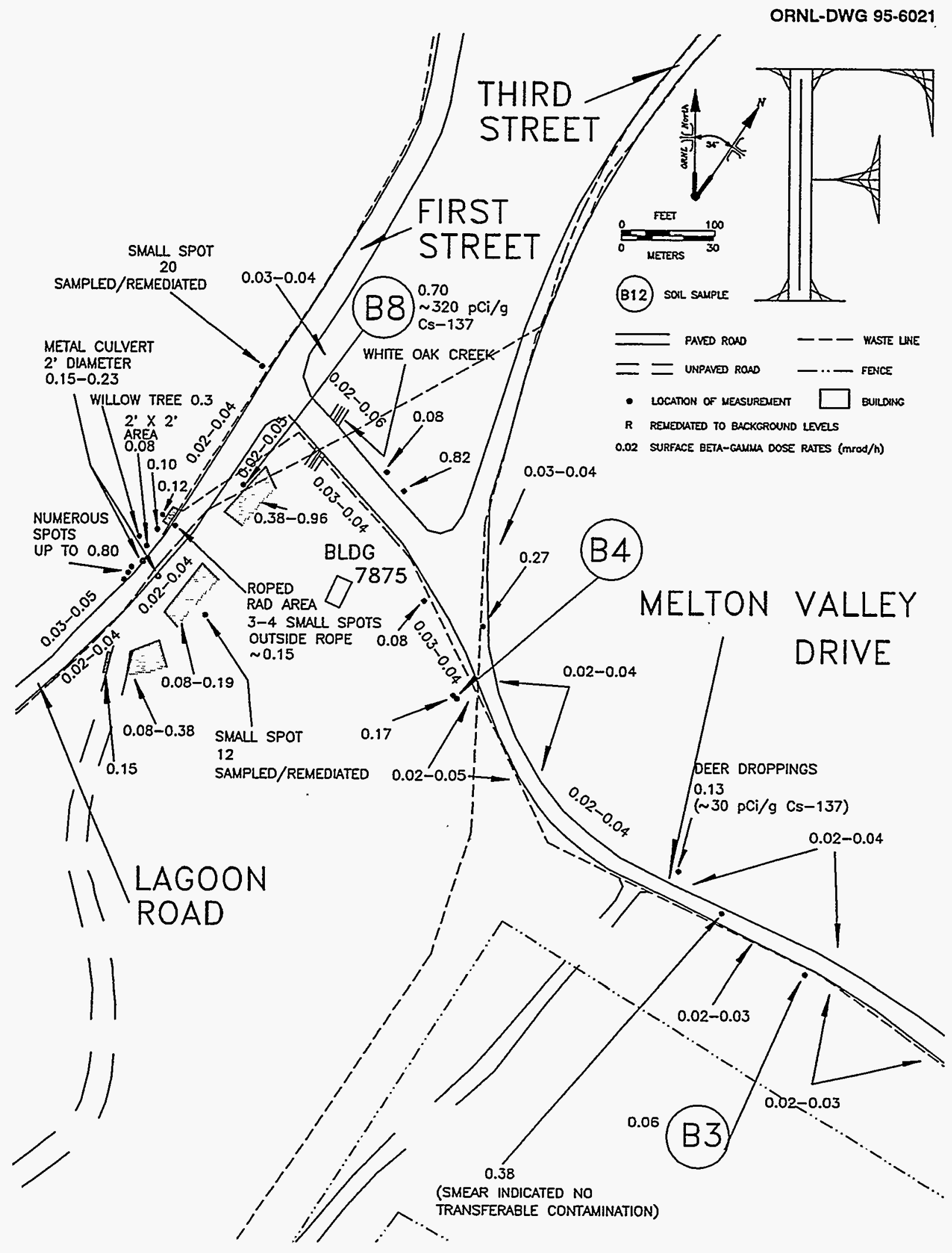

Fig. B.7. Diagram showing surface beta-gamma dose rates (mrad/h) near the intersection of Lagoon Road and Melton Valley Drive (Section F). 


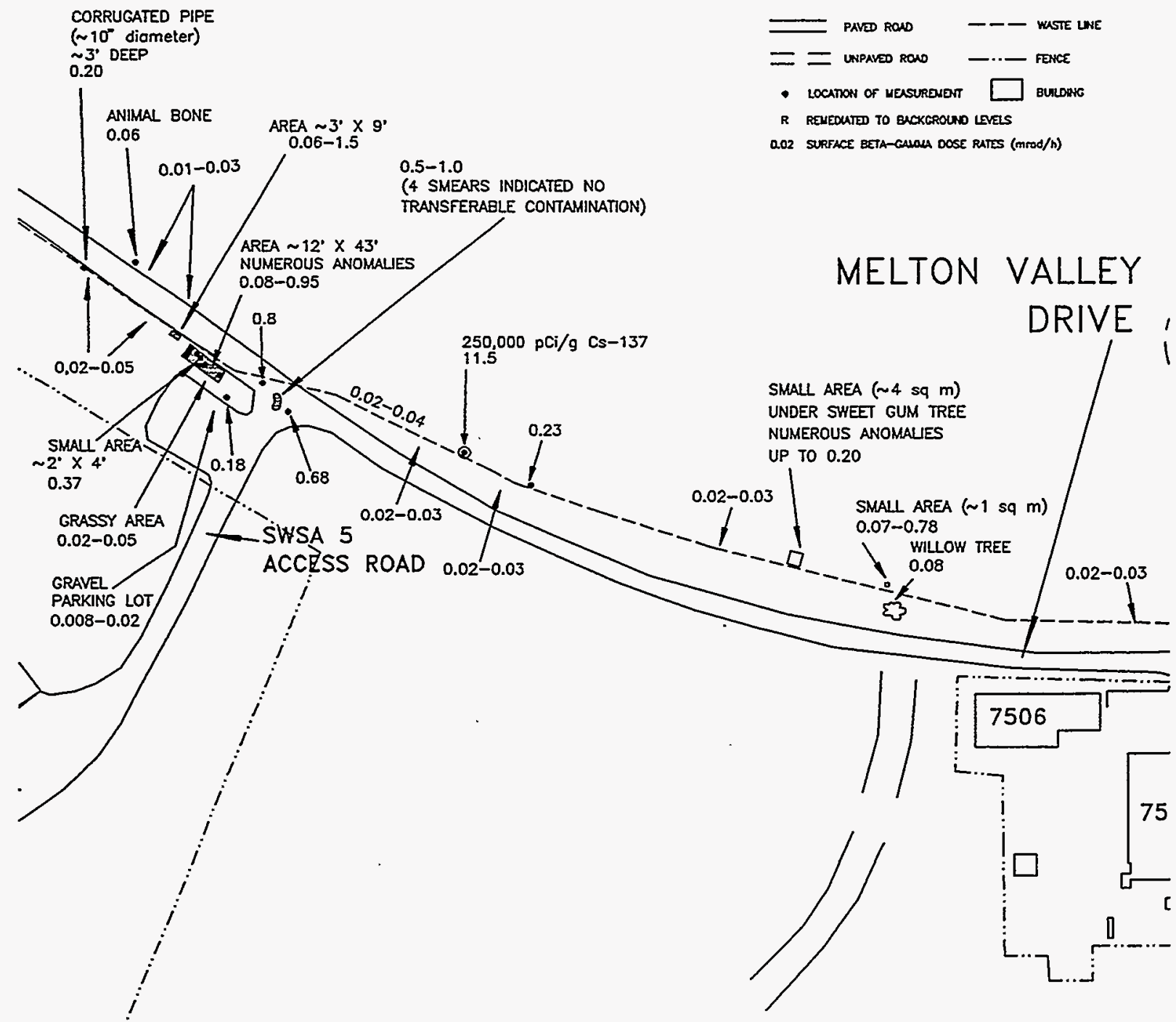

Fig. B.8. Diagram showing surface beta-gamma dose rates (mrad/h) along a portion of Melton Valley Drive (Section G). 


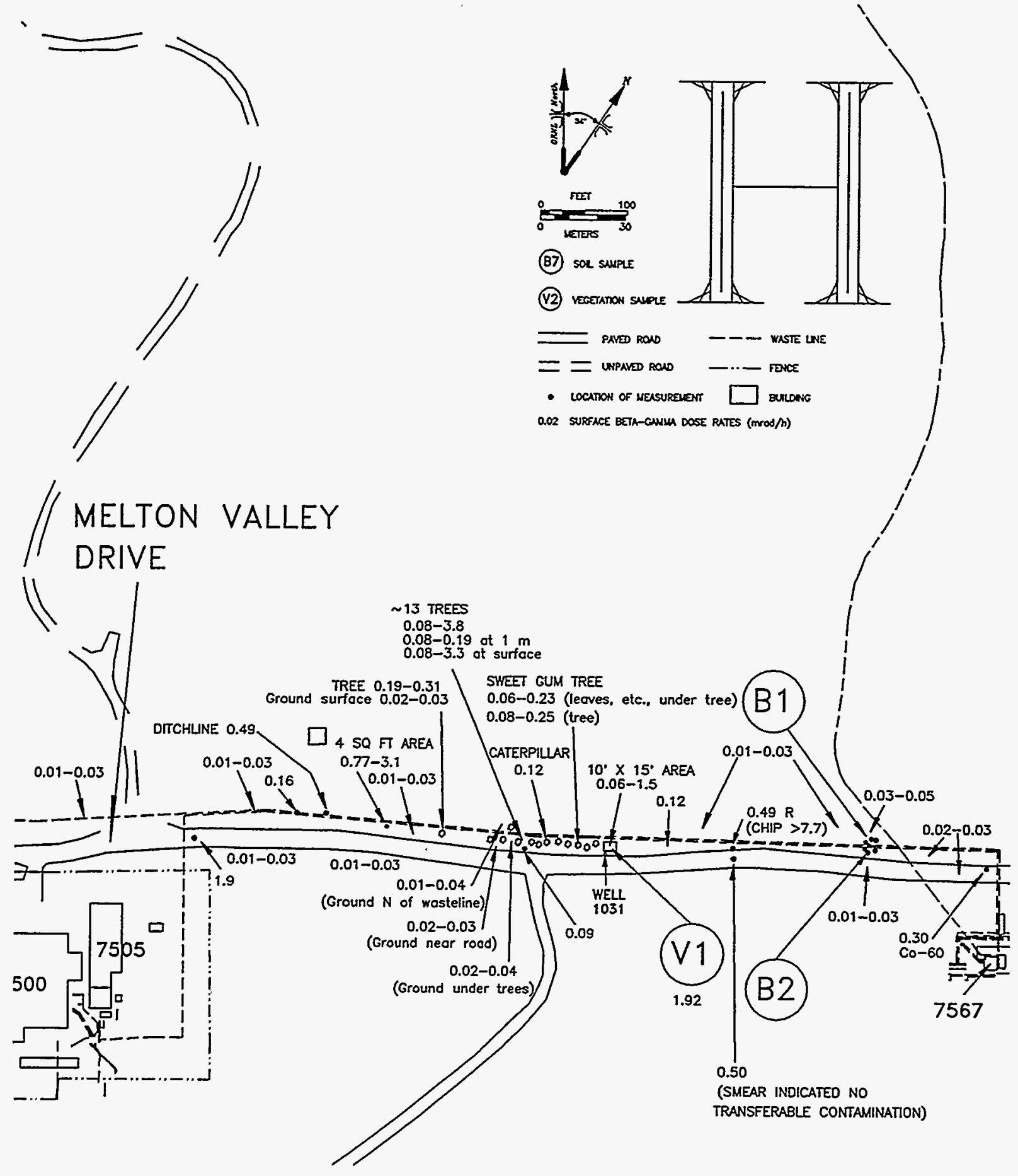

Fig. B.9. Diagram showing surface beta-gamma dose rates (mrad/h) along a portion of Melton Valley Drive (Section H). 


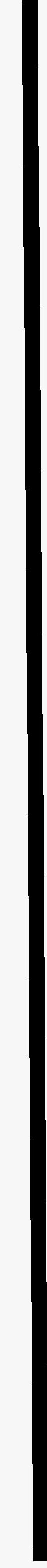


Appendix C

DETAIIS OF THE 100-FT GRID ESTABLISHED ALONG STATE HIGHWAY 95, LAGOON ROAD, AND MELTON VALLEY DRIVE 



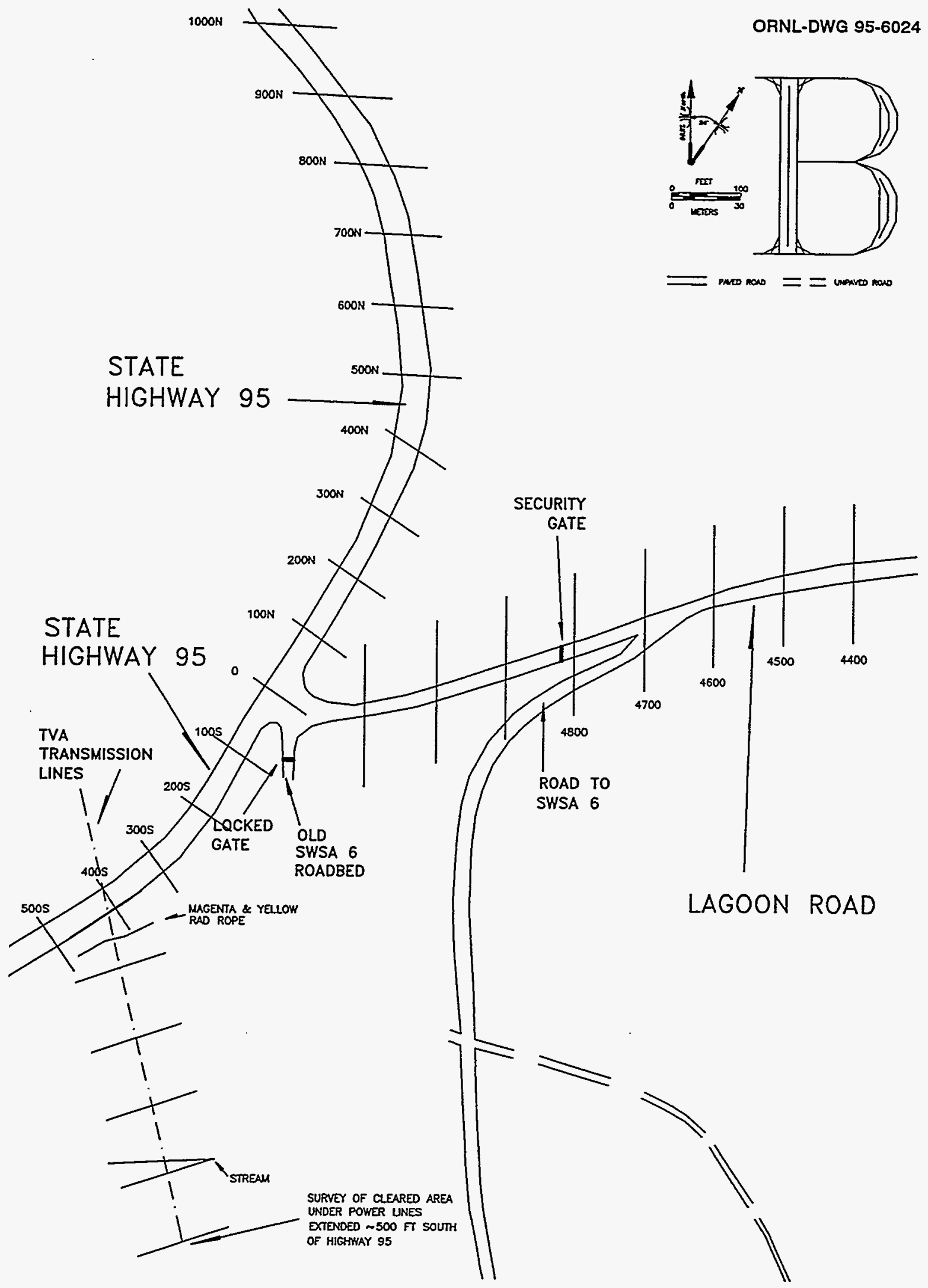

Fig. C.1. Diagram showing 100 -ft grid established near the intersection of State Highway 95 and Lagoon Road (Section B). 

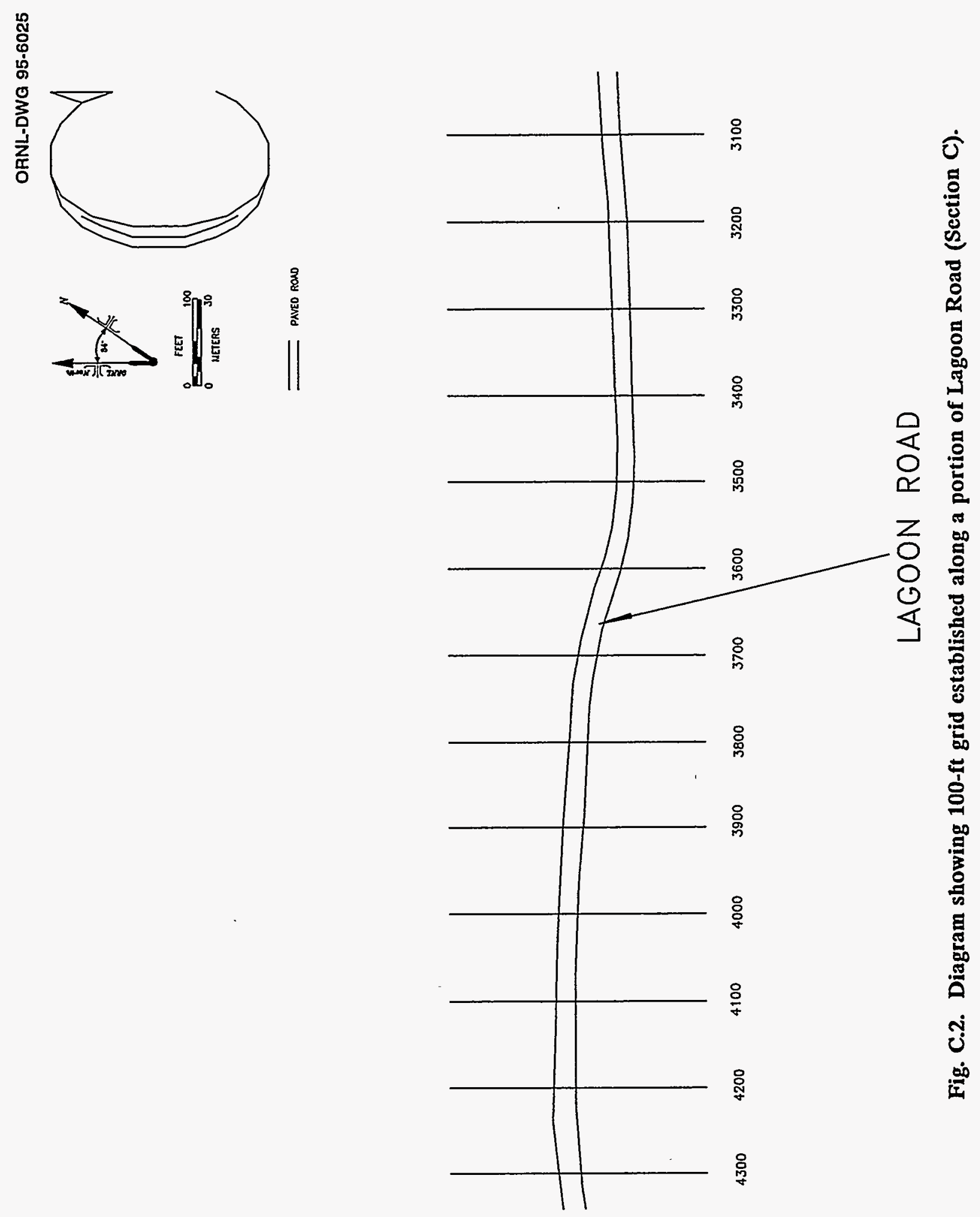
ORNL-DWG 95.6026

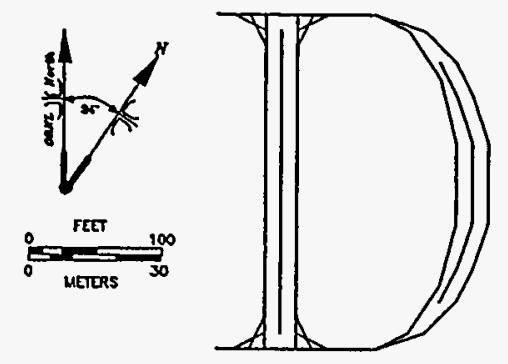

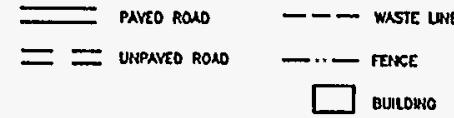

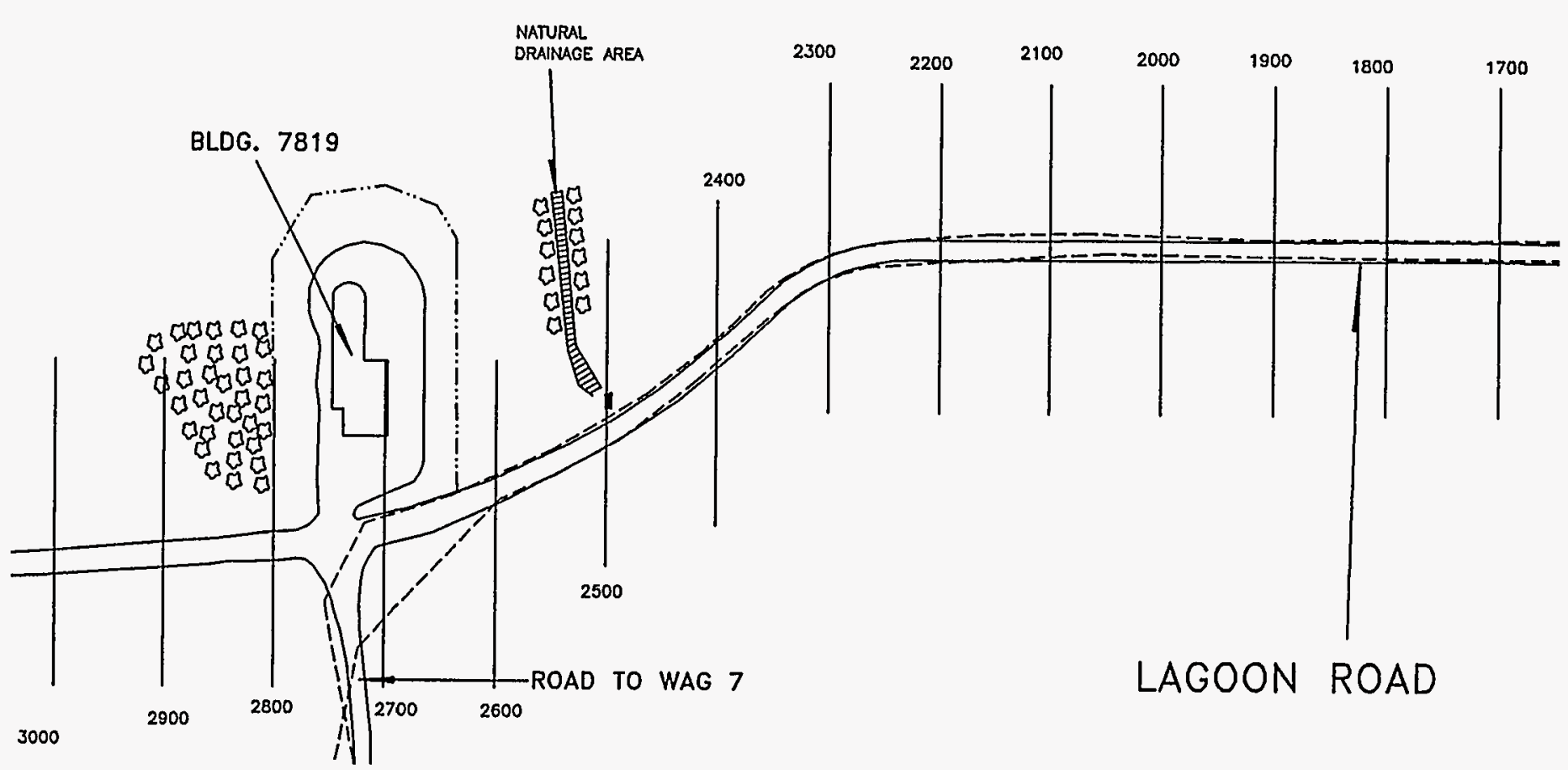

Fig. C.3. Diagram showing 100-ft grid established along Lagoon Road in the arca ncar Building 7819 (Section D). 
ORNL-DWG 95-6027
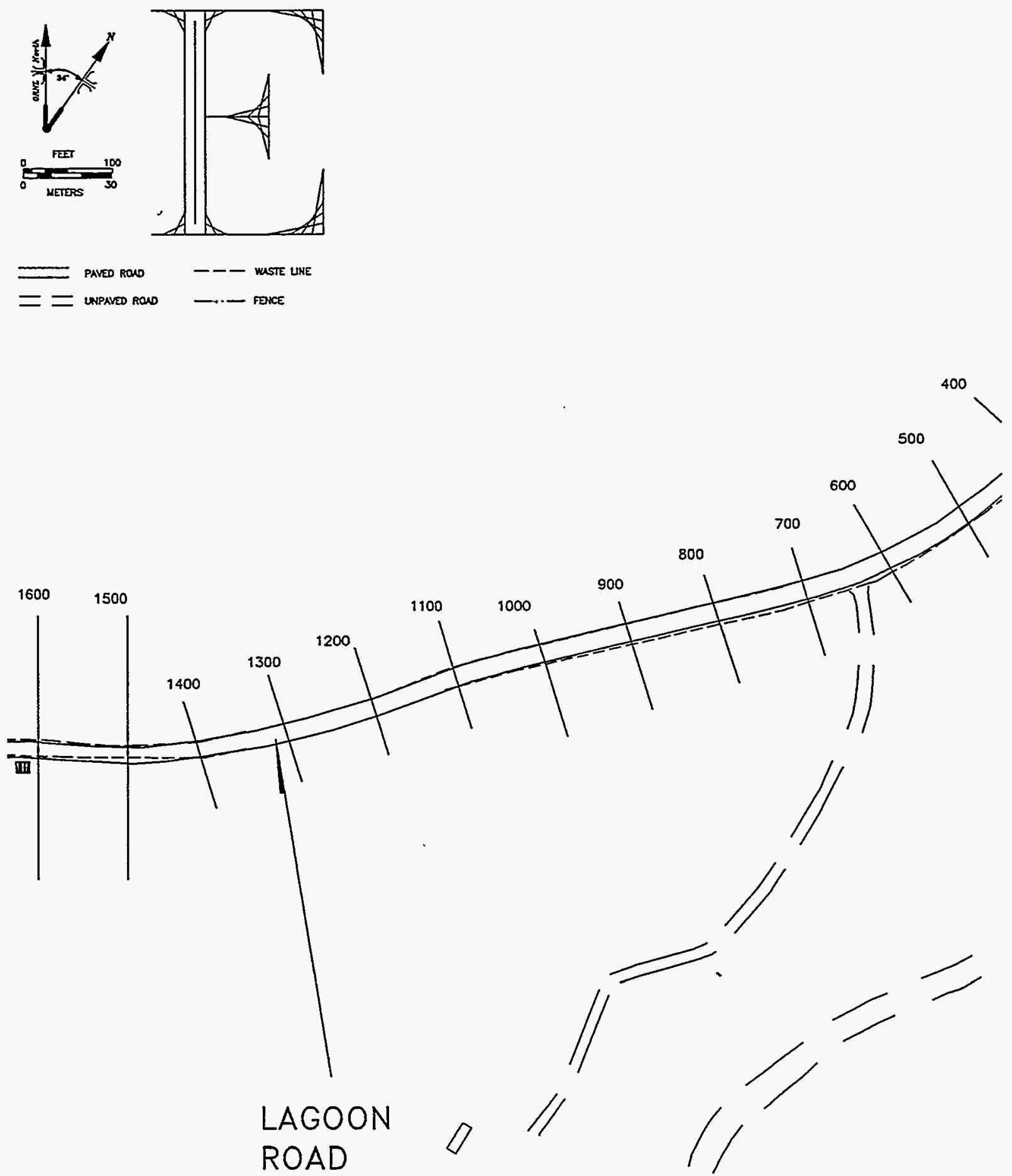

Fig. C.4. Diagram showing 100-ft grid established along a portion of Lagoon Road (Section E). 


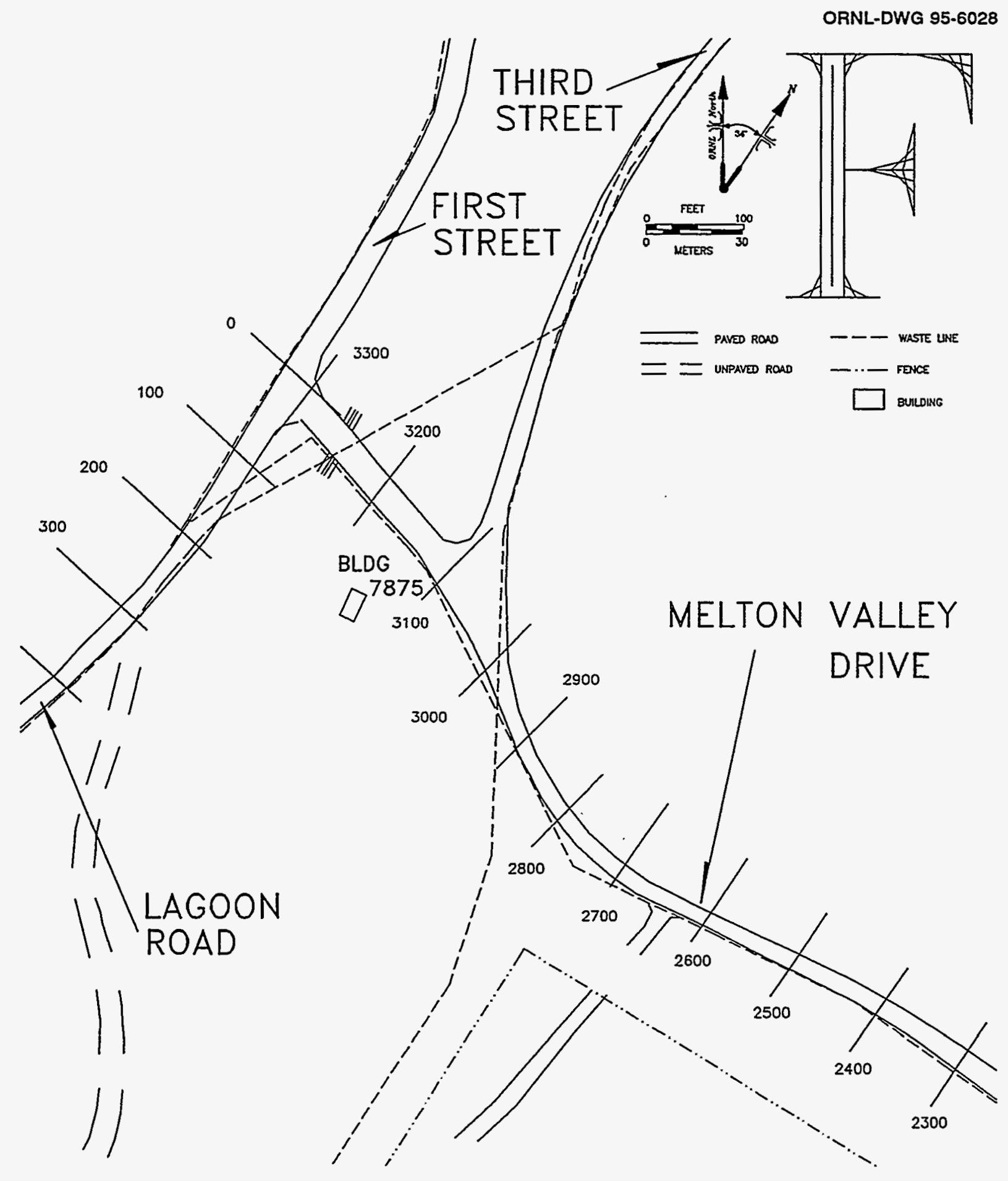

Fig. C.5. Diagram showing 100-ft grid established near the intersection of Lagoon Road and Melton Valley Drive (Section F). 

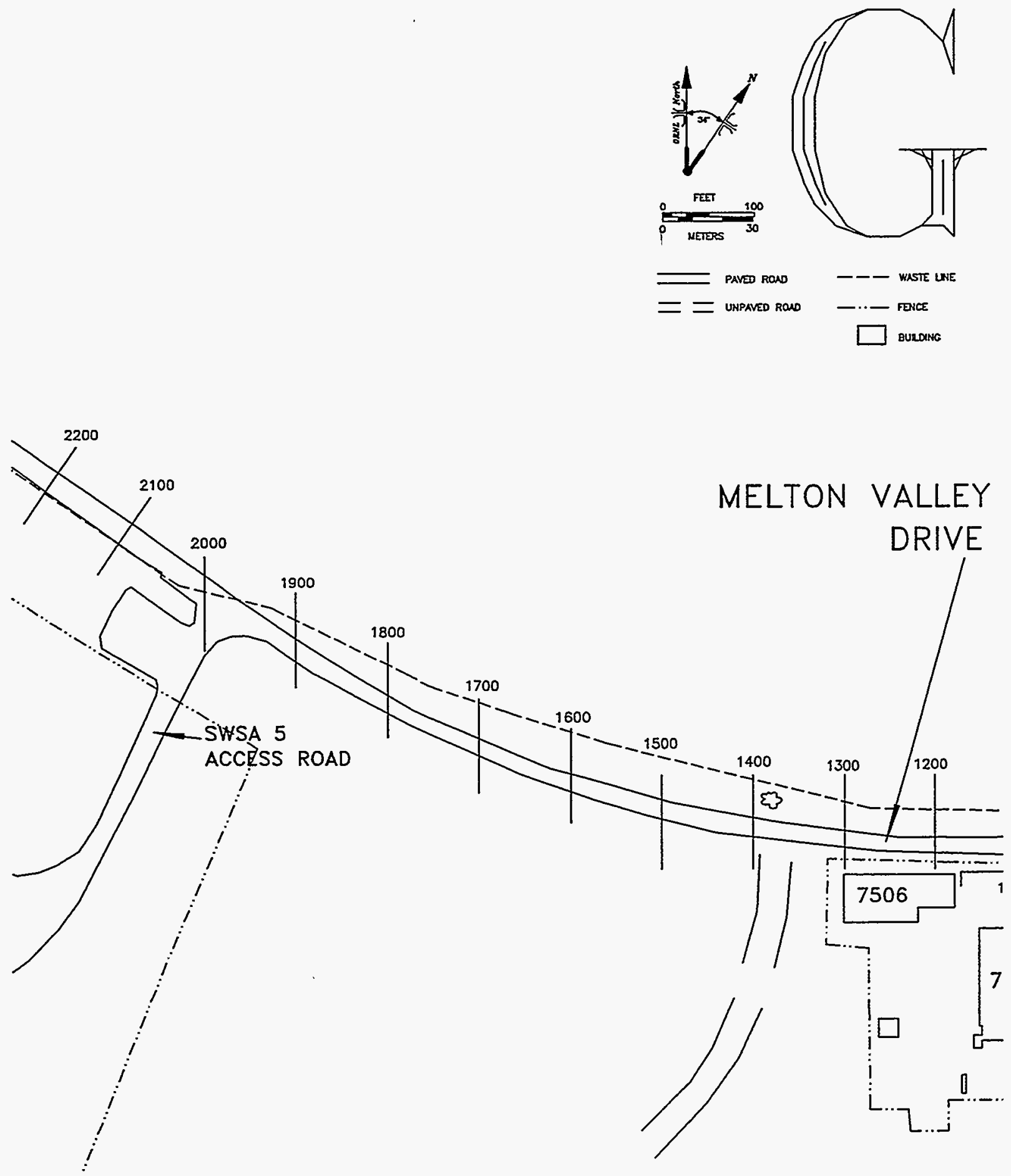

Fig. C.6. Diagram showing 100-ft grid established along a portion of Melton Valley Drive (Section G). 


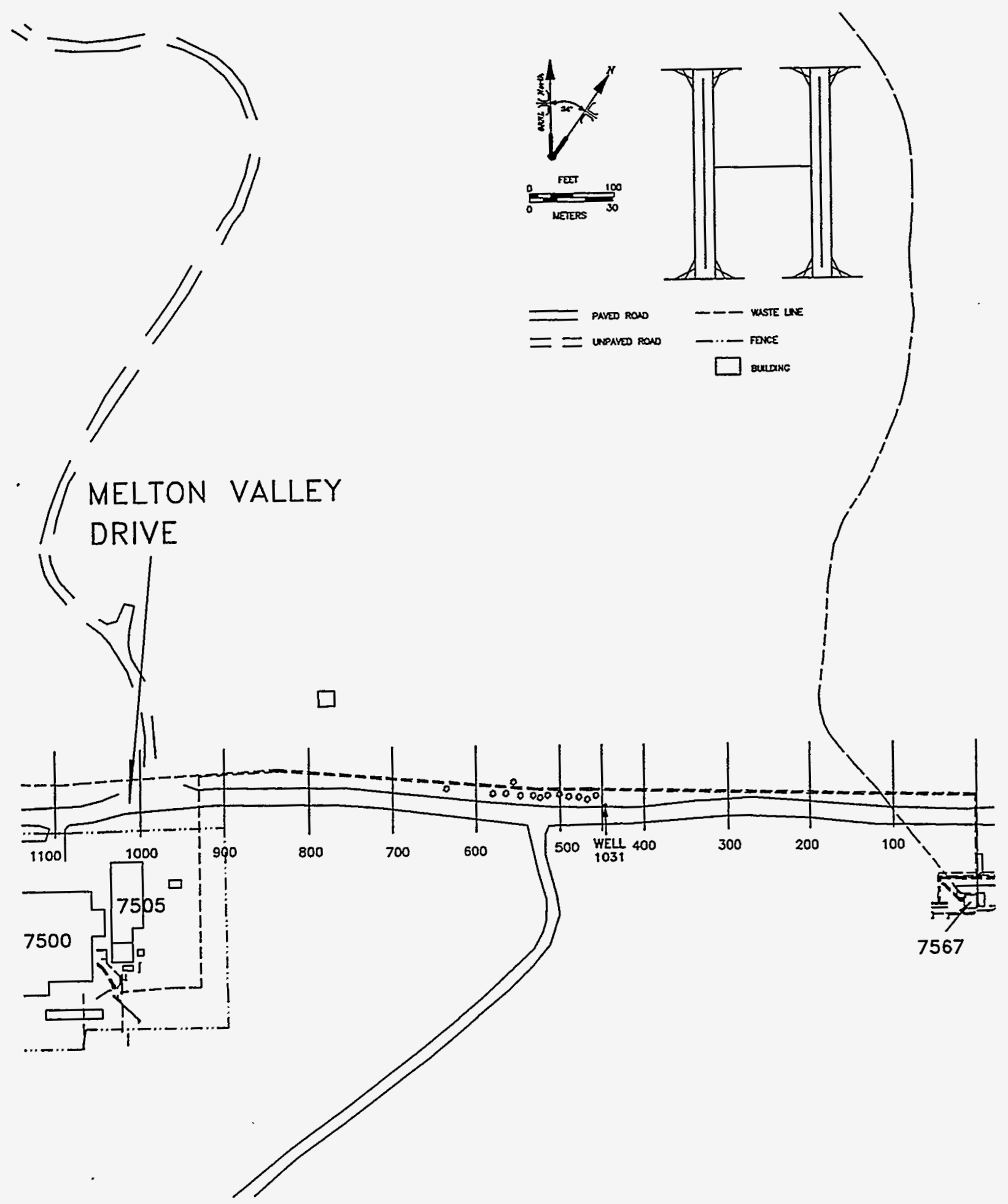

Fig. C.7. Diagram showing 100-ft grid established along a portion of Melton Valley Drive (Section H). 

Appendix D

RESULTS OF RADIONUCLIDE ANALYSIS OF ENVIRONMENTAL SAMPLES COLLECTED ALONG STATE HIGHWAY 95, LAGOON ROAD, AND

MELTON VALLEY DRIVE 


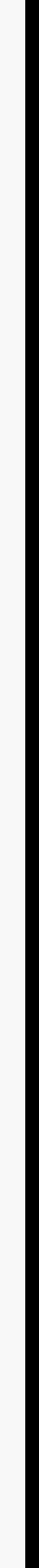


Table D.1. Concentrations of ${ }^{60} \mathrm{Co},{ }^{137} \mathrm{Cs}$, gross alpha activity, gross beta activit collected along State Highway 95, Lagoon Road, and

\begin{tabular}{|c|c|c|c|c|c|c|}
\hline \multirow{2}{*}{$\begin{array}{l}\text { Sample } \\
\text { ID }\end{array}$} & \multirow{2}{*}{$\begin{array}{l}\text { Sample } \\
\text { depth } \\
\text { (in.) }\end{array}$} & \multirow{2}{*}{$\begin{array}{c}\text { Gamma exposure } \\
\text { rate } \\
(\mu \mathrm{R} / \mathrm{h})\end{array}$} & \multirow{2}{*}{$\begin{array}{l}\text { Surface } \\
\text { beta-gamma } \\
\text { dose rate } \\
(\mathrm{mrad} / \mathrm{h})\end{array}$} & \multicolumn{3}{|c|}{ Concentration [ $\mathrm{pCi}$ /g dry weight (soil anc } \\
\hline & & & & ${ }^{60} \mathrm{Co}$ & ${ }^{137} \mathrm{Cs}$ & Gross alf \\
\hline $\mathrm{B}^{\mathrm{a}}$ & $0-2$ & $\begin{array}{l}23 \text { at surface } \\
38 \text { at depth of } 2 \text { in. }\end{array}$ & $b$ & $-0.05 \pm 0.20$ & $\frac{26 \pm 1}{(\sim 11)^{c}}$ & $11 \pm$ \\
\hline B2 & $0-6$ & $\begin{array}{l}14 \text { at } 1 \mathrm{~m} \\
16 \text { at surface } \\
16 \text { at depth of } 6 \text { in. }\end{array}$ & $b$ & $0.04 \pm 0.05$ & $9.6 \pm 0.4$ & $12 \pm$ \\
\hline B3A & $0-2$ & $\begin{array}{l}14 \text { at } 1 \mathrm{~m} \\
27 \text { at surface }\end{array}$ & 0.06 & $1.2 \pm 0.1^{d}$ & $320 \pm 30^{d}$ & $26 \pm$ \\
\hline B3B & $2-4$ & $\begin{array}{l}27 \text { at depth of } 2 \text { in. } \\
29 \text { at depth of } 4 \text { in. }\end{array}$ & 0.08 & $0.7 \pm 0.4^{d}$ & $165 \pm 3^{d}$ & $18 \pm$ \\
\hline B4A & $0-3$ & $\begin{array}{l}65 \text { at } 1 \mathrm{~m} \\
90 \text { at surface } \\
150 \text { at depth of } 3 \text { in. }\end{array}$ & 0.17 & $1.0 \pm 0.2^{d}$ & $\begin{array}{c}190 \pm 3^{d} \\
(\sim 44,000)^{c}\end{array}$ & $6 \pm$ \\
\hline B4B & $3-6$ & $\begin{array}{l}150 \text { at depth of } 3 \text { in. } \\
200 \text { at depth of } 6 \text { in. }\end{array}$ & $b$ & $4.0 \pm 0.3^{d}$ & $\begin{array}{c}950 \pm 30^{d} \\
(\sim 270,000)^{c}\end{array}$ & $27 \pm$ \\
\hline
\end{tabular}



is alpha activity, gross beta activity, ${ }^{40} \mathrm{~K}$, and strontinm in environmental samples : Highway 95, Lagoon Road, and Melton Valley Drive

tration [pCi/g dry weight (soil and vegetation samples) or $\mathrm{pCi} / \mathrm{L}$ (water samples)]

\begin{tabular}{|c|c|c|c|c|c|}
\hline${ }^{137} \mathrm{Cs}$ & Gross alpha & Gross beta & ${ }^{40} \mathrm{~K}$ & Total Sr & Comments \\
\hline$\frac{26 \pm 1}{(-11)^{c}}$ & $11 \pm 7$ & $70 \pm 10$ & $\begin{array}{l}22 \pm 4 \\
(-8.4)^{c}\end{array}$ & $0.30 \pm 0.2$ & $\begin{array}{l}\text { Collected } \sim 150 \mathrm{ft} W \\
\text { of } \mathrm{N} 18928, \mathrm{E} 32456 \mathrm{in} \\
100 \mathrm{ft}^{2} \text { area measuring } \\
16-23 \mu \mathrm{R} / \mathrm{h} \text { and } \\
0.03-0.05 \mathrm{mrad} / \mathrm{h}\end{array}$ \\
\hline $9.6 \pm 0.4$ & $12 \pm 10$ & $80 \pm 10$ & $24 \pm 1$ & $b$ & $\begin{array}{l}\text { Approx } 3-4 \mathrm{ft} \text { from } \\
\text { Melton Valley Road } \\
\text { and }-12 \mathrm{ft} \text { SW of B1; } \\
\text { part of large area of } \\
\text { spotty contamination } \\
\text { described for B1 }\end{array}$ \\
\hline $320 \pm 30^{d}$ & $26 \pm 10^{\circ}$ & $260 \pm 20^{\circ}$ & $12 \pm 5^{d}$ & $b$ & $\begin{array}{l}\text { Near power pole 7D3, } \\
2 \text { fi } \mathrm{N} \text { of fence; } 1-\mathrm{m} \\
\text { gamma due to shine } \\
\text { from creek }\end{array}$ \\
\hline $165 \pm 3^{d}$ & $18 \pm 9^{6}$ & $270 \pm 20^{\circ}$ & $8 \pm 2^{d}$ & $b$ & \\
\hline $\begin{array}{c}190 \pm 3^{d} \\
(-44,000)^{c}\end{array}$ & $6 \pm 2^{e}$ & $380 \pm 30^{\circ}$ & $b$ & $b$ & $\begin{array}{l}80 \mathrm{ft} E \text { of gaging } \\
\text { station (Bldg. } 7875 \text { ) } \\
\text { and } 15 \mathrm{ft} S \text { of Melton } \\
\text { Valley Road }\end{array}$ \\
\hline $\begin{array}{c}950 \pm 30^{d} \\
(-270,000)^{c}\end{array}$ & $27 \pm 0.3^{e}$ & $730 \pm 50^{e}$ & $b$ & $b$ & \\
\hline
\end{tabular}



Table D.1 (co:

\begin{tabular}{|c|c|c|c|c|c|}
\hline \multirow[b]{2}{*}{$\begin{array}{l}\text { Sample } \\
\text { ID }\end{array}$} & \multirow{2}{*}{$\begin{array}{l}\text { Sample } \\
\text { depth } \\
\text { (in.) } \\
\end{array}$} & \multirow{2}{*}{$\begin{array}{c}\text { Gamma exposure } \\
\text { rate } \\
(\mu \mathrm{R} / \mathrm{h}) \\
\end{array}$} & \multirow{2}{*}{$\begin{array}{c}\text { Surface } \\
\text { beta-gamma } \\
\text { dose rate } \\
(\mathrm{mrad} / \mathrm{h})\end{array}$} & \multicolumn{2}{|c|}{ Concentration [pCi/g dry we } \\
\hline & & & & ${ }^{60} \mathrm{Co}$ & ${ }^{137} \mathrm{Cs}$ \\
\hline B6 & $0-4$ & $\begin{array}{l}15 \text { at } 1 \mathrm{~m} \\
16 \text { at surface }\end{array}$ & $\begin{array}{c}0.92 \\
(0.15 \text { at depth } \\
\text { of } 4 \text { in.) }\end{array}$ & $0.04 \pm 0.09^{d}$ & $0.4 \pm 0.1^{d}$ \\
\hline B7 & $b$ & $\begin{array}{l}15 \text { at } 1 \mathrm{~m} \\
12 \text { at surface }\end{array}$ & $b$ & $0.03 \pm 0.05^{d}$ & $7.6 \pm 0.3^{d}$ \\
\hline B8 & $0-3$ & $\begin{array}{l}250 \text { at } 1 \mathrm{~m} \\
400 \text { at surface } \\
550 \text { at depth of } 3 \text { in. }\end{array}$ & 0.70 & $\begin{array}{c}4.7 \pm 0.4^{d} \\
(\sim 0.6 \pm 20 \%)^{c}\end{array}$ & $\begin{aligned} 2,000 & \pm 40^{d} \\
(-320 & \pm 0.62 \%)^{c}\end{aligned}$ \\
\hline B9 & $b$ & $\begin{array}{l}2,000 \text { at } 1 \mathrm{~m} \\
15,000 \text { at surface }\end{array}$ & 11.78 & $0.65 \pm 2$ & $\begin{aligned} 10,000 & \pm 300 \\
(-3,500 & \pm 10)^{c}\end{aligned}$ \\
\hline B10 & $b$ & 15 at surface & 0.65 & $0.1 \pm 0.1^{d}$ & $21 \pm 1^{d}$ \\
\hline B11 & $0-4$ & $\begin{array}{l}14 \text { at } 1 \mathrm{~m} \\
40 \text { at surface } \\
125 \text { at depth of } 4 \text { in. }\end{array}$ & 0.10 & $b$ & $(-400)^{c}$ \\
\hline B12 & $0-2$ & $\begin{array}{l}14 \text { at } 1 \mathrm{~m} \\
100 \text { at surface }\end{array}$ & 0.87 & $(\sim 500,000)^{c}$ & $b$ \\
\hline $\mathrm{B} 13 \mathrm{~s}$ & $0-3$ & $\begin{array}{l}4 \text { at } 1 \mathrm{~m} \\
14 \text { at surface }\end{array}$ & 0.71 & $b$ & $200 \pm 3$ \\
\hline
\end{tabular}




(2)


ght (soil and vegetation samples) or $\mathrm{pCi} / \mathrm{L}$ (water samples)]

\begin{tabular}{ccccc}
\hline Gross alpha & Gross beta & $40 \mathrm{~K}$ & Total Sr & Comments \\
\hline $3 \pm 1^{e}$ & $24 \pm 2^{e}$ & $5 \pm 1^{d}$ & $.10 \pm 2^{f}$ & \\
$4 \pm 1^{e}$ & $130 \pm 5^{e}:$ & $8 \pm 1^{d}$ & $b$ & $\begin{array}{l}\text { Sediment and debris } \\
\text { at end of drainage } \\
\text { area }\end{array}$
\end{tabular}

$47 \pm 16^{c} \quad 1,900 \pm 40^{c} \quad 16 \pm 3^{d} \quad b$

$\begin{array}{lllll}9.7 \pm 10 & 9,500 \pm 300 & 13 \pm 3 & 43 \pm 8 & \begin{array}{l}\text { Collected near } \\ \text { concrete slab }\end{array}\end{array}$

$6 \pm 2^{e}$

$320 \pm 30^{\circ}$

$5 \pm 2^{d} \quad 150 \pm 5^{f}$

$b$

$b$

$b$

$b$

$b$

$b$

Collected adjacent to B6 to verify analytical results on that sample

From $70-\times 4$ ft area beside Lagoon Road measuring 12 to $40 \mu \mathrm{R} / \mathrm{h}$

All contamination removed with sample. Gamma at $1 \mathrm{~m}$ after sampling $=12 \mu R / h$
$5.9 \pm 0.5 \quad 230 \pm 250$
$27 \pm 49$
$760 \pm 30$

Aliquot of sample. Small particie $e^{h^{2}}$ $(\sim 23 \mathrm{mrad} / \mathrm{h})$ isolated from sample 


\begin{tabular}{|c|c|c|c|c|c|}
\hline \multirow{2}{*}{$\begin{array}{l}\text { Sample } \\
\text { ID }\end{array}$} & \multirow{2}{*}{$\begin{array}{l}\text { Sample } \\
\text { depth } \\
\text { (in.) }\end{array}$} & \multirow{2}{*}{$\begin{array}{c}\text { Gamma exposure } \\
\text { rate } \\
(\mu \mathrm{R} / \mathrm{h})\end{array}$} & \multirow{2}{*}{$\begin{array}{l}\text { Surface } \\
\text { beta-gamma } \\
\text { dose rate } \\
\text { (mrad/h) }\end{array}$} & \multicolumn{2}{|c|}{ Concentratior } \\
\hline & & & & ${ }^{60} \mathrm{Co}$ & $13^{\circ}$ \\
\hline $\mathrm{B} 14^{i}$ & $0-4$ & $\begin{array}{l}15 \text { at } 1 \mathrm{~m} \\
100 \text { at surface }\end{array}$ & 0.19 & $b$ & $\begin{array}{r}1,50 \\
(\sim\end{array}$ \\
\hline $\mathrm{B} 15^{\mathrm{j}}$ & $0-4$ & $\begin{array}{l}10 \text { at } 1 \mathrm{~m} \\
100 \text { at surface }\end{array}$ & $b$ & $b$ & $\begin{array}{l}70 \\
(\sim ;\end{array}$ \\
\hline $\mathrm{B} 16^{k}$ & & 20 at surface & $b$ & $-0.1 \pm 0.1^{d}$ & 5 \\
\hline $\mathrm{B} 17^{l}$ & $\mathrm{NA}^{m}$ & $b$ & 0.53 & $b$ & 17,00 \\
\hline $\mathrm{V} 1$ & $\mathrm{NA}^{m}$ & $\begin{array}{l}14 \text { at } 1 \mathrm{~m} \\
15 \text { at surface }\end{array}$ & 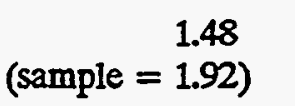 & $0.03 \pm 0.43$ & c \\
\hline $\mathrm{V} 2$ & $\mathrm{NA}^{m}$ & $b$ & 0.12 & $0.05 \pm 0.70^{d}$ & : \\
\hline W1 & $\mathrm{NA}^{m}$ & $\begin{array}{l}13 \text { at } 1 \mathrm{~m} \\
13 \text { at surface }\end{array}$ & 0.06 & $2.4 \pm 7.3^{d}$ & -0 \\
\hline
\end{tabular}





\section{[able D.1 (continued)}

[pCi/g dry weight (soil and vegetation samples) or $\mathrm{pCi} / \mathrm{L}$ (water samples)]

\begin{tabular}{|c|c|c|c|c|c|c|c|c|c|}
\hline \multirow{2}{*}{$\frac{C s}{ \pm 140}$} & \multirow{2}{*}{\multicolumn{2}{|c|}{$\frac{\text { Gross alpha }}{0.5 \pm 2.2}$}} & \multicolumn{2}{|l|}{ Gross beta } & \multicolumn{2}{|c|}{${ }^{40} \mathrm{~K}$} & \multicolumn{2}{|c|}{ Total Sr } & \multirow[t]{2}{*}{ Comments } \\
\hline & & & $52 \pm$ & 7 & 26 & \pm 4 & $26 \pm$ & 4 & \\
\hline \pm 10 & & $8 \pm 1.5$ & $14 \pm$ & 4 & 21 & \pm 4 & $3.4 \pm$ & 0.6 & \\
\hline $\pm 3^{d}$ & & $\pm 1^{e}$ & $35 \pm$ & $3^{e}$ & & $\pm 2^{d}$ & $0.1 \pm$ & $0.1^{f}$ & $\begin{array}{l}\text { Sample from west side } \\
\text { of State Highway } 95\end{array}$ \\
\hline \pm 300 & -19 & \pm 50 & $100,000 \pm 3$ &, 000 & $b$ & & $38,000 \pm 3$ &, 000 & $\begin{array}{l}\text { Apparently pieces of } \\
\text { yellow tape, measured } \\
4.8 \mathrm{mrad} / \mathrm{h}\end{array}$ \\
\hline $1 \pm 0.4$ & 2 & \pm 2 & $1,900 \pm$ & 30 & 2 & $b$ & $b$ & & $\begin{array}{l}\text { Pieces of dead tree } \\
\text { limbs and twigs found } \\
\text { on ground. Approx. } 15 \\
\mathrm{ft} N \text { of } \mathrm{MW}-1031 \\
\text { inside } 10-\times 15-\mathrm{ft} \text { area } \\
\text { ranging from } 0.06 \text { to } \\
1.5 \mathrm{mrad} / \mathrm{h}, \mathrm{N} \text { of } \\
\text { Melton Valley Road }\end{array}$ \\
\hline $\pm 1^{d}$ & & $b$ & $b$ & & $i$ & & $211 \pm$ & & $\begin{array}{l}\text { Tree branch taken } \\
\text { from tree measuring } \\
1.06 \mathrm{mrad} / \mathrm{h} \text { located } \\
\text { west of Bldg. } 7819\end{array}$ \\
\hline $\pm 6.8^{d}$ & & $\pm 2^{e}$ & $2,700 \pm 2$ & & $b$ & & $1,400 \pm 8$ & & $\begin{array}{l}\text { Sample taken as water } \\
\text { entered culvert near } \\
\text { leaves on grating } \\
\text { measuring } 1.2 \mathrm{mrad} / \mathrm{h}\end{array}$ \\
\hline
\end{tabular}


Table D.1 (contineei

\begin{tabular}{|c|c|c|c|c|c|c|}
\hline \multirow{2}{*}{$\begin{array}{l}\text { Sample } \\
\text { ID }\end{array}$} & \multirow{2}{*}{$\begin{array}{c}\text { Sample } \\
\text { depth } \\
\text { (in.) } \\
\end{array}$} & \multirow{2}{*}{$\begin{array}{c}\text { Gamma exposure } \\
\text { rate } \\
(\mu \mathrm{R} / \mathrm{h}) \\
\end{array}$} & \multirow{2}{*}{$\begin{array}{c}\begin{array}{c}\text { Surface } \\
\text { beta-gamma } \\
\text { dose rate } \\
(\mathrm{mrad} / \mathrm{h})\end{array} \\
\end{array}$} & \multicolumn{3}{|c|}{ Concentration [pCi/g dry weight (sc } \\
\hline & & & & ${ }^{60} \mathrm{Co}$ & ${ }^{137} \mathrm{Cs}$ & Grr \\
\hline W2 & $\mathrm{NA}^{m}$ & $\begin{array}{l}13 \text { at } 1 \mathrm{~m} \\
13 \text { at surface }\end{array}$ & $0.38^{\circ}$ & $-0.3 \pm 3.8^{d}$ & $51 \pm 5^{d}$ & 1 \\
\hline W3 & $\mathrm{NA}^{m}$ & $\begin{array}{l}15 \text { at } 1 \mathrm{~m} \\
12 \text { at surface }\end{array}$ & $b$ & $2 \pm 5^{d}$ & $2 \pm 4^{d}$ & 0 \\
\hline
\end{tabular}

${ }^{a}$ Additional analyses on this sample: ${ }^{228} \mathrm{Th} 0.55 \pm 0.08 ;{ }^{230} \mathrm{Th} 0.13 \pm 0.04 ;{ }^{232} \mathrm{Th} 0.47 \pm 0.08$.

${ }^{b}$ No data.

"Gamma spectrometry screening analysis based on entire sample volume. (Results without this footnote based on ali ${ }^{d}$ Procedure No. EPA-901.1.

Procedure No. EPA-900.0.

fProcedure No. EPA-905.0.

¿Sample No. ONL019B001.

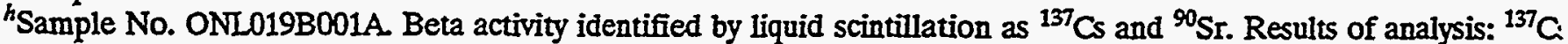
$1,900,000 \mathrm{pCi} / \mathrm{g}$.

'Sample No. ONL019SB003.

isample No. ONL019B004.

ksample No. ONL019SB005.

'Sample No. ONL015SB013.

${ }^{m}$ Not applicable.

${ }^{7}$ Concentration ${ }^{90} \mathrm{Sr}$.

${ }^{\circ}$ Measurement taken on dry asphalt. 
. 


\section{D.1 (continued)}

Ig dry weight (soil and vegetation samples) or pCi/L (water samples)]

\begin{tabular}{cccccc}
\hline & Gross alpha & Gross beta & ${ }^{40 \mathrm{~K}}$ & Total St & Comments \\
\hline $5^{d}$ & $0.9 \pm 1.6^{e}$ & $35,000 \pm 2,700^{6}$ & $b$ & $20,000 \pm 540^{\circ}$ & $\begin{array}{l}\text { Water standing on } \\
\text { asphalt near dry area } \\
\text { measuring 0.38 mrad } / \mathrm{h}\end{array}$ \\
$4^{d}$ & $0.05 \pm 0.94^{e}$ & $81 \pm 8^{e}$ & $b$ & $b$ & $\begin{array}{l}\text { Standing water at end } \\
\text { of drainage area }\end{array}$ \\
\hline
\end{tabular}

1ote based on aliquot of sample.)

; of analysis: ${ }^{137} \mathrm{Cs}, 430,000 \pm 27,000 \mathrm{pCi} / \mathrm{g}$; gross alpha, $14,000 \pm 10,000 \mathrm{pCi} / \mathrm{g}$; gross beta, $7,500,000 \pm$ 

Appendix E

PHOTOGRAPHS OF THE SURVEY AREA ALONG STATE HIGHWAY 95, LAGOON ROAD, AND

MELTON VALLEY DRIVE 


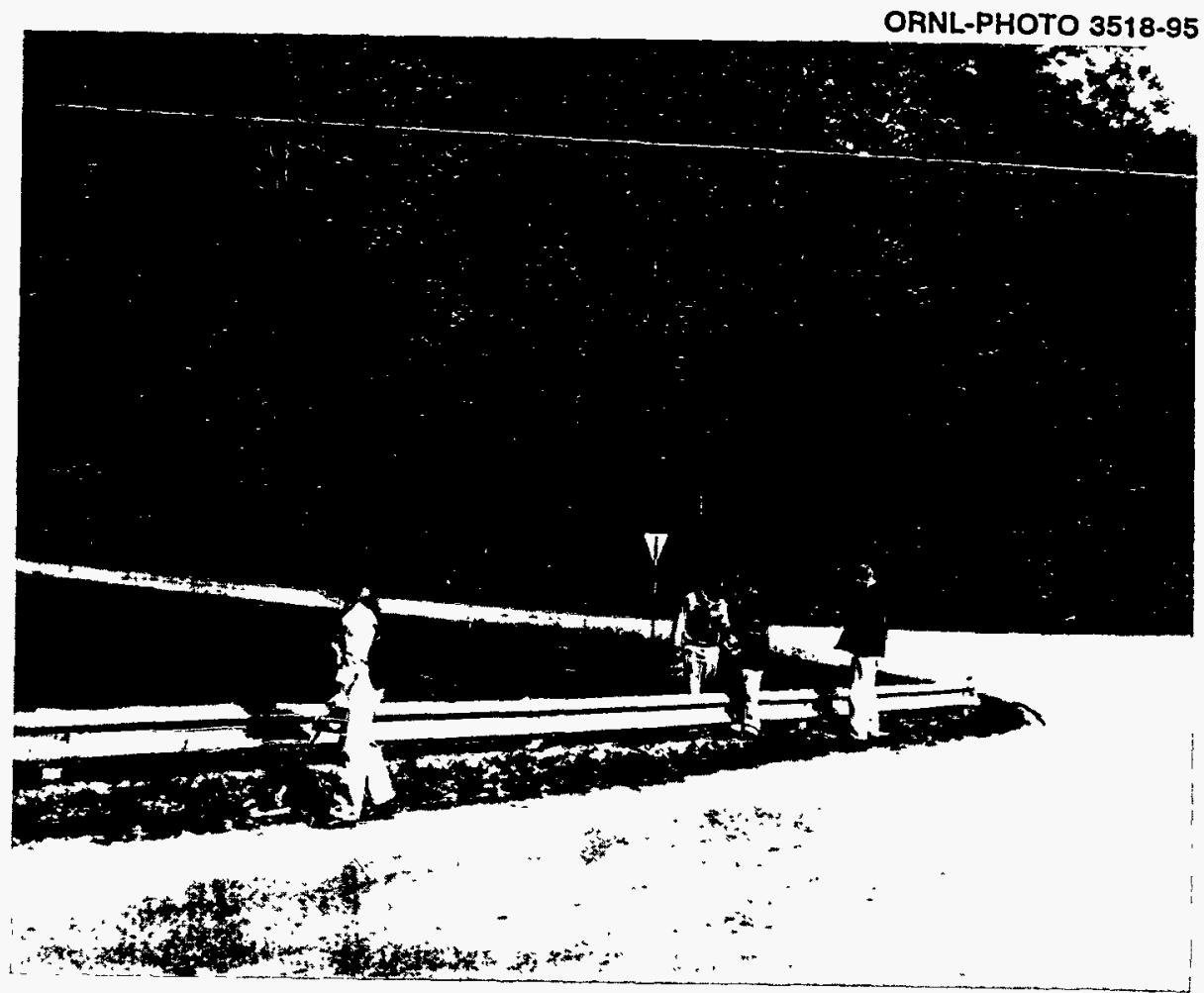

Fig. E.1. Survey crew at work. Looking northeast at the intersection of Third Street and Melton Valley Drive.

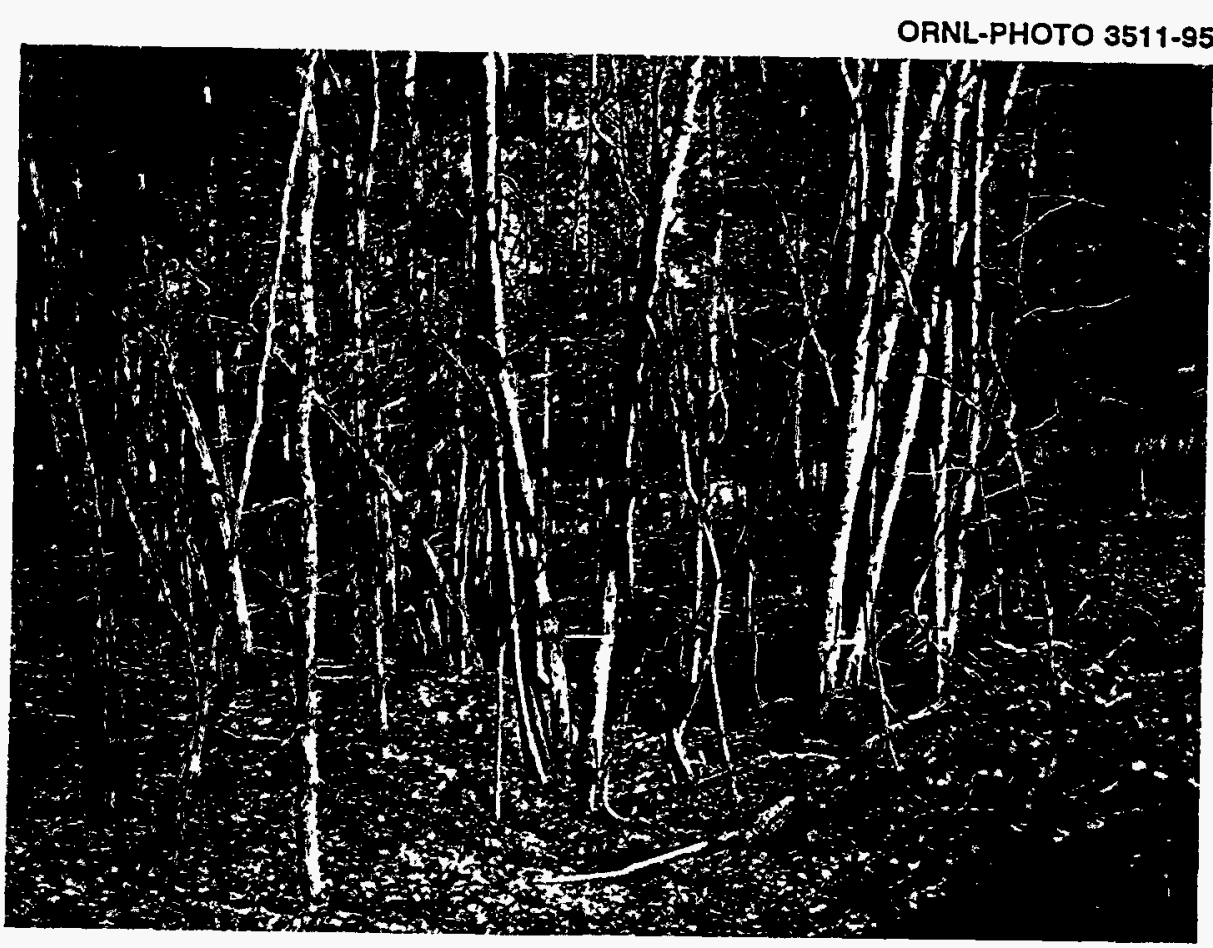

Fig. E.2. Yellow bands mark trees with elevated radiation levels (0.04 to $0.12 \mathrm{mrad} / \mathrm{h}$ ) located near a natural drainage area east of Building 7819 (Section D). 


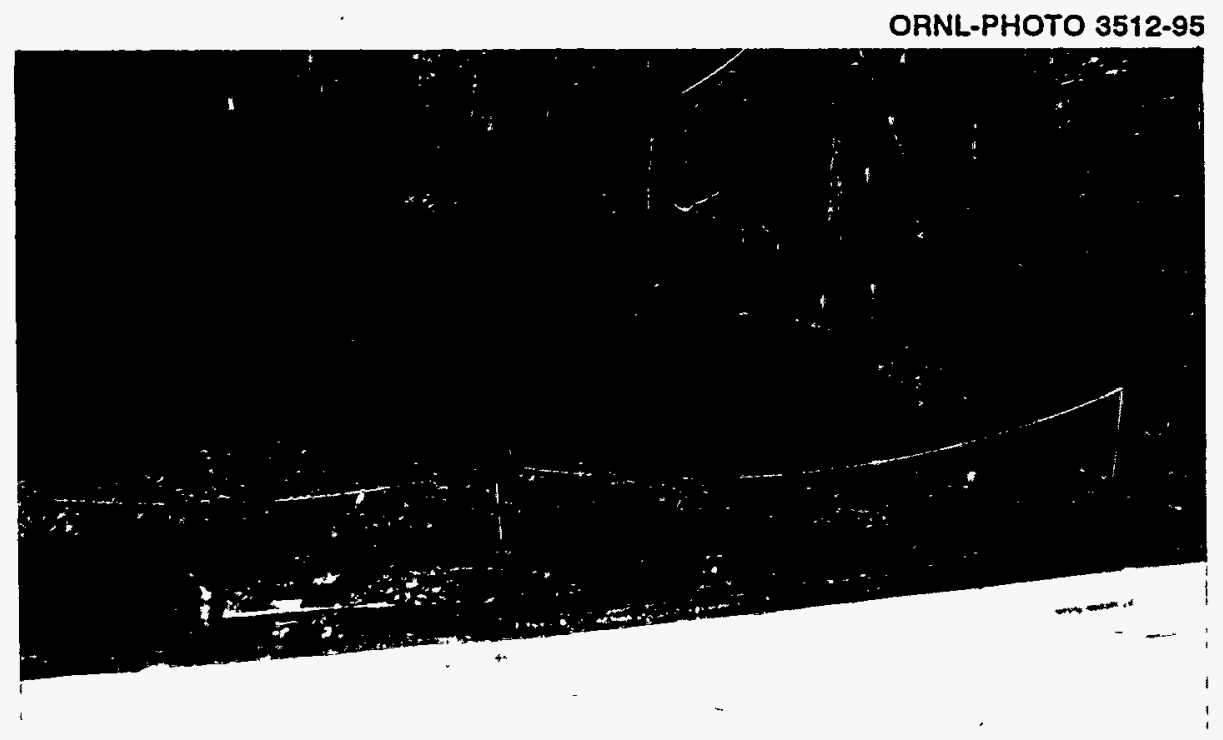

Fig. E.3. Fallen leaves from contaminated trees cover a grating at the south end of a natural drainage area along Lagoon Road (Section D).

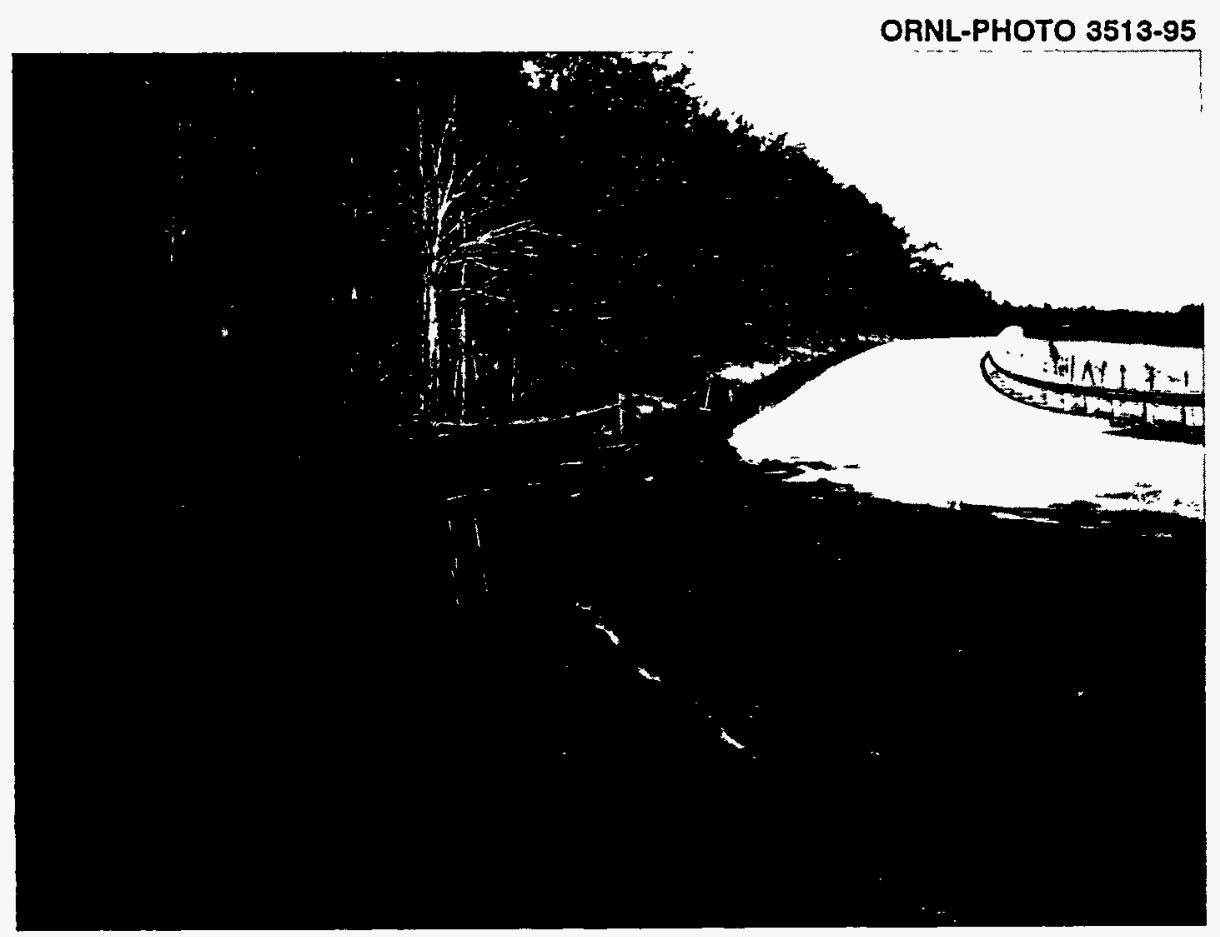

Fig. E.4. Photo showing standing water, blacktop, bank, and chained contamination area depicted in Fig. B.5. This area is located east of Building 7819, north of Lagoon Road (Section D). 
ORNL-PHOTO $3514-95$

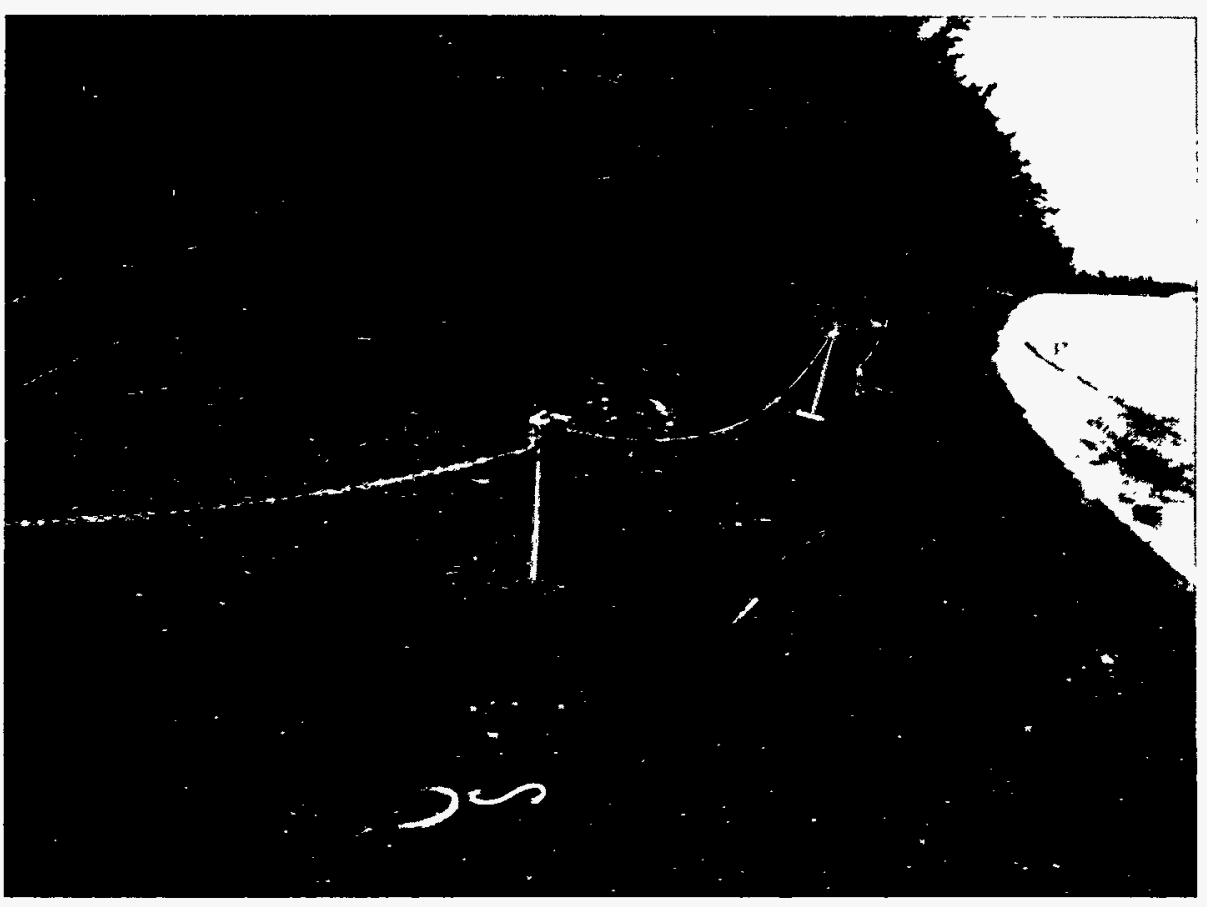

Fig. E.5. A white $\mathbf{S}$ marks the location of transferable beta-gamma activity found along Lagoon Road east of Building 7819.

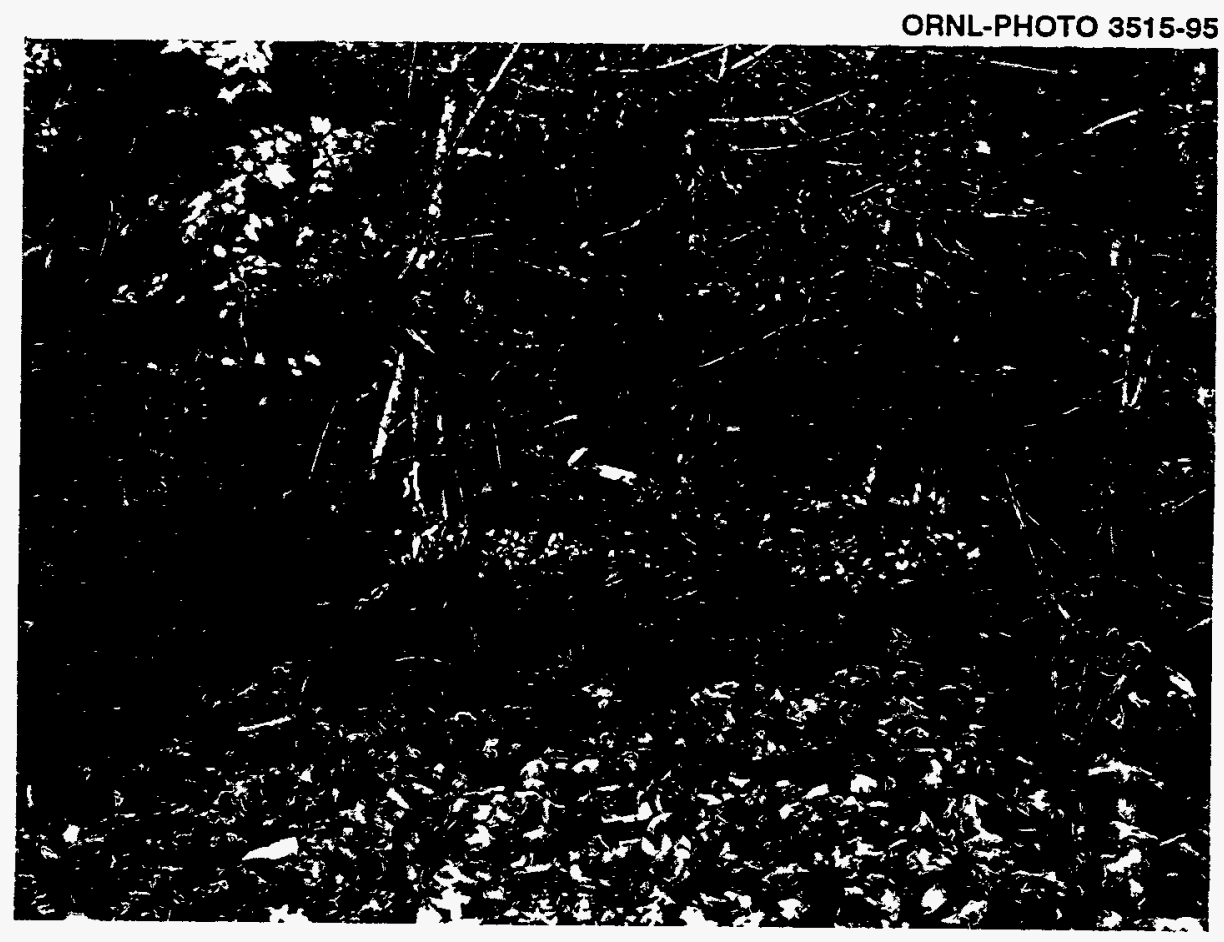

Fig. E.6. View of beta-gamma paricake probe sitting on a contaminated willow tree $(0.3 \mathrm{mrad} / \mathrm{h})$ west of Lagoon Road (Section F). 
ORNL-PHOTO 3516-95

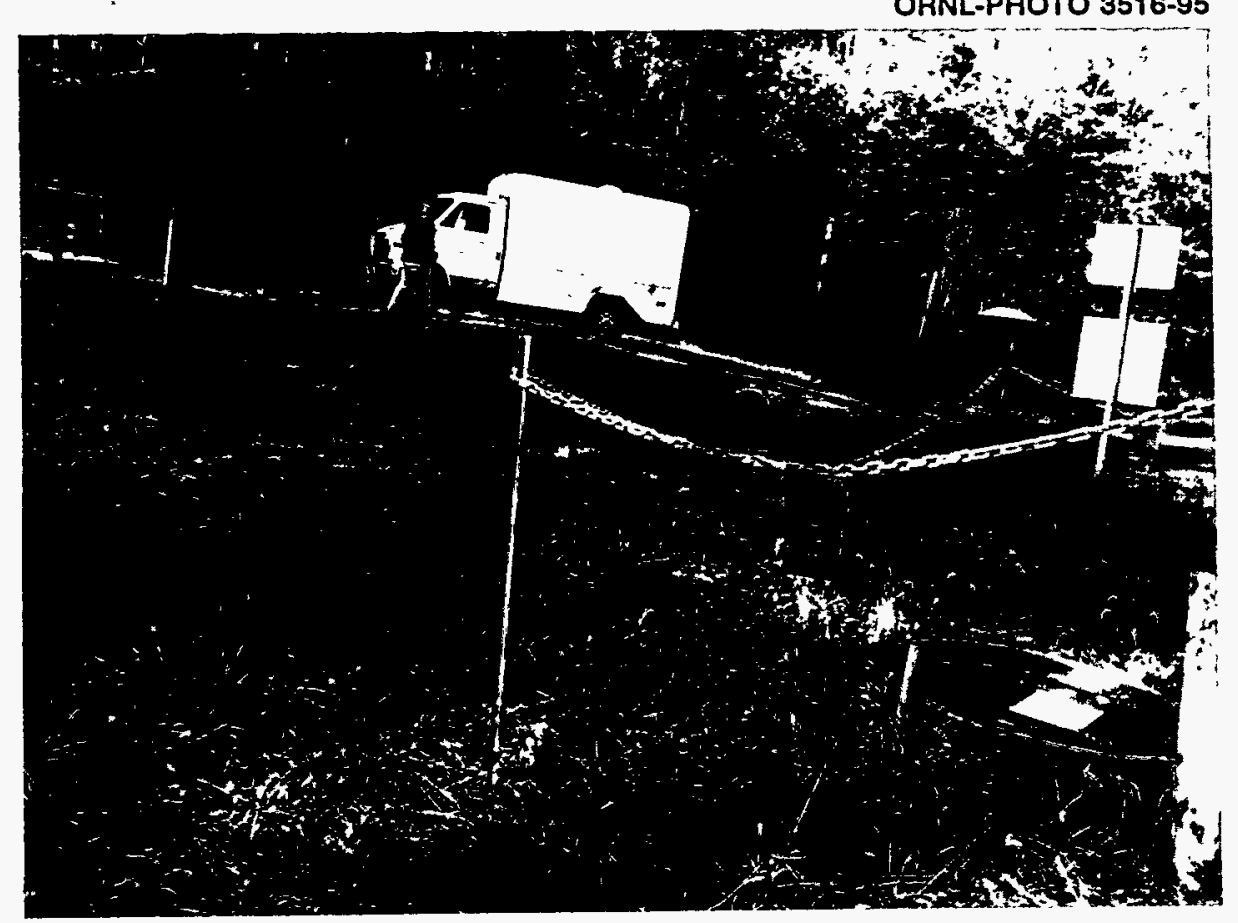

Fig. E.7. Flags marking a $2-\mathrm{ft}^{2}$ region of contamination extending outside a 6- by 18-ft posted Radiation Area west of Lagoon Road (Section F). Beta-gamma dose rates on the ground outside the rope ranged up to $0.15 \mathrm{mrad} / \mathrm{h}$.

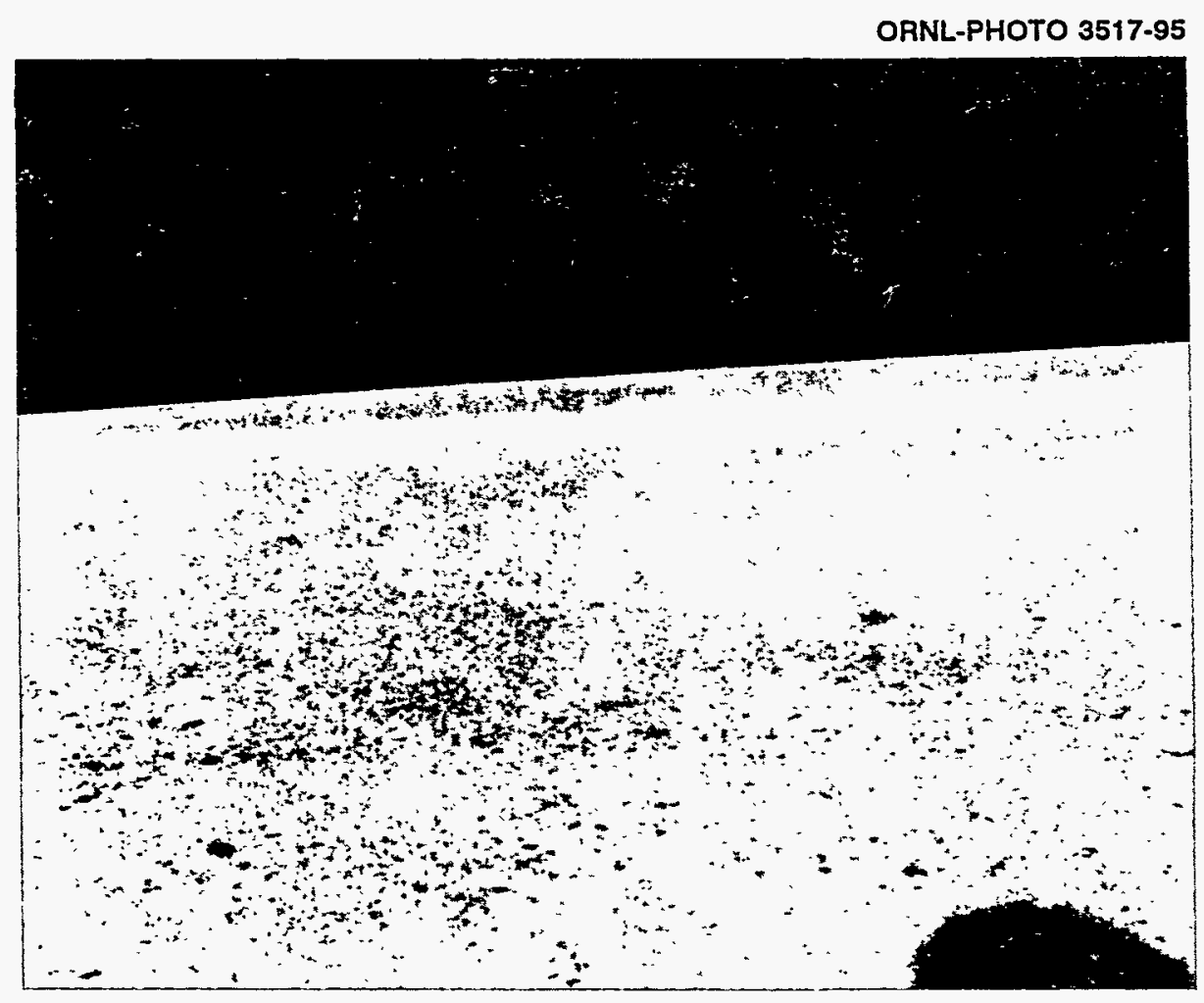

Fig. E.8. White circles mark the locations of elevated spots identified on the road surface at the intersection of Melton Valley Drive and SWSA 5 Access Road (Section G, looking north). The contamination was nontransferable. 


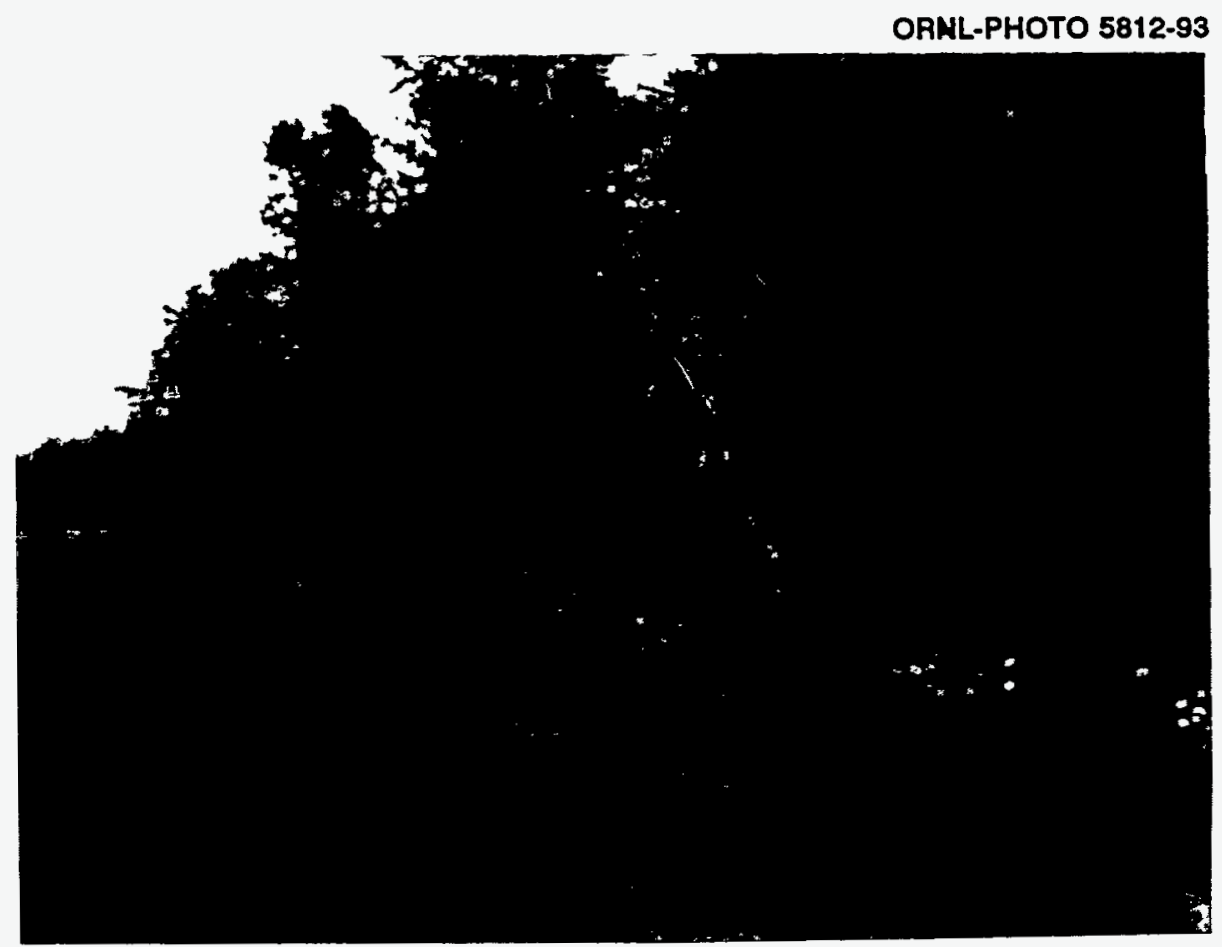

Fig. E.9. Contamination Area rope erected to enclose contaminated trees found north of Melton Valley Drive (Section H).

ORNL-PHOTO $3519-95$

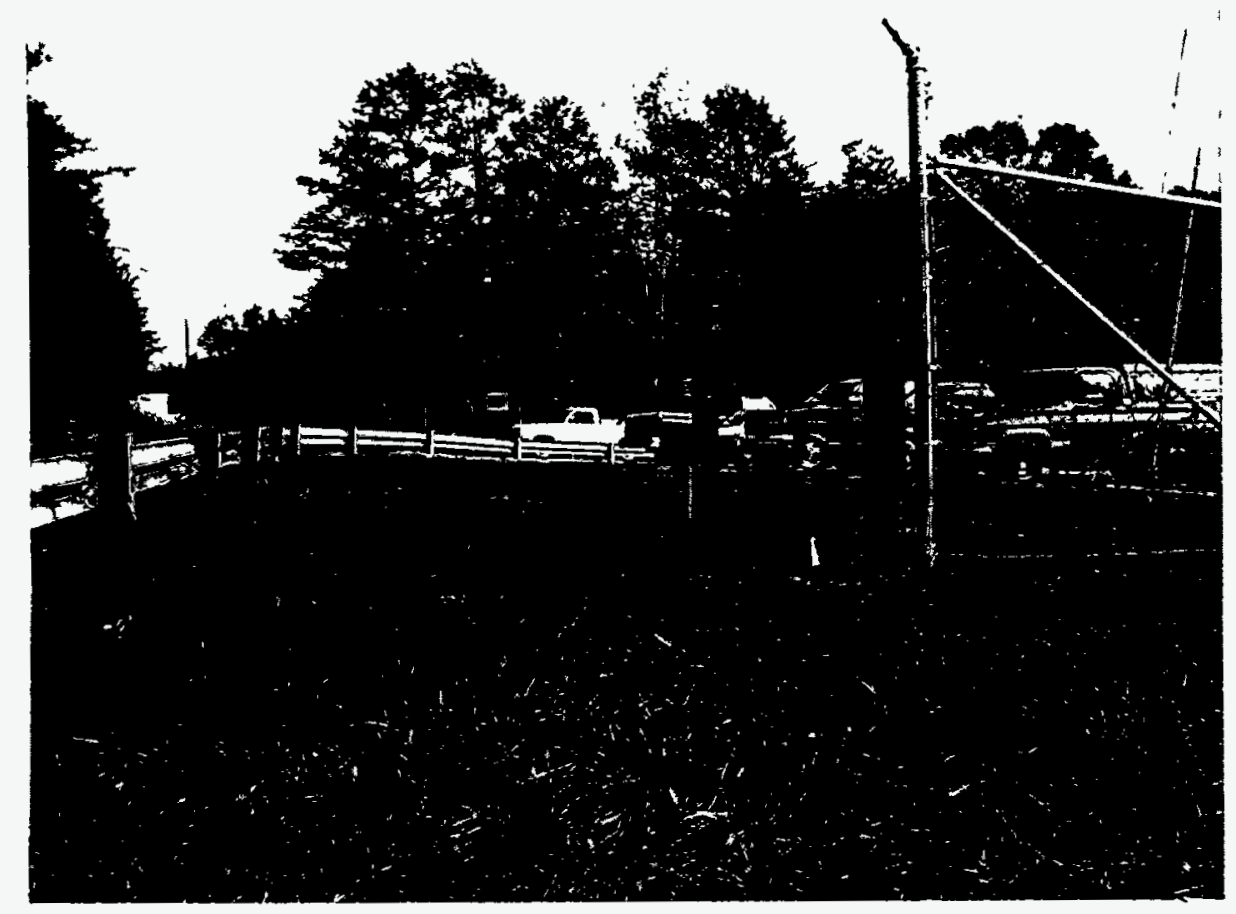

Fig. E.10. Flags mark beta-gamma anomalies (0.08 to $0.95 \mathrm{mrad} / \mathrm{h})$ in the grass west of the SWSA 5 Access Road (Section G). 


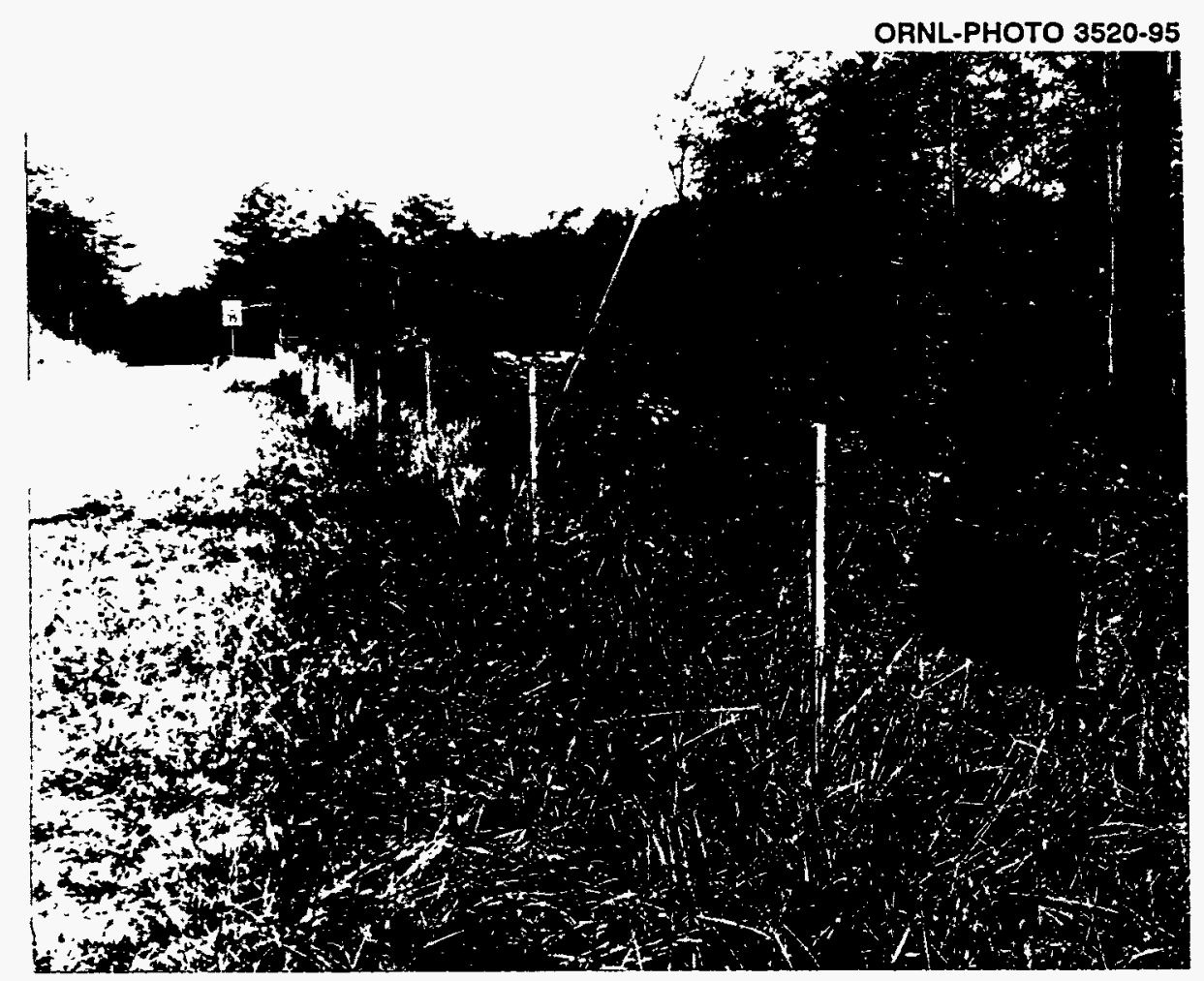

Fig. E.11. Soil sample location B3 adjacent to Melton Valley Drive (Section F).

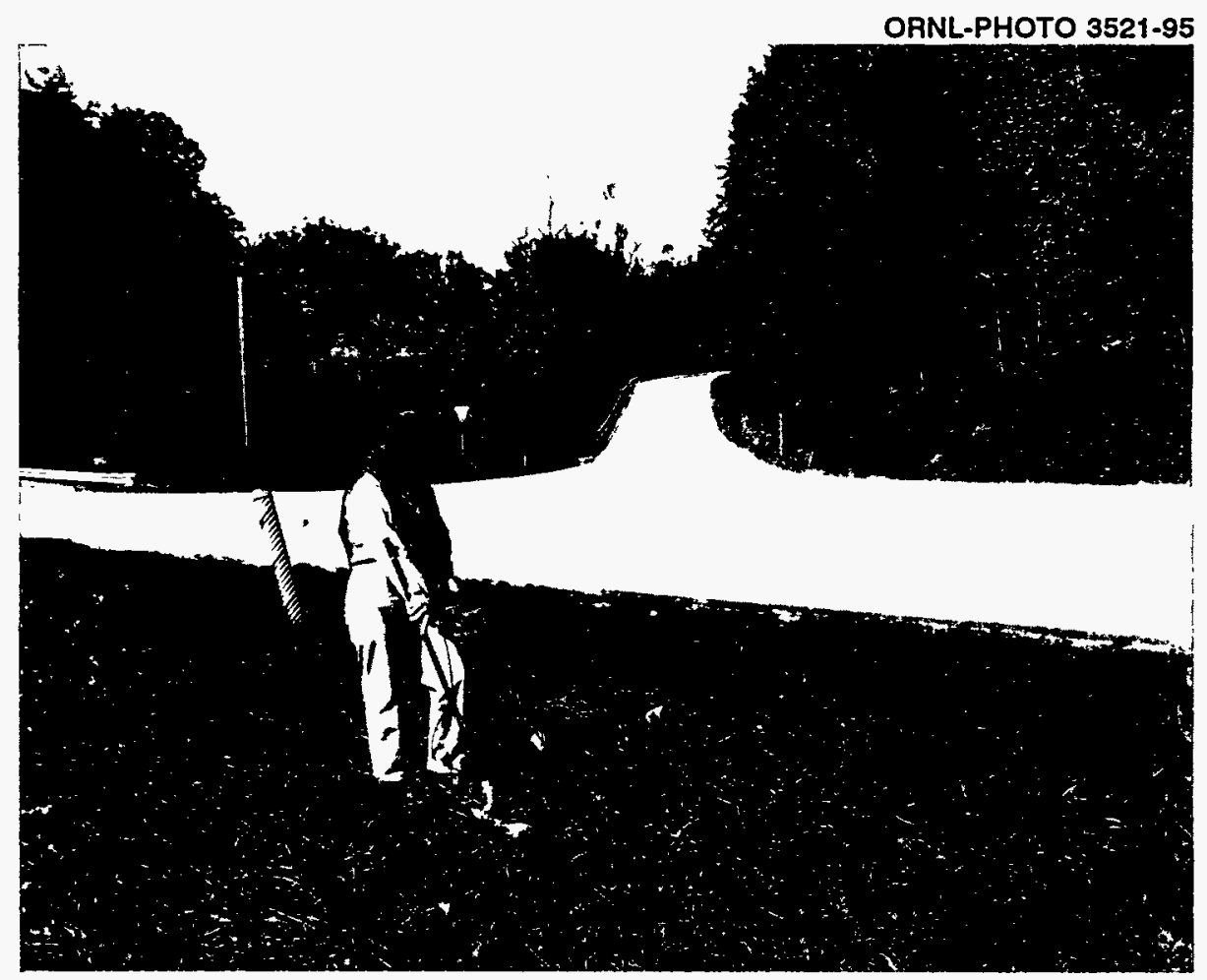

Fig. E.12. Soil sample location B4 adjacent to Melton Valley Drive (Section F). 


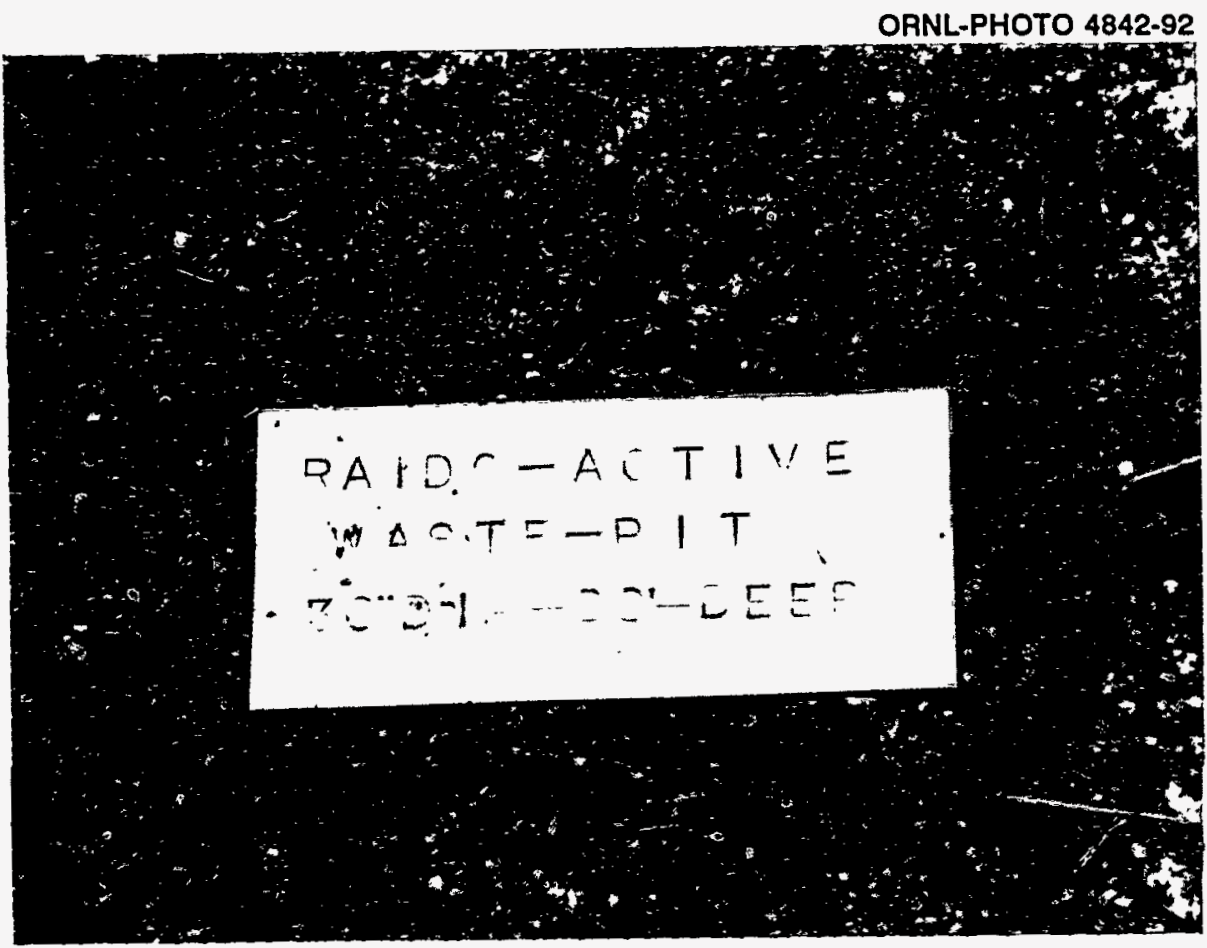

Fig. E.13. Photograph of one of several concrete waste pits near Lagoon Road and SWSA 4 proper. Note the word "radioactive" is misspelled as "raido-active" (May 1992).

ORNL-PHOTO 4843-92

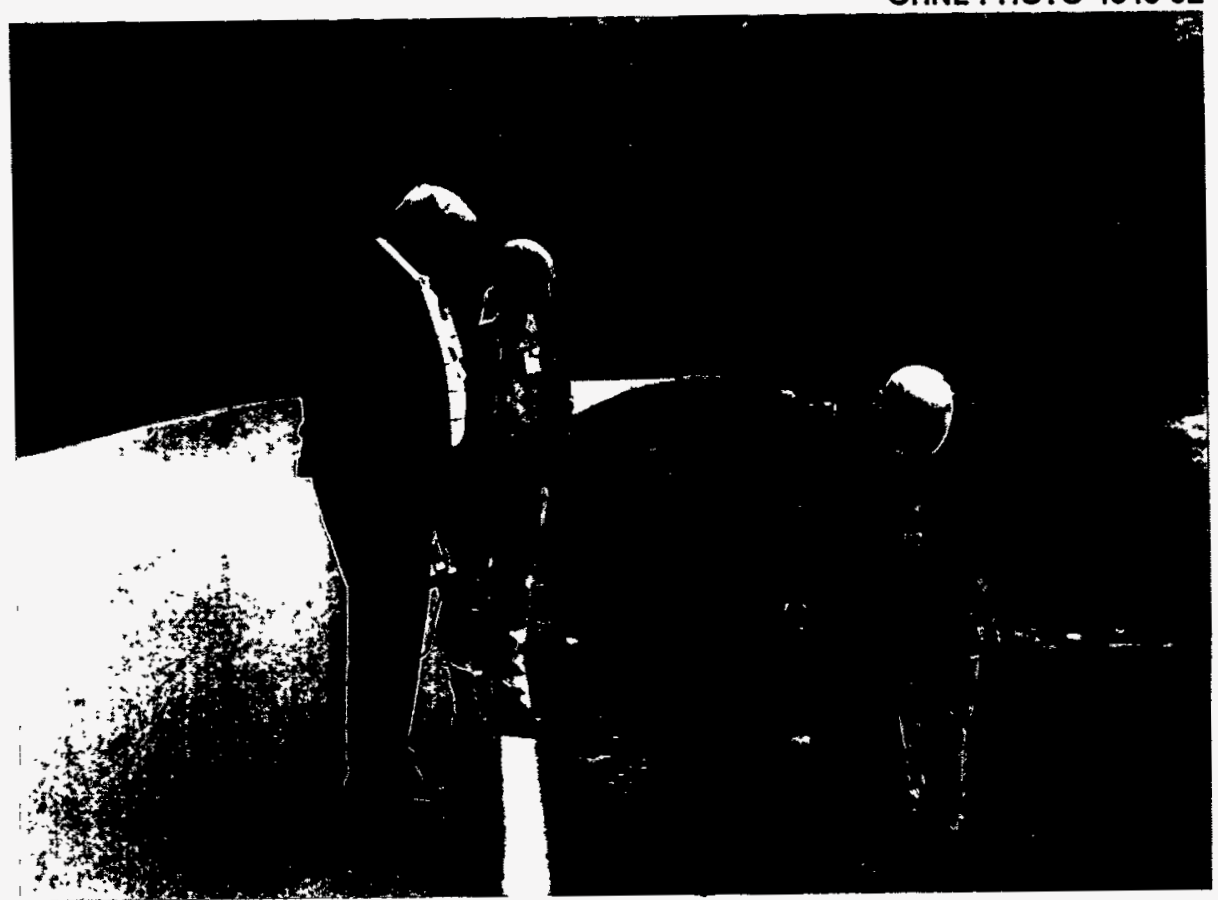

Fig. E.14. View looking east along Lagoon Road. W. D. Cottrell investigates a surface hot particle found near the road. The particle, as removed, consisted primarily of ${ }^{60} \mathrm{Co}$, total activity approximately $50 \mu \mathrm{Ci}$ (May 1992). 
ORNL-PHOTO $3522-95$

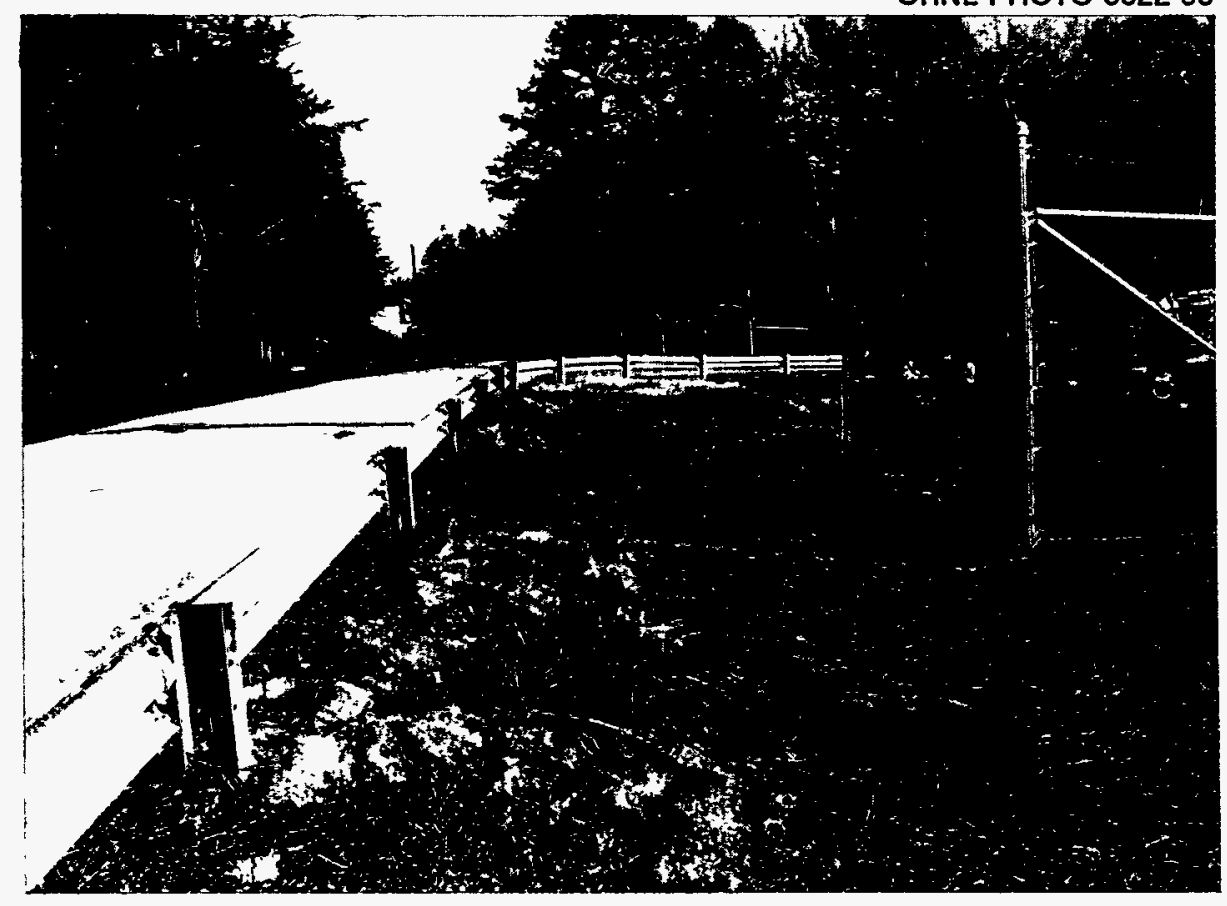

Fig. E.15. View looking east along Melton Valley Drive near entrance to SWSA 5. As an interim measure prior to cleanup, surface beta-gama radiation levels were reduced after gravel was used to cover several soil hot spots (1994).

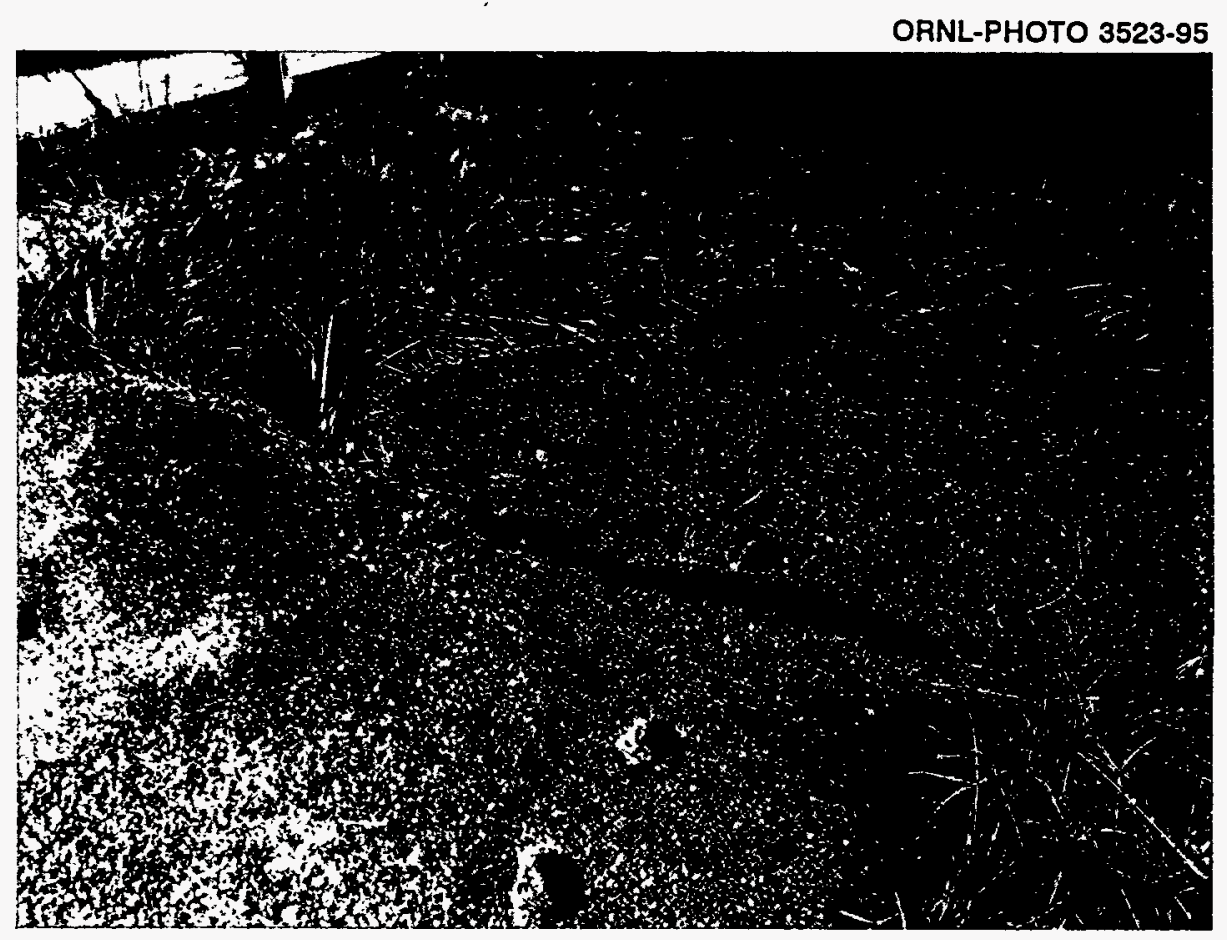

Fig. E.16. A closer view of gravel-covered soil hot spots near Melton Valley Drive. Note deer tracks across gravel surface (1994). 

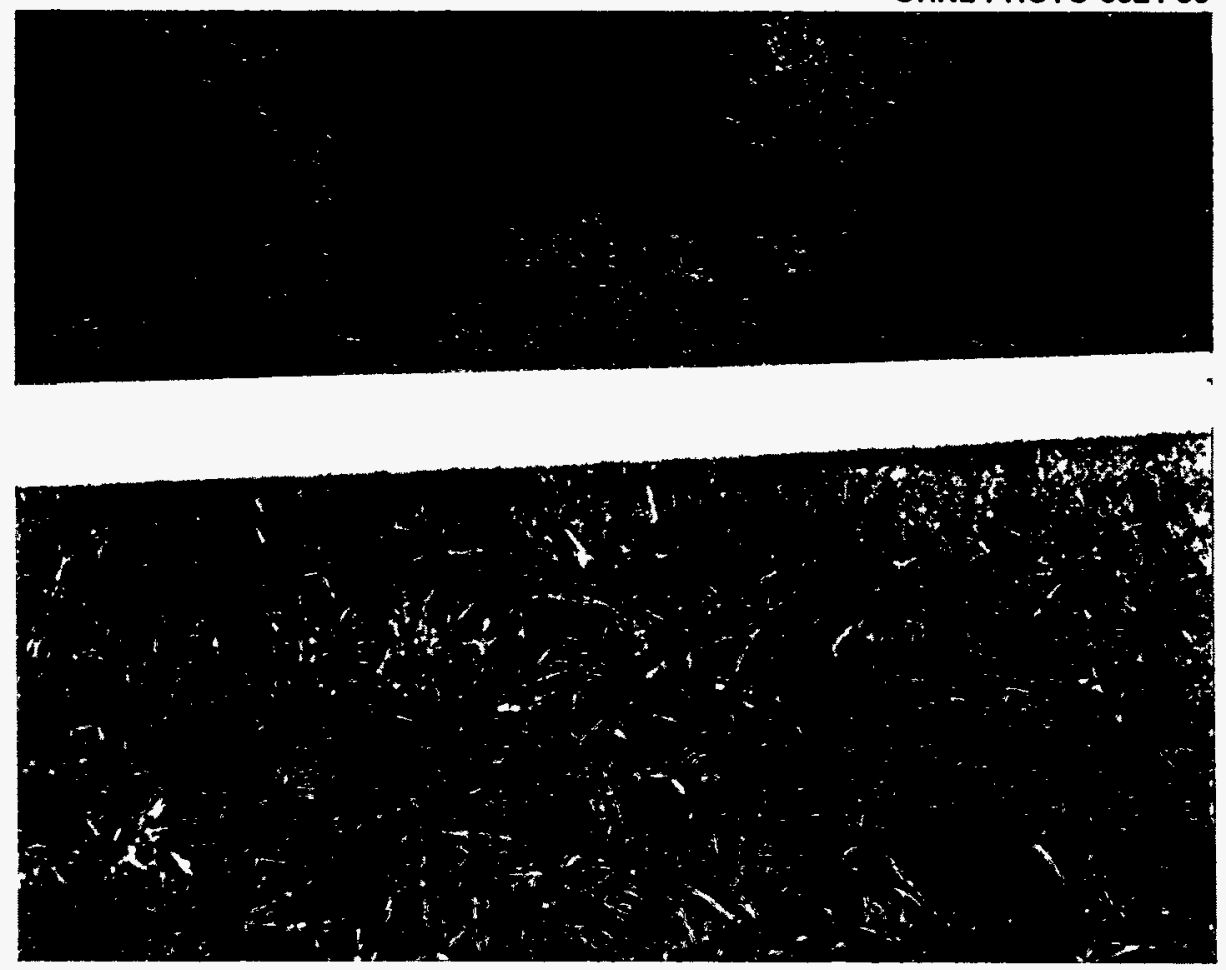

Fig. E.17. View looking north at "flagged" surface hot spot locations near Melton Valley Drive (1994).

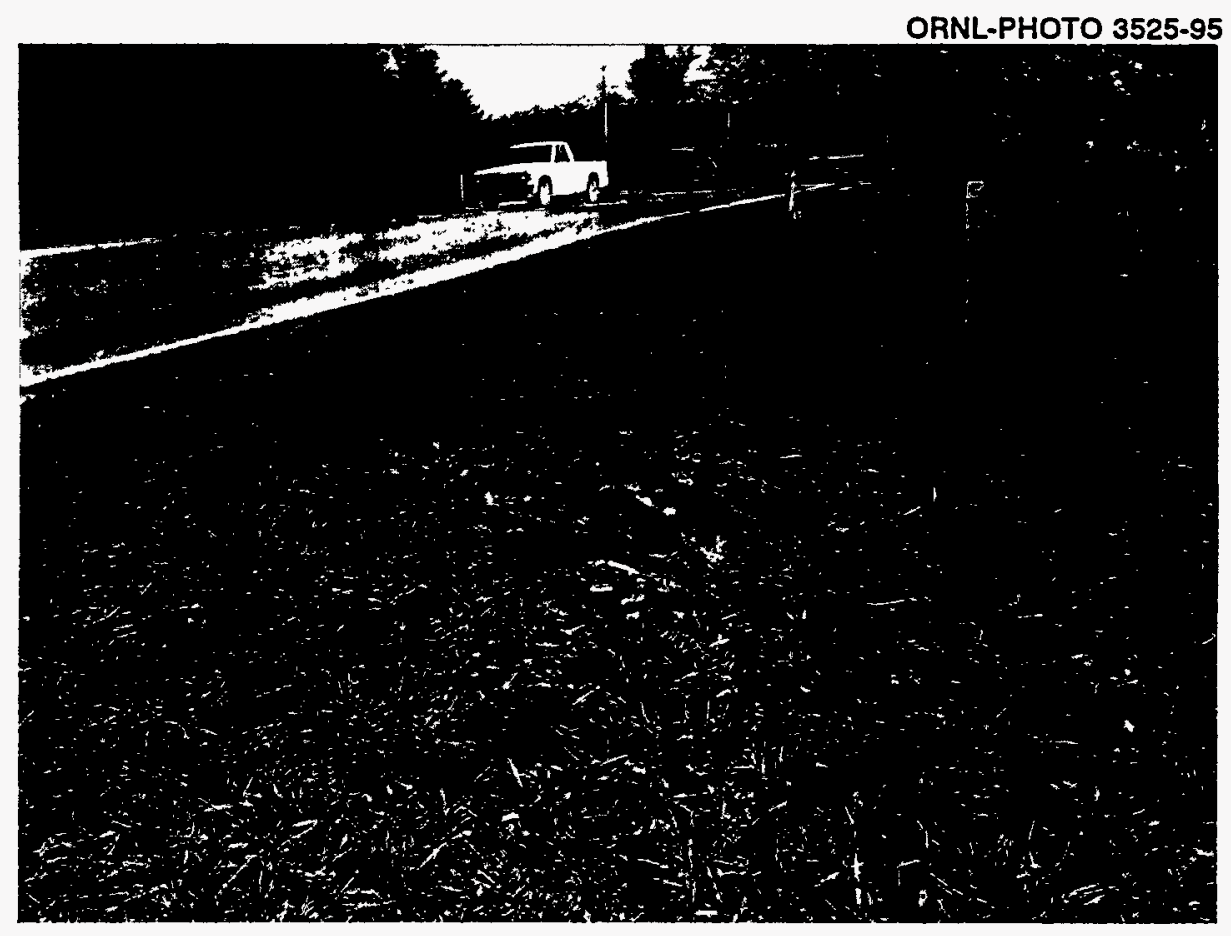

Fig. E.18. View looking northeast at gravel-covered surface hot spot locations near Melton Valley Drive (1994). 


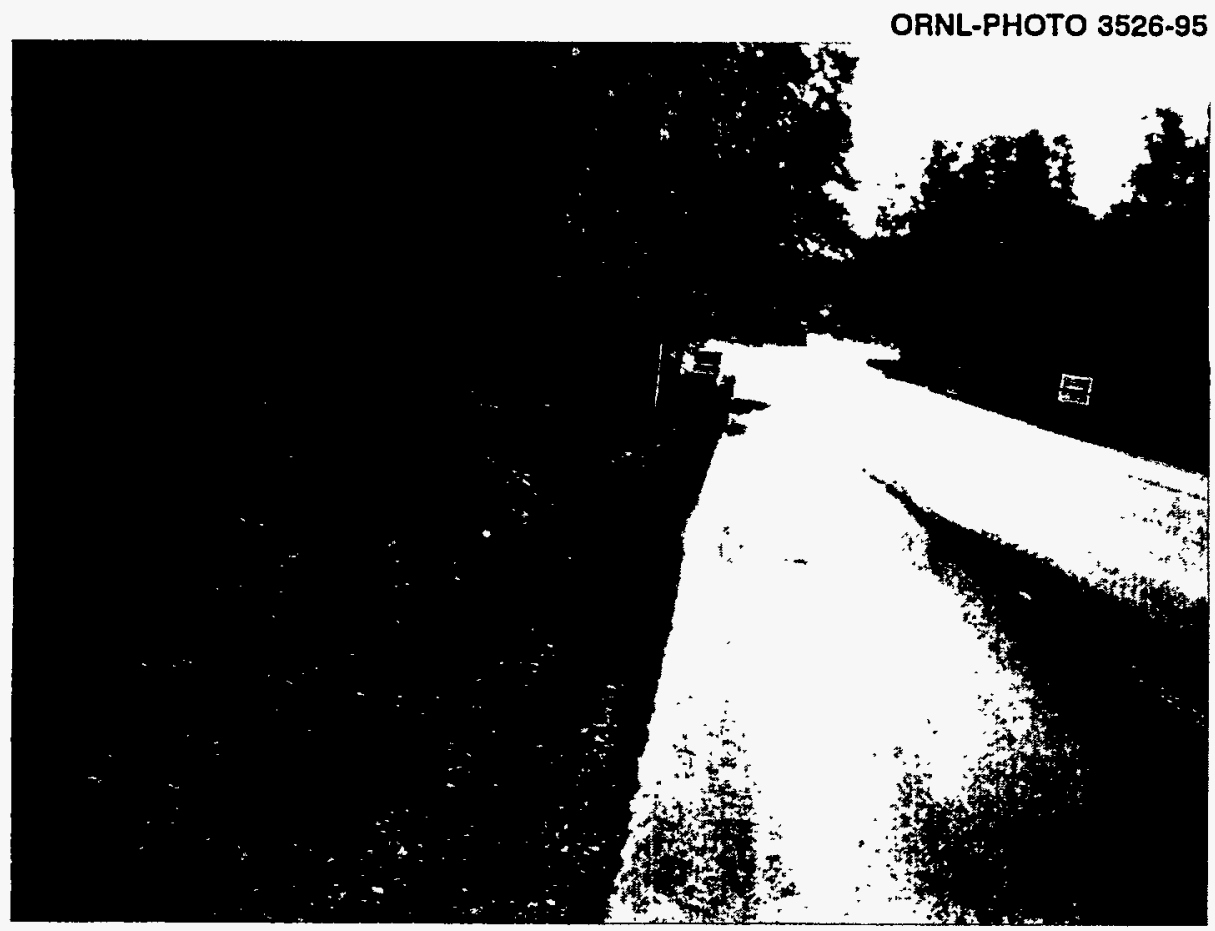

Fig. E.19. View of State Highway 95 looking south toward intersection with Lagoon Road. The remediated hot spots were primarily located on the east shoulder of State Highway 95 (1994).

ORNL-PHOTO $3527-95$

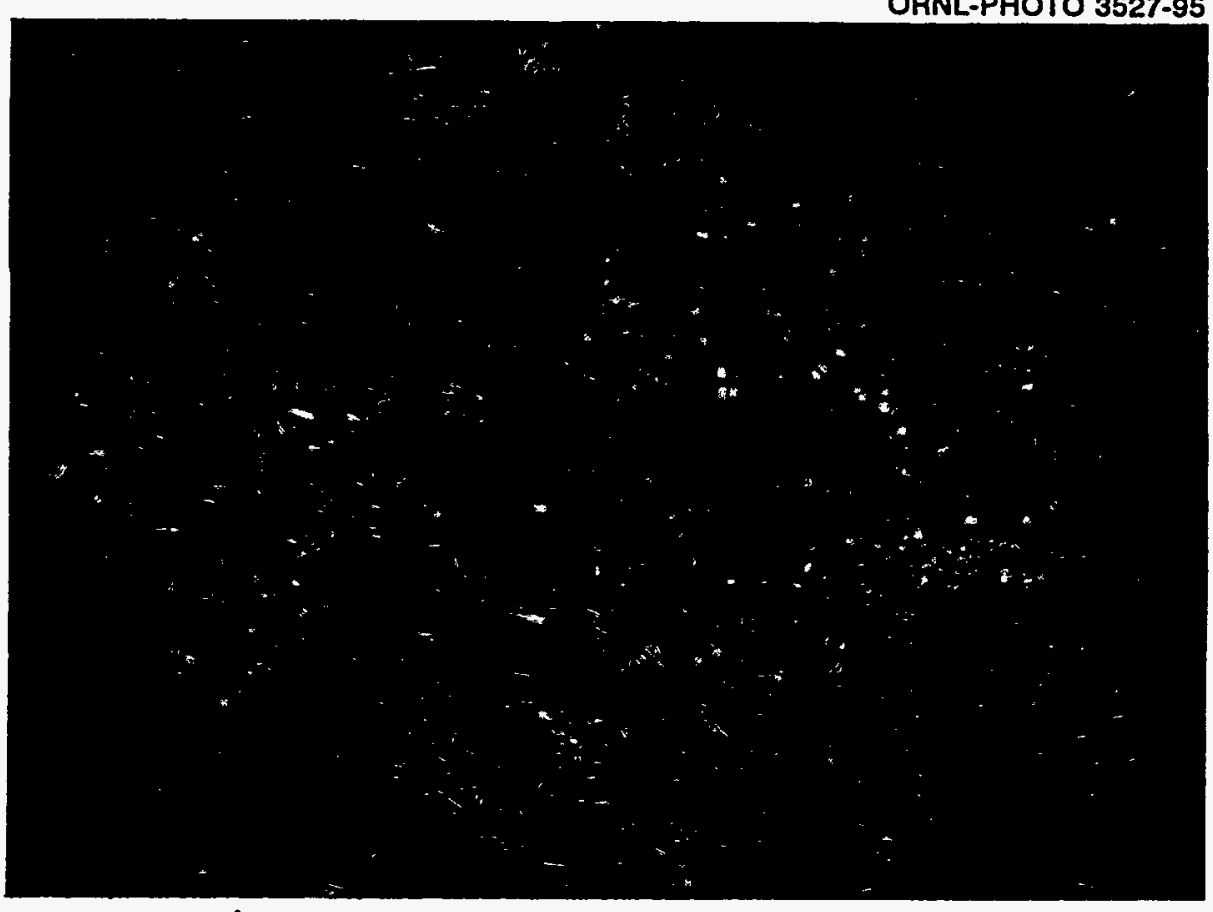

Fig. E.20. View of hole where excavation was conducted at a surface hot spot near the east shoulder of State Highway 95 (1994). 


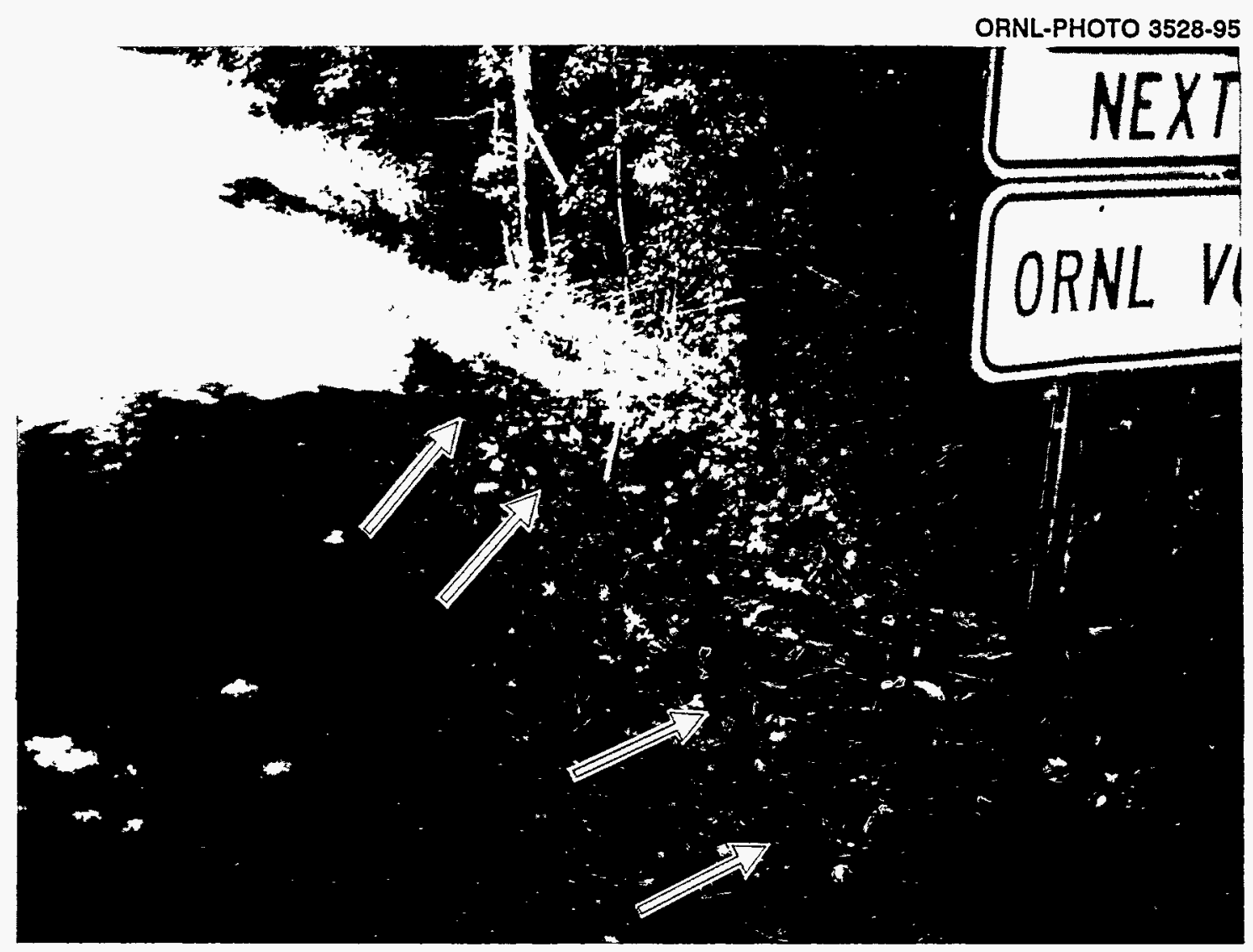

Fig. E.21. View looking north at remediated hot spots found along the shoulder area of State Highway 95 (1994). Arrows indicate areas of cleanup. 



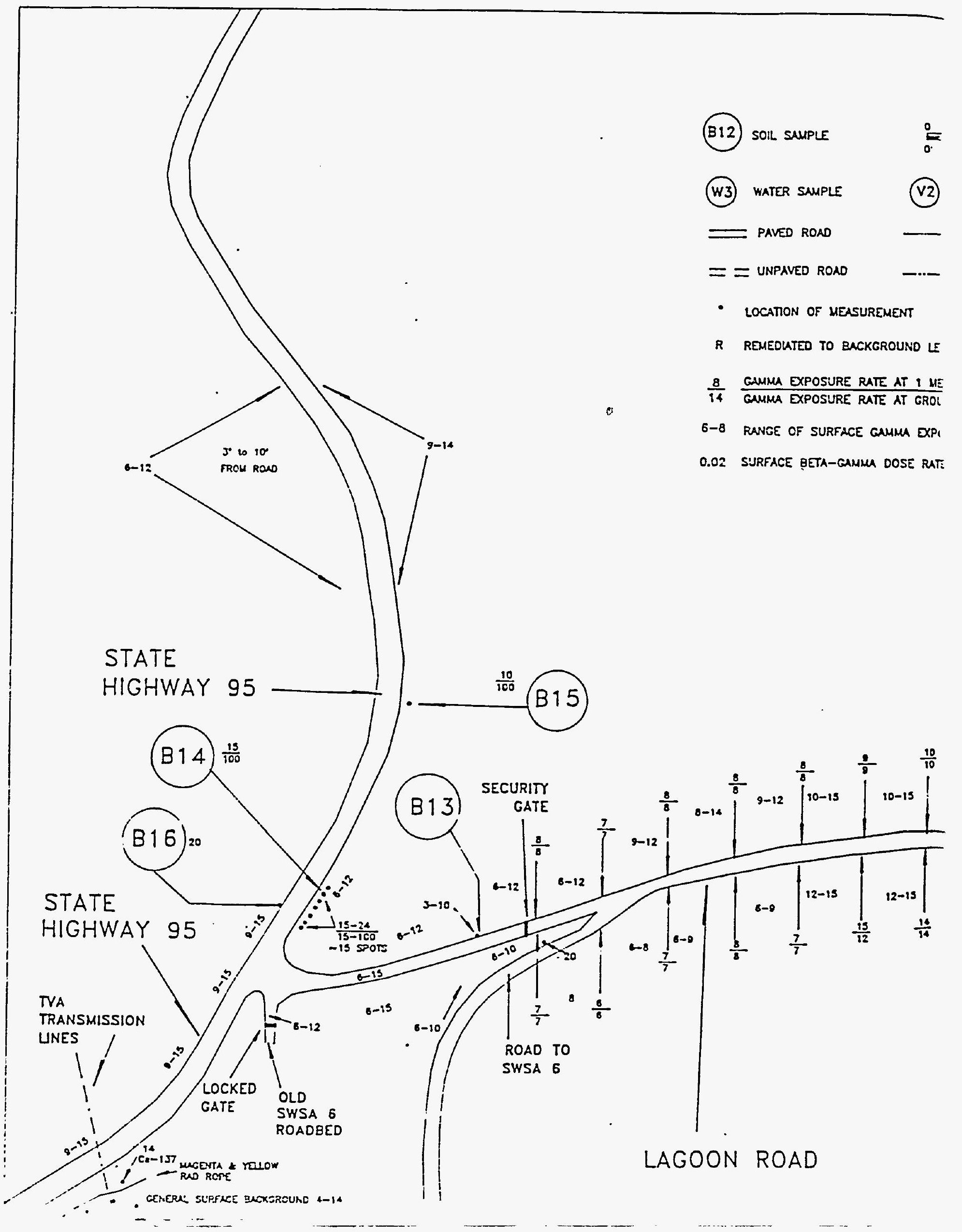


$\bullet$ 
(B12) soll suple

(W3) WATER SAMPLE

= PAVED ROAD

$==$ UNPAVED ROAD

- LOCATION OF MEASUREMENT

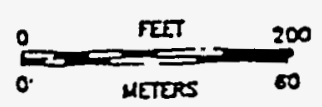

(V2) VEGETATON SAMPIE WASTE UNE

-..- FENCE

- R REMEDUTEO TO BACKGROUND LEVES

$\frac{8}{14} \frac{\text { CAMMA EXPOSURE RATE AT I UETER }}{\text { CMMMA EXPOSURE RATE AT GROUNO SURFACE }}(\mathrm{RR} / \mathrm{h})$

6-8 RUNGE OF SURFACE CMMM EXPOSURE RATES $(\mu R / h)$

0.02 SURFACE BETA-GAMHL COSE RATES (mrod/h)
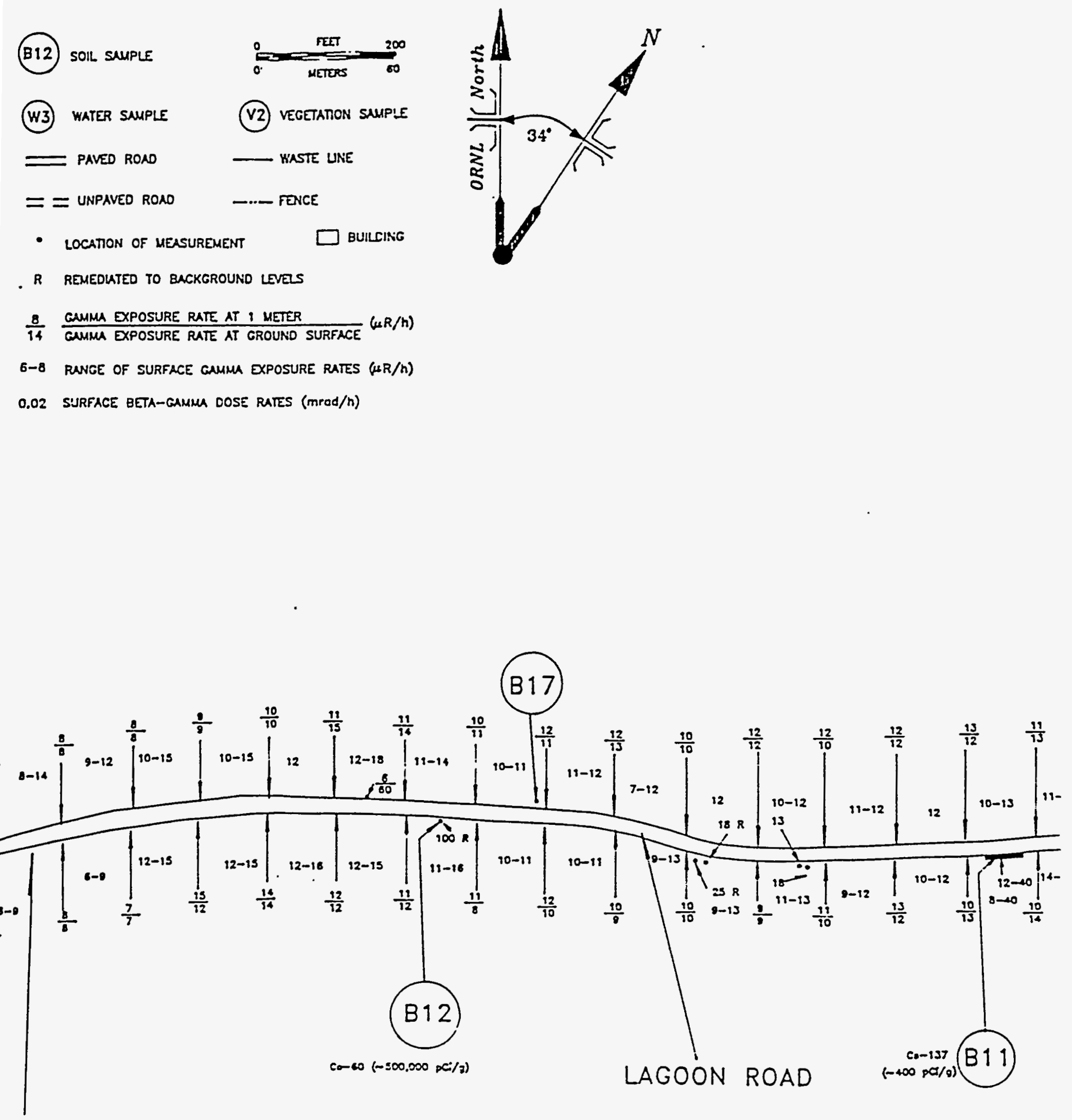


.




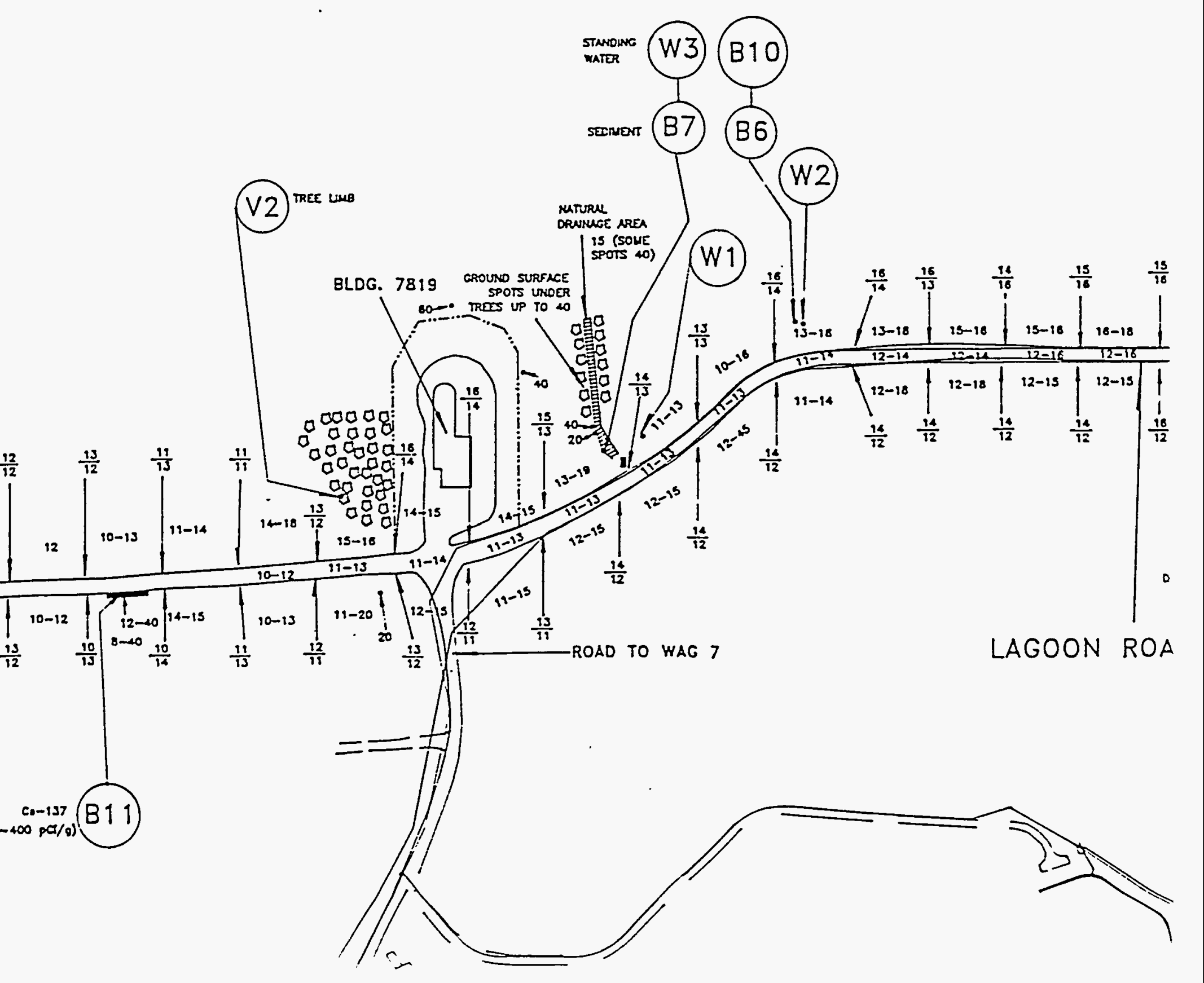





\section{nma Survey Data.}

I당

$2 \times 2 \times 100$

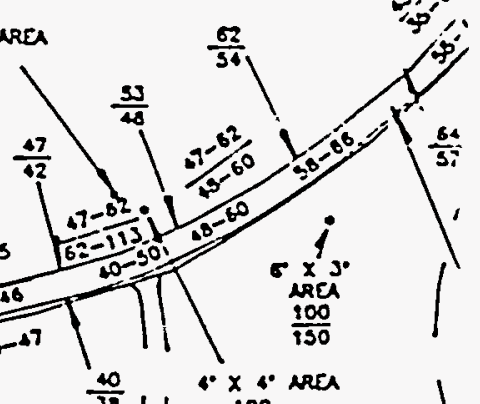

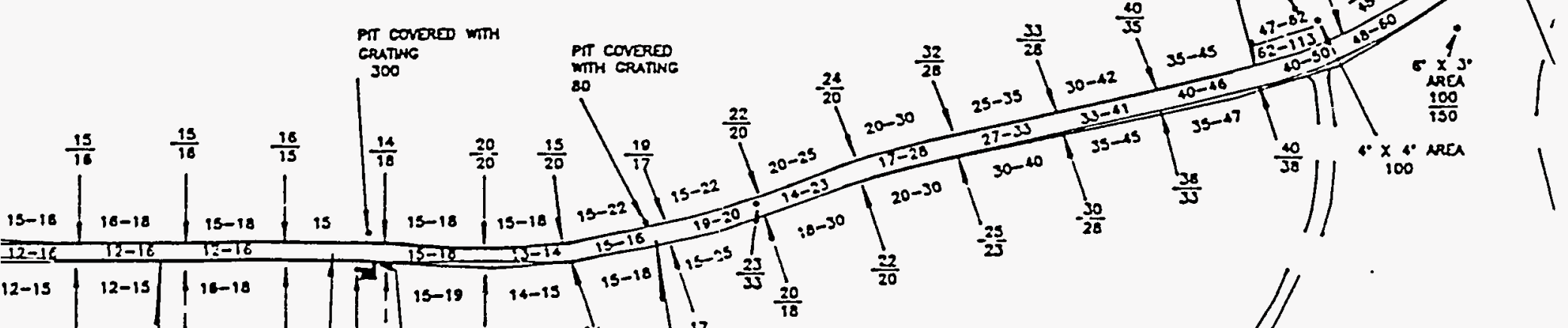
$\frac{1}{12}$

GOON ROAD

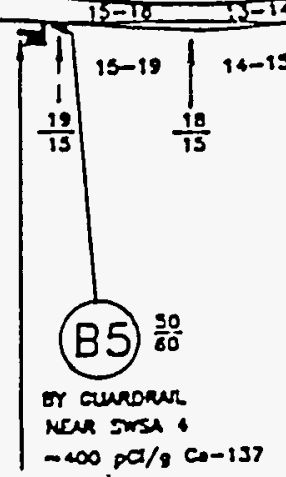

(B9) $\frac{2.000}{19.000}$

Nen conchre $=0$ 3900 no/ Co-13:

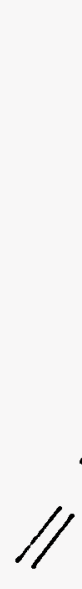

LAGOON ROAD
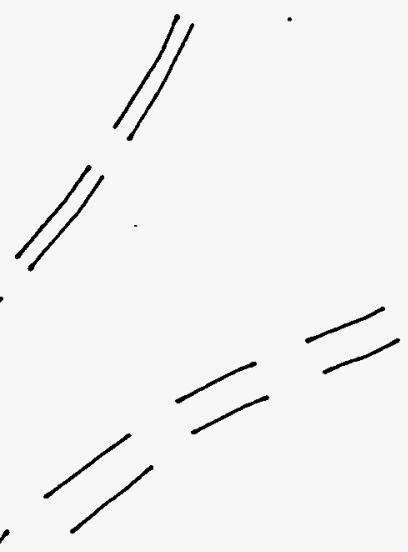
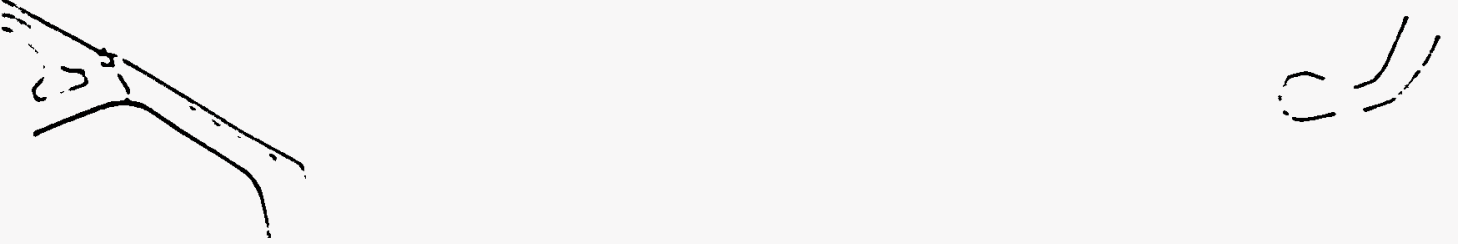



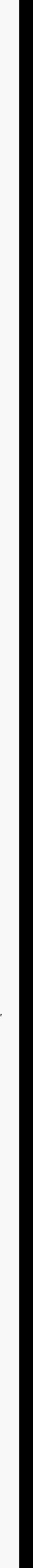




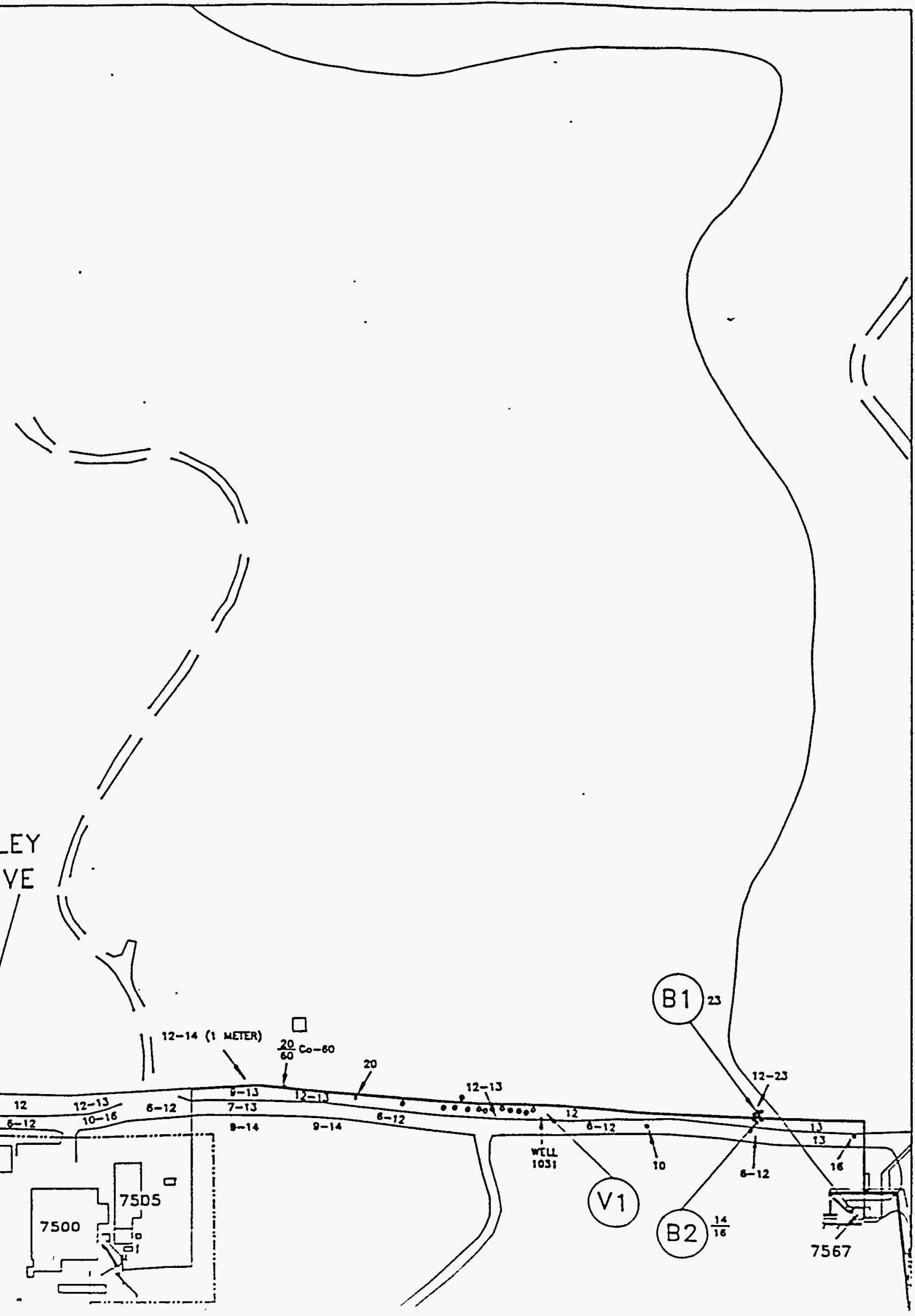

ELTON VALLEY
DRIVE 


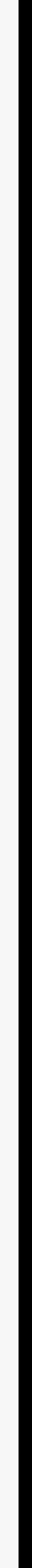




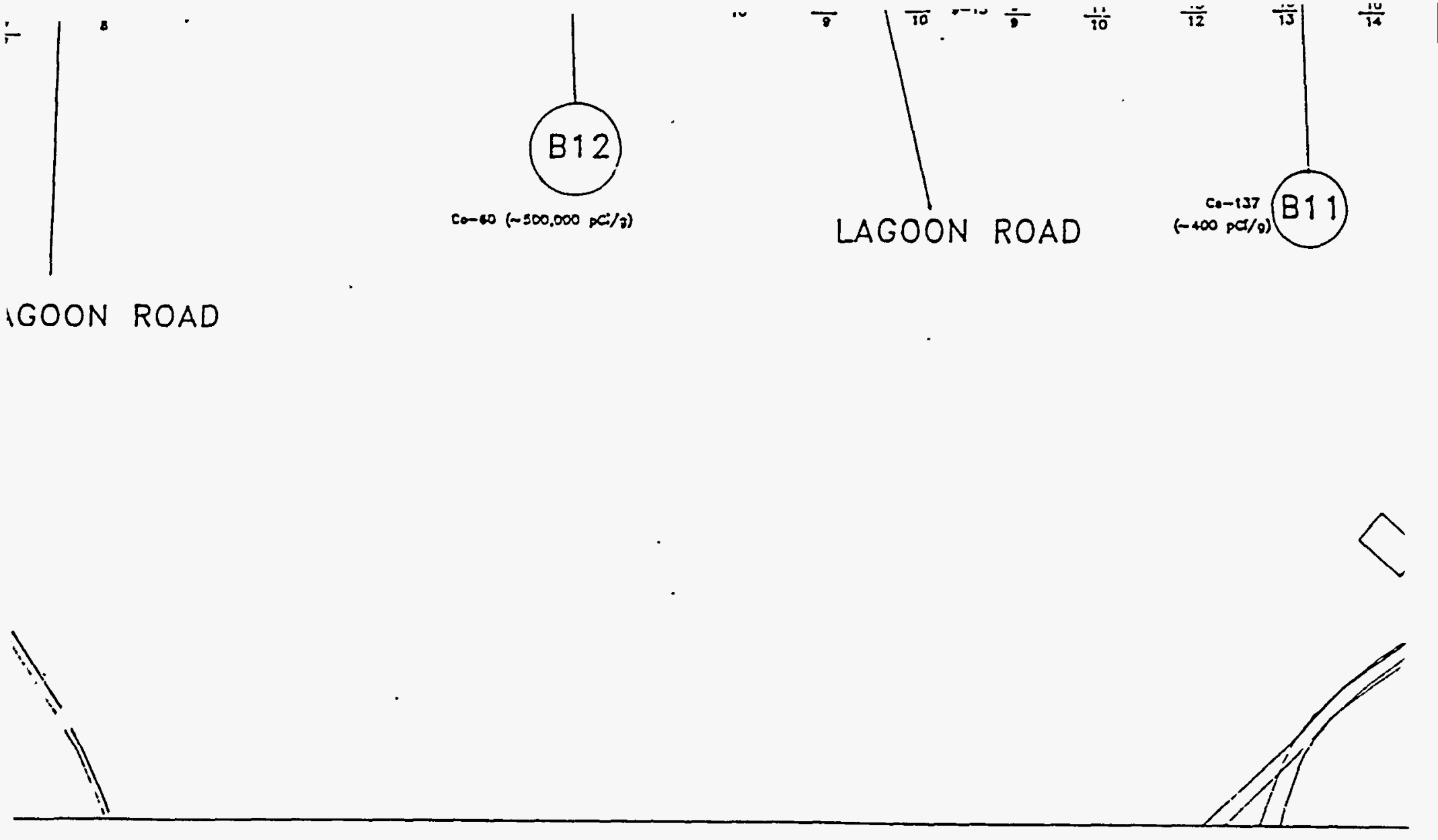





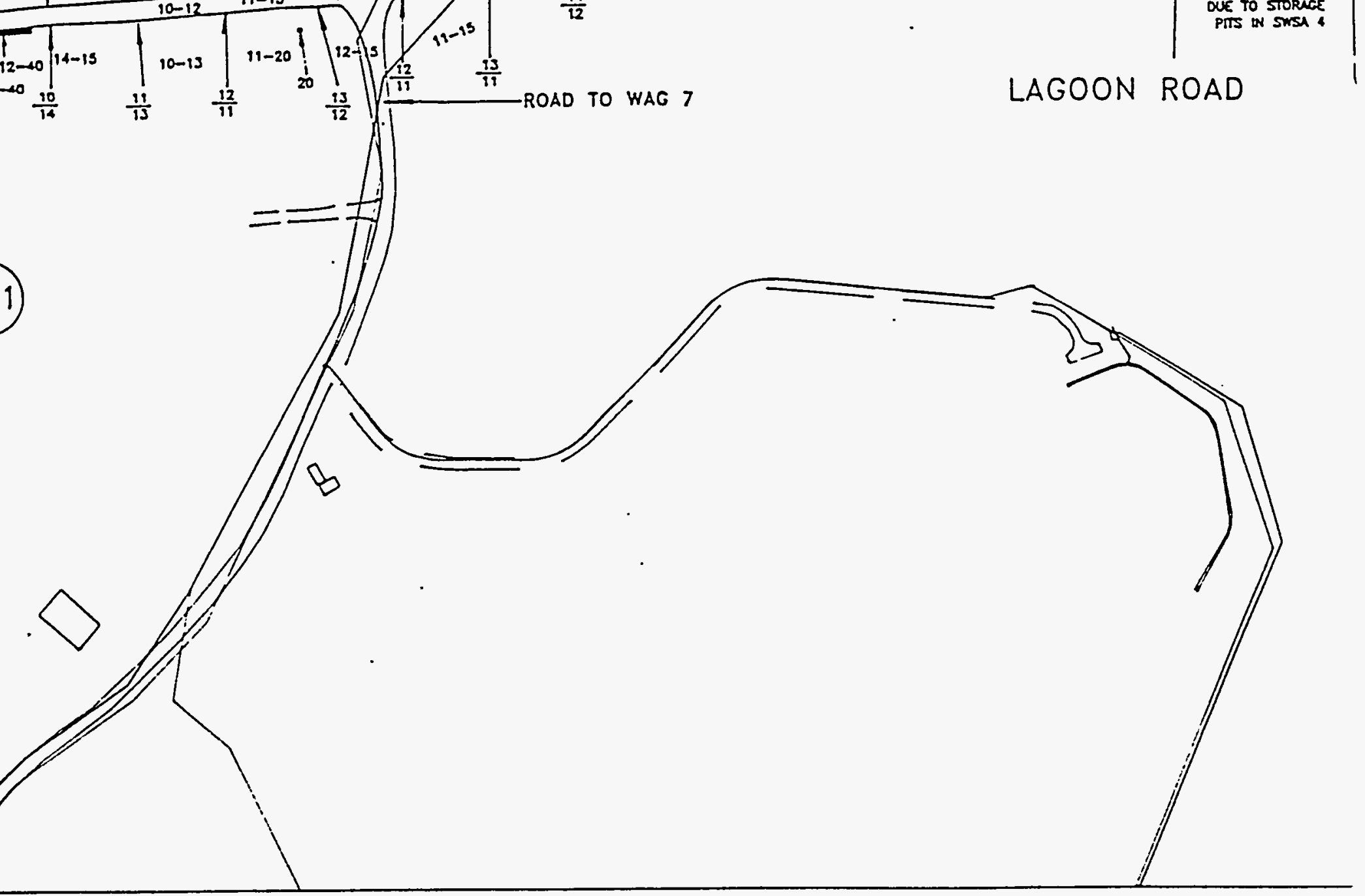




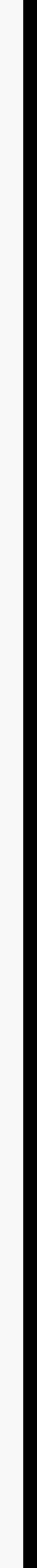



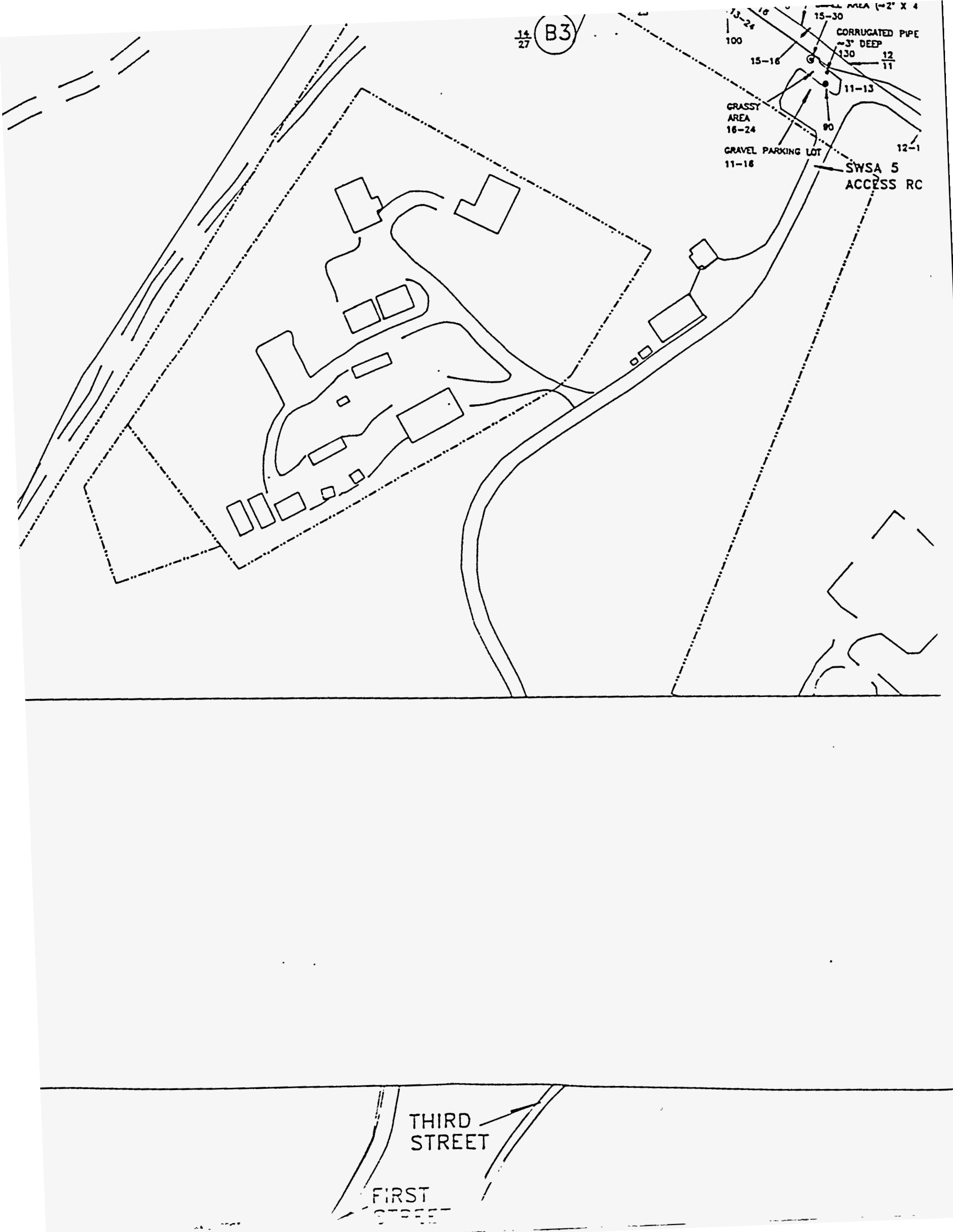


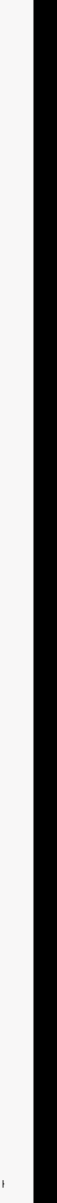




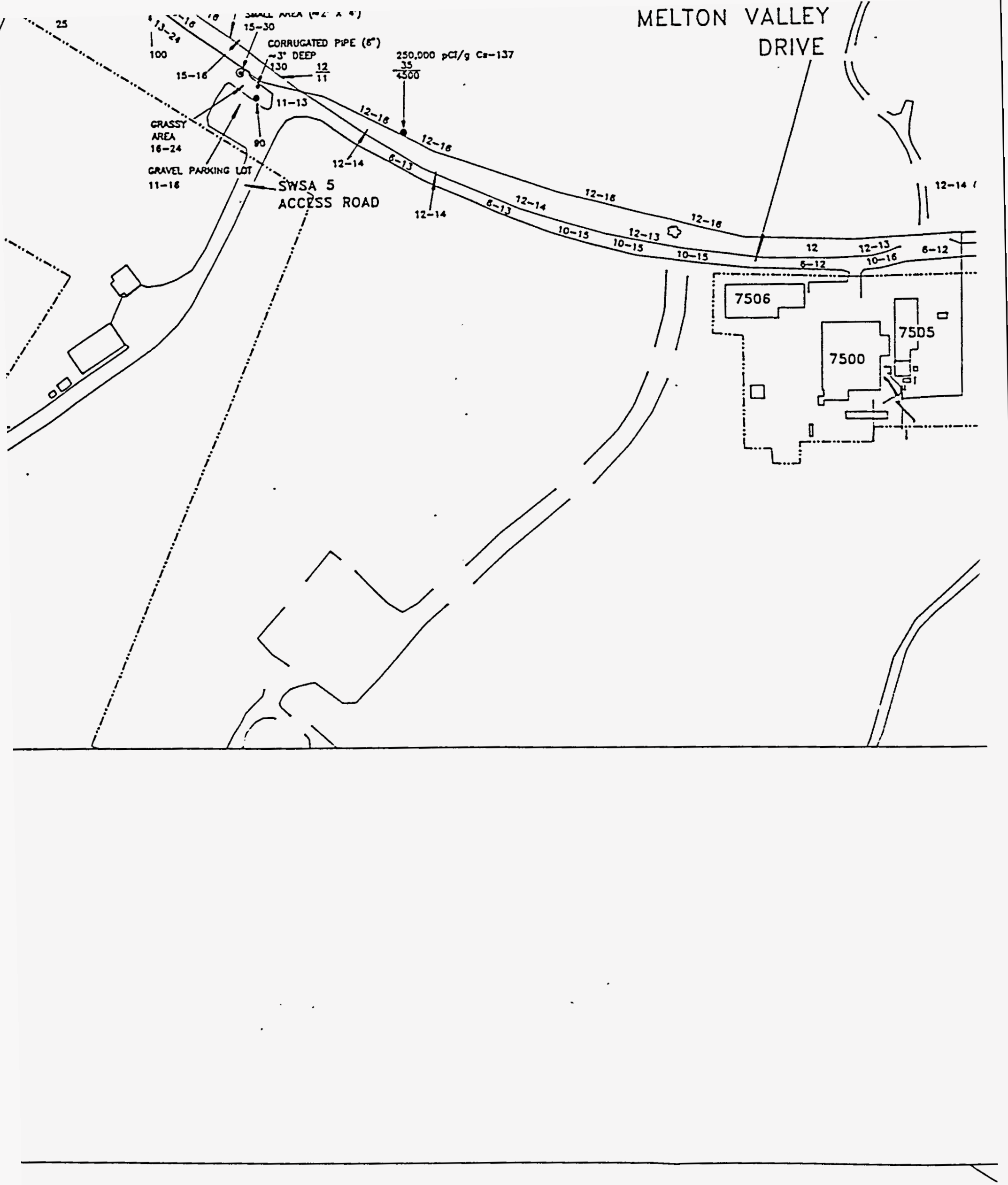




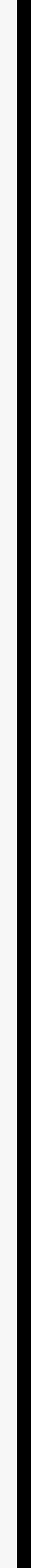




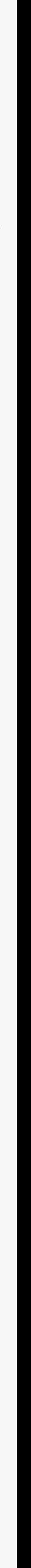




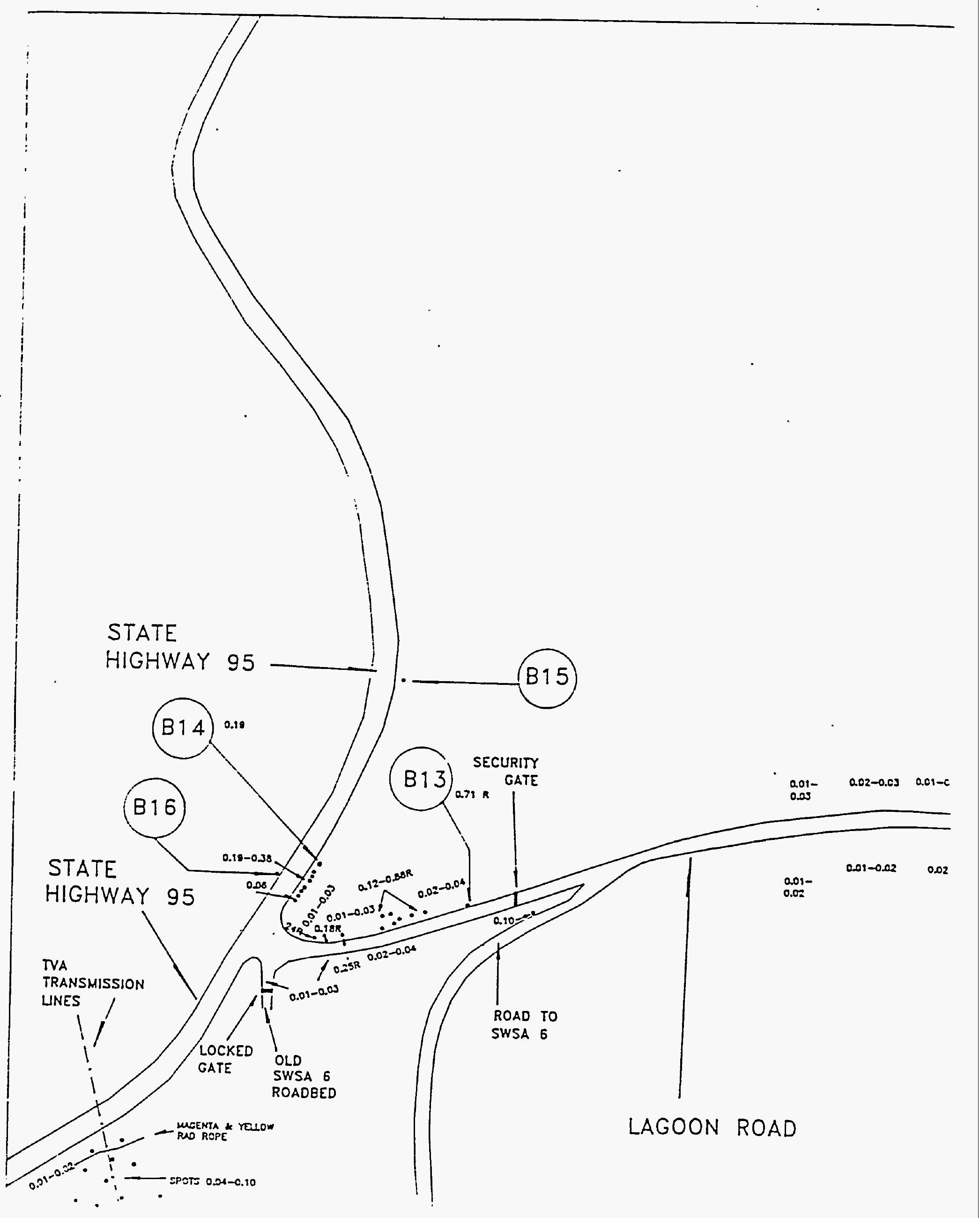





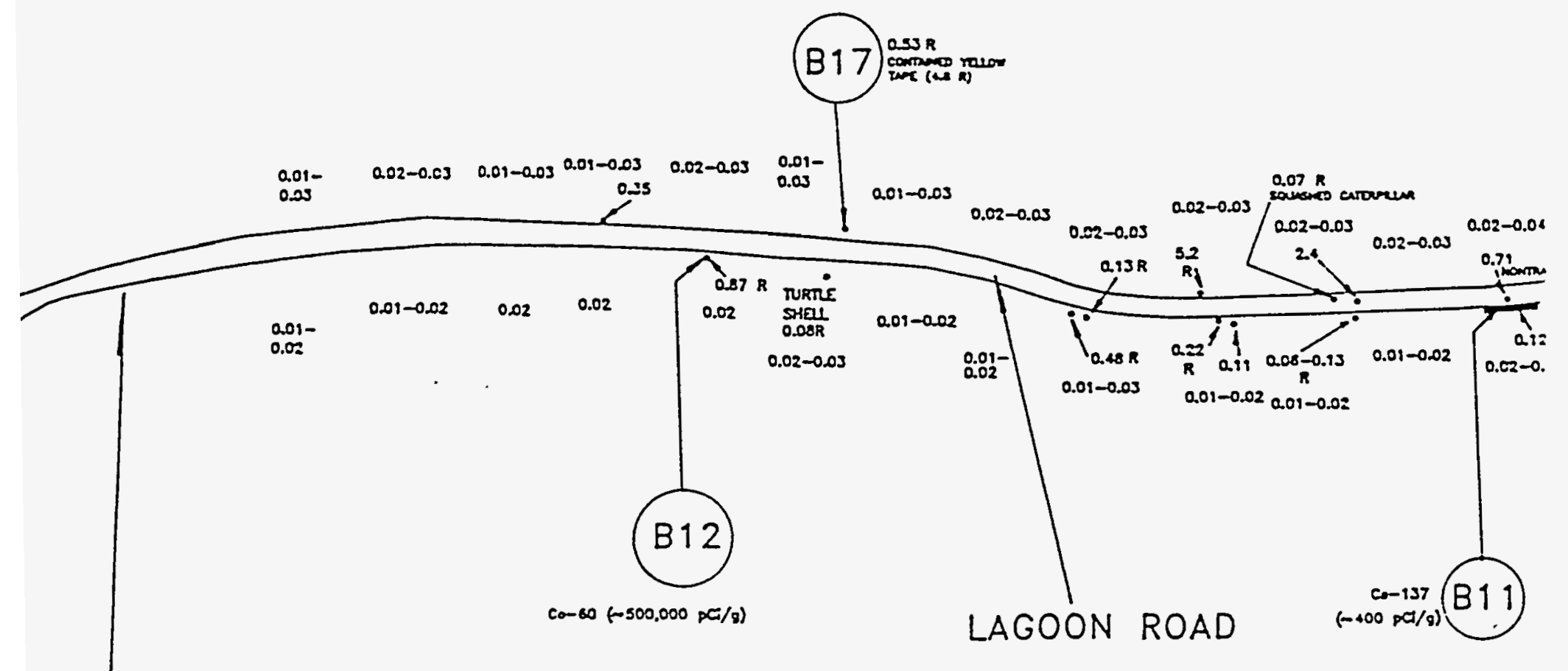




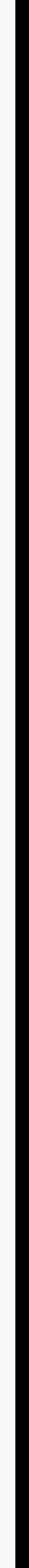




\section{$B e \pm a-G c$}

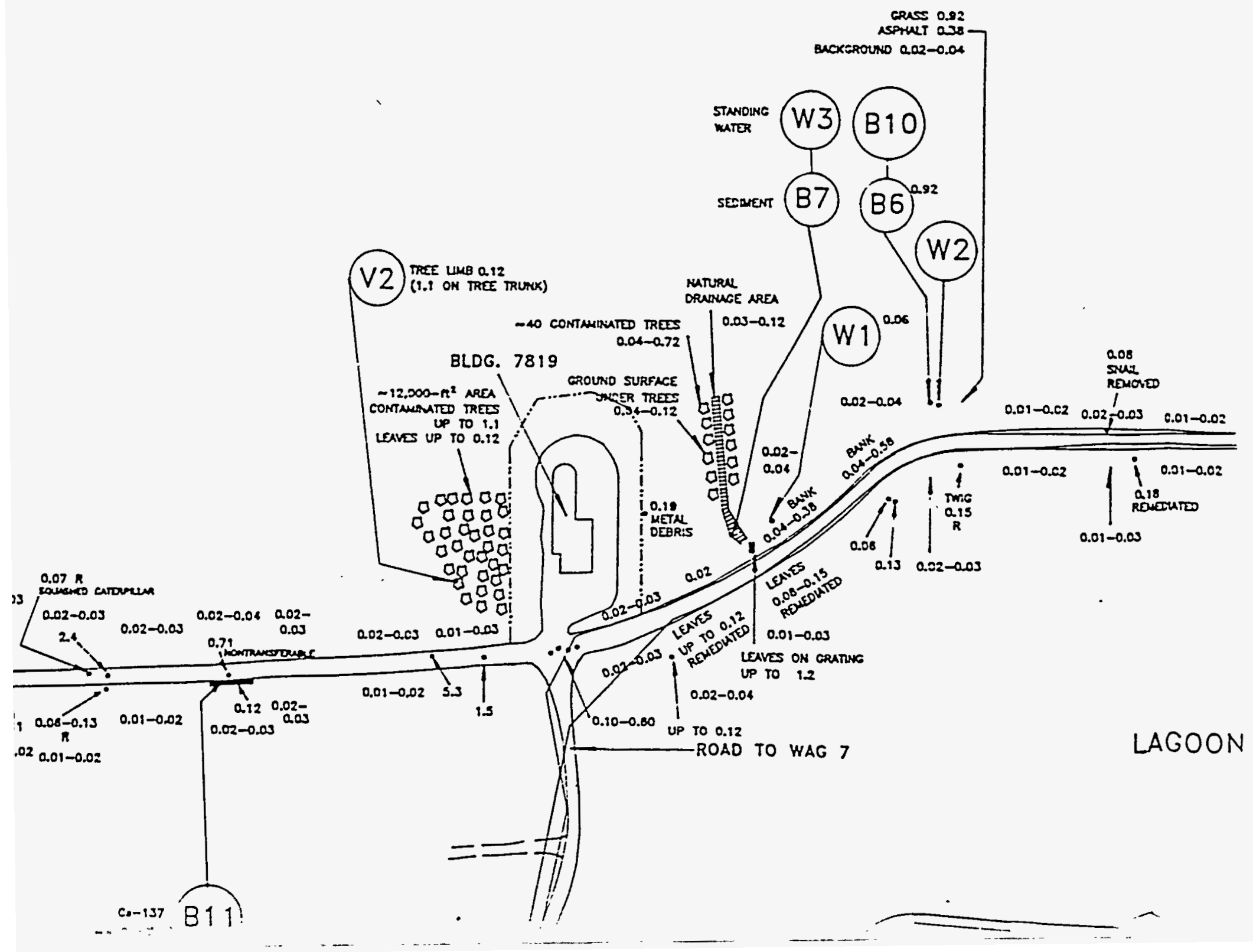




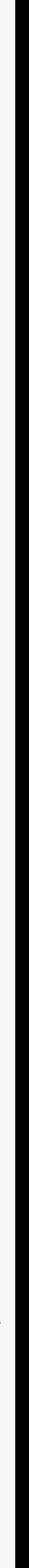





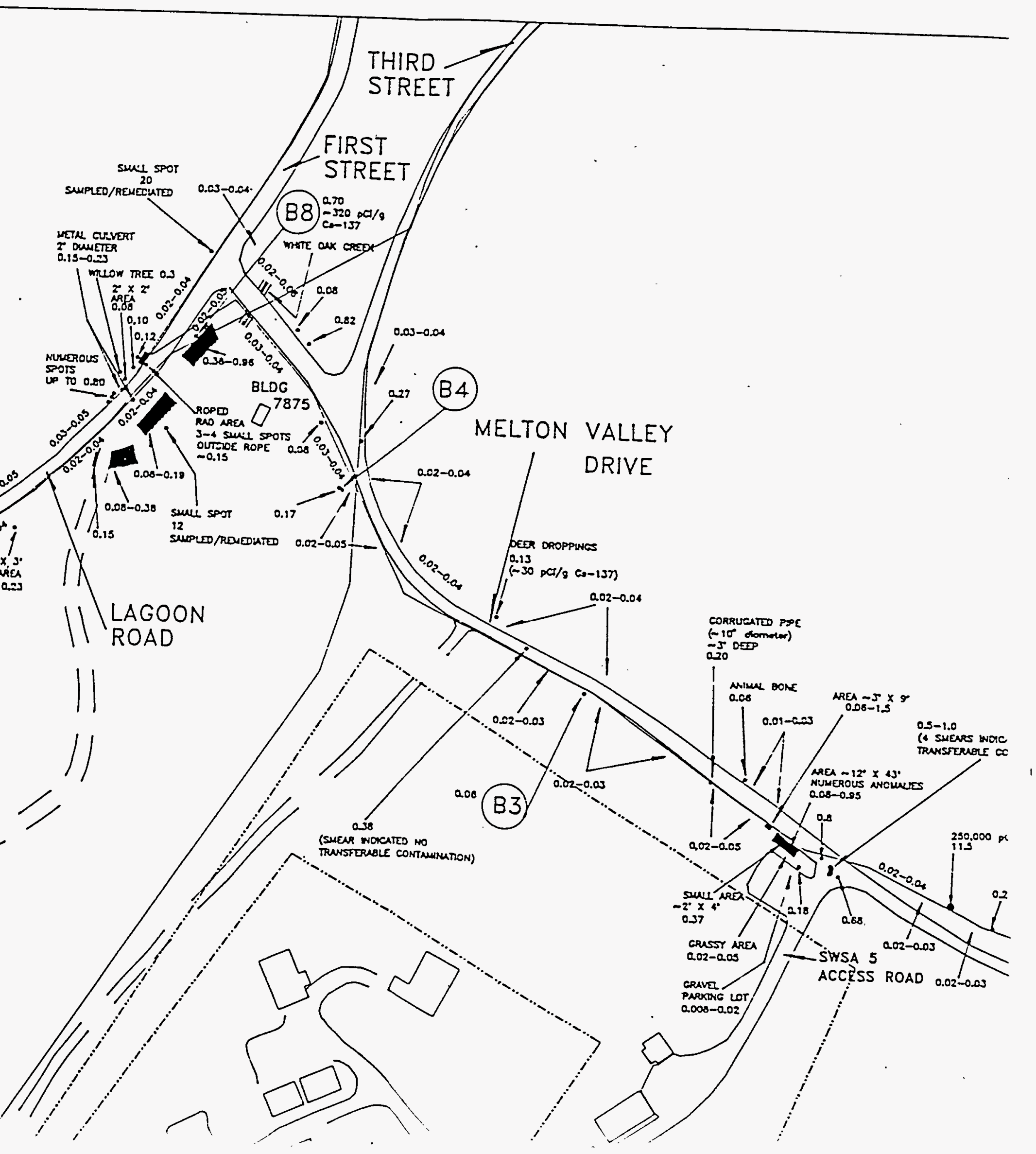






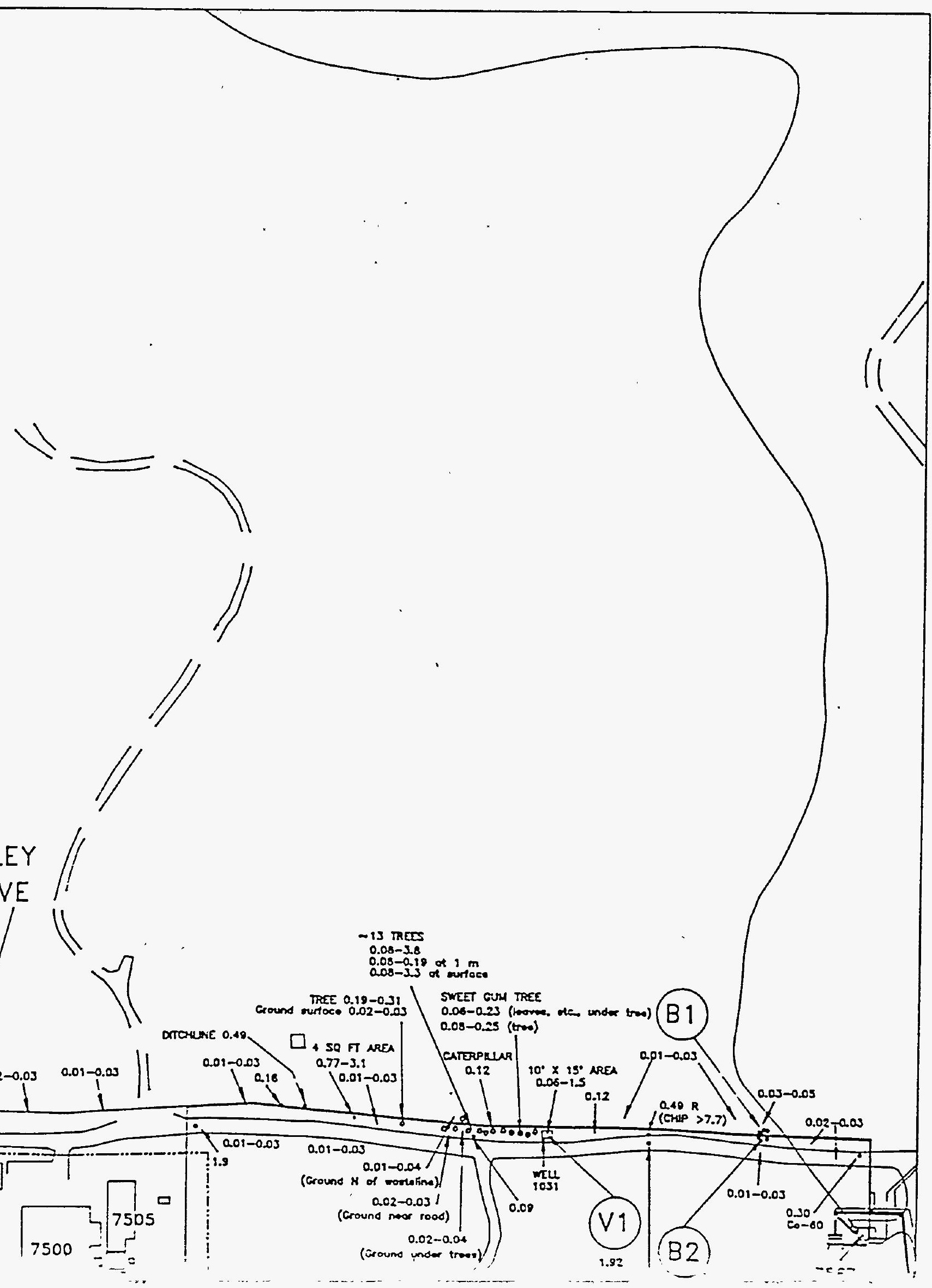





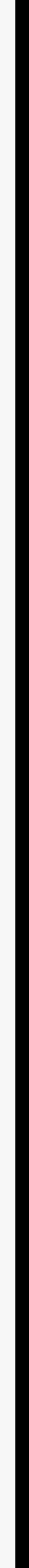




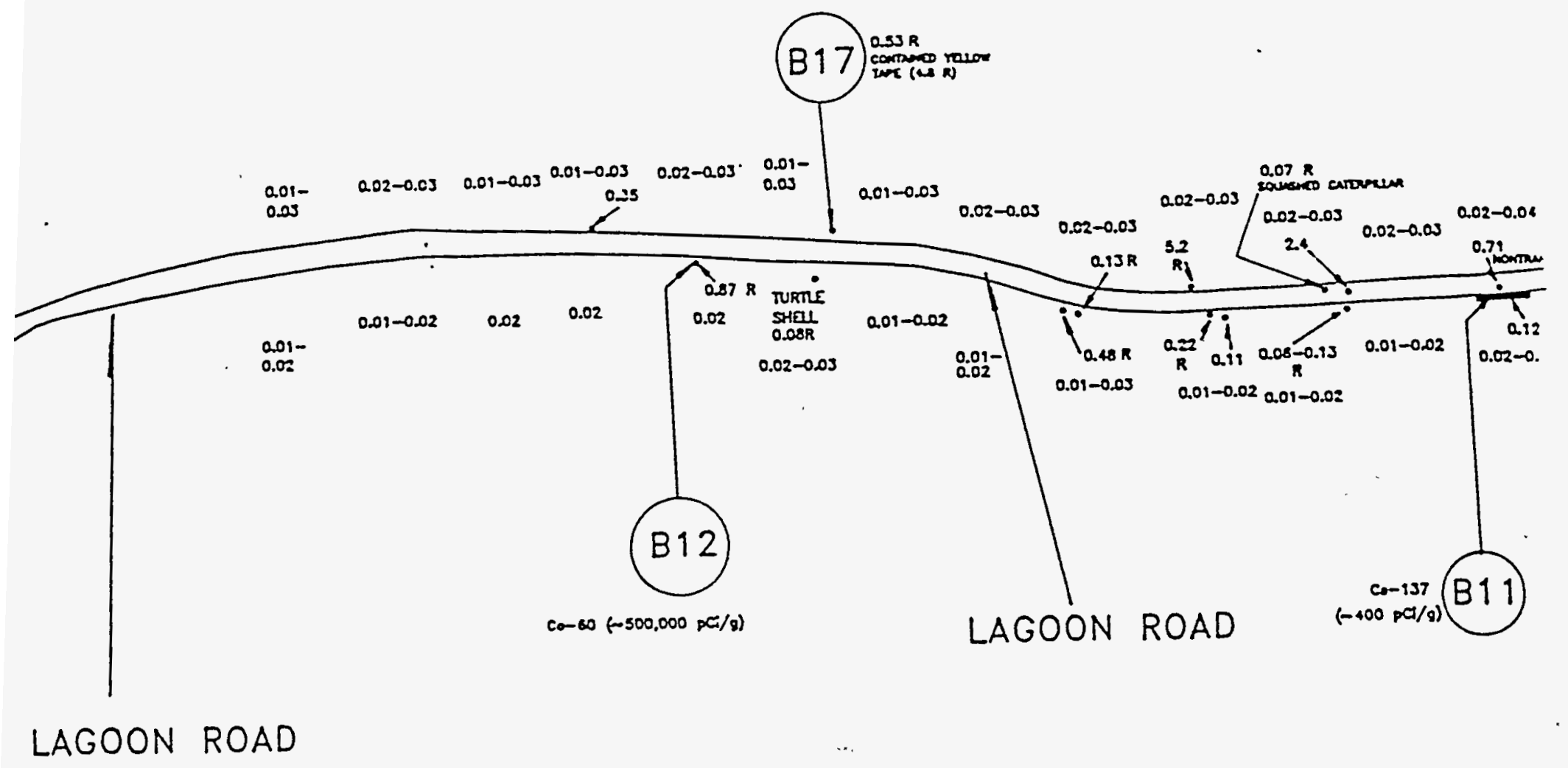

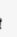

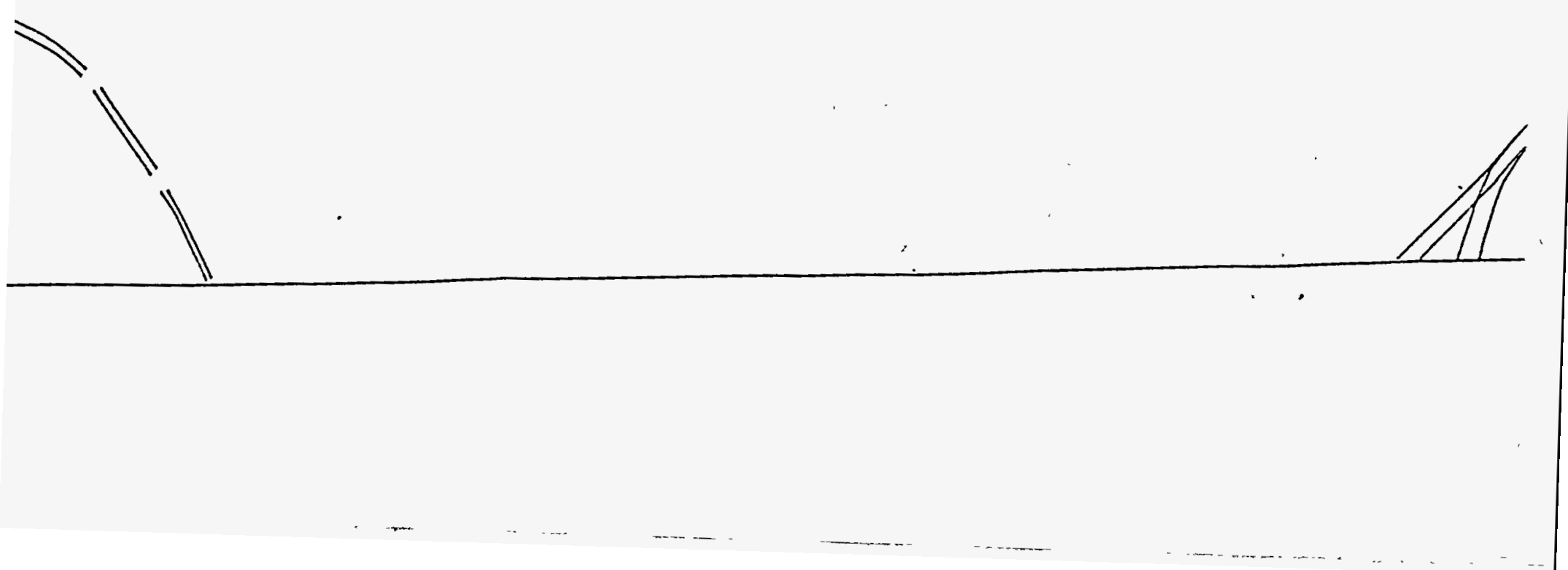






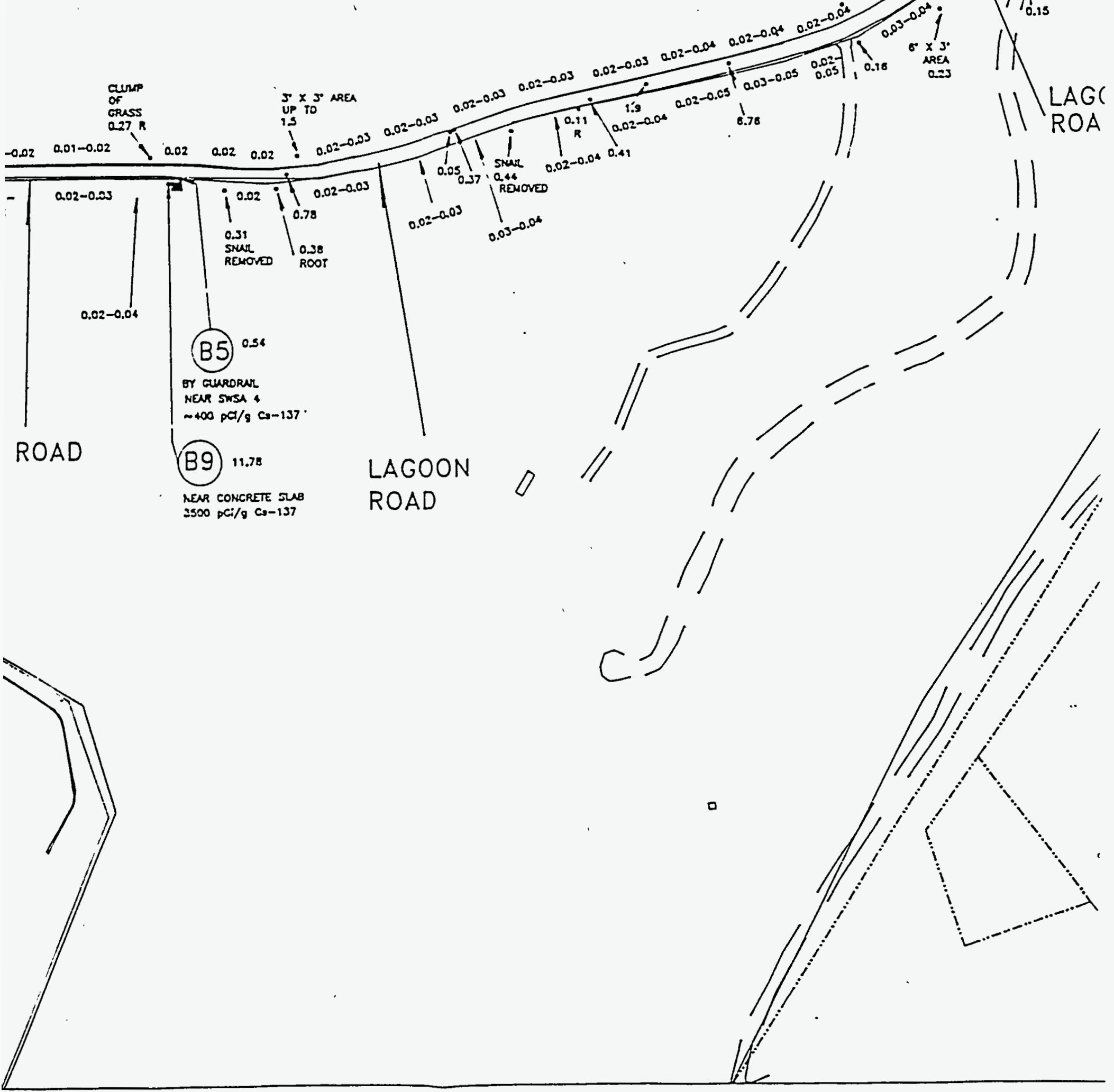

gamma exposurc rates in $\mu \mathrm{R} / \mathrm{h}$ (top) and surface beta-gamma dose rates in mrad/h (bottom) at the surveyed area alor 




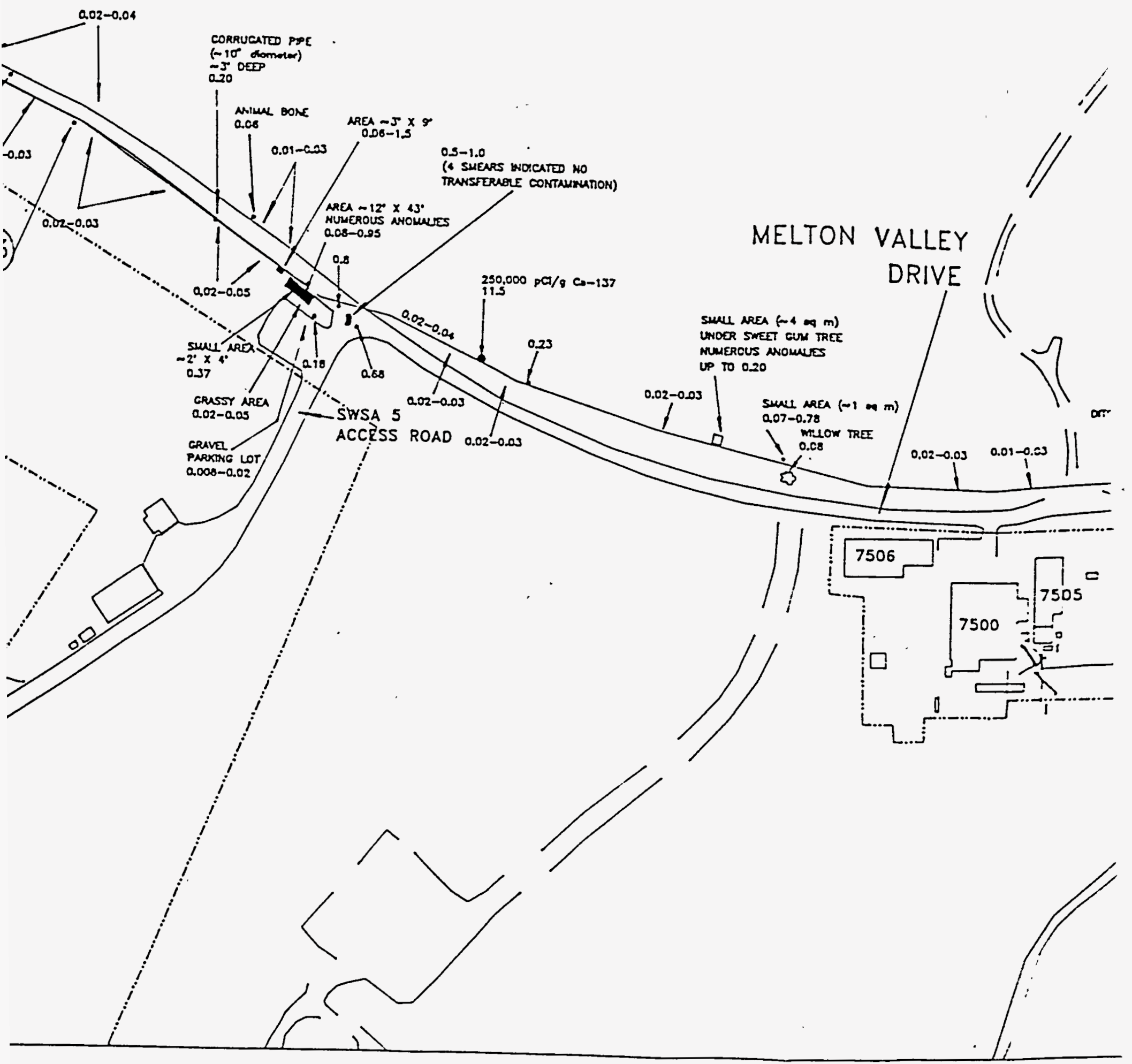


$$
\text { " }
$$ 


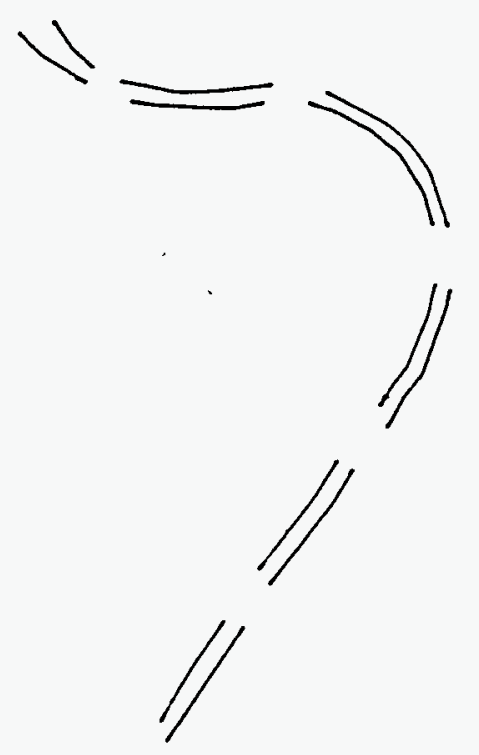

\section{LTON VALLEY \\ DRIVE}

$-40 \mathrm{ml}$

Cun TRE

Dute

11 MAE $(-1$ ค9 $m)$

$7-0.78$

WrLow TREI

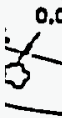
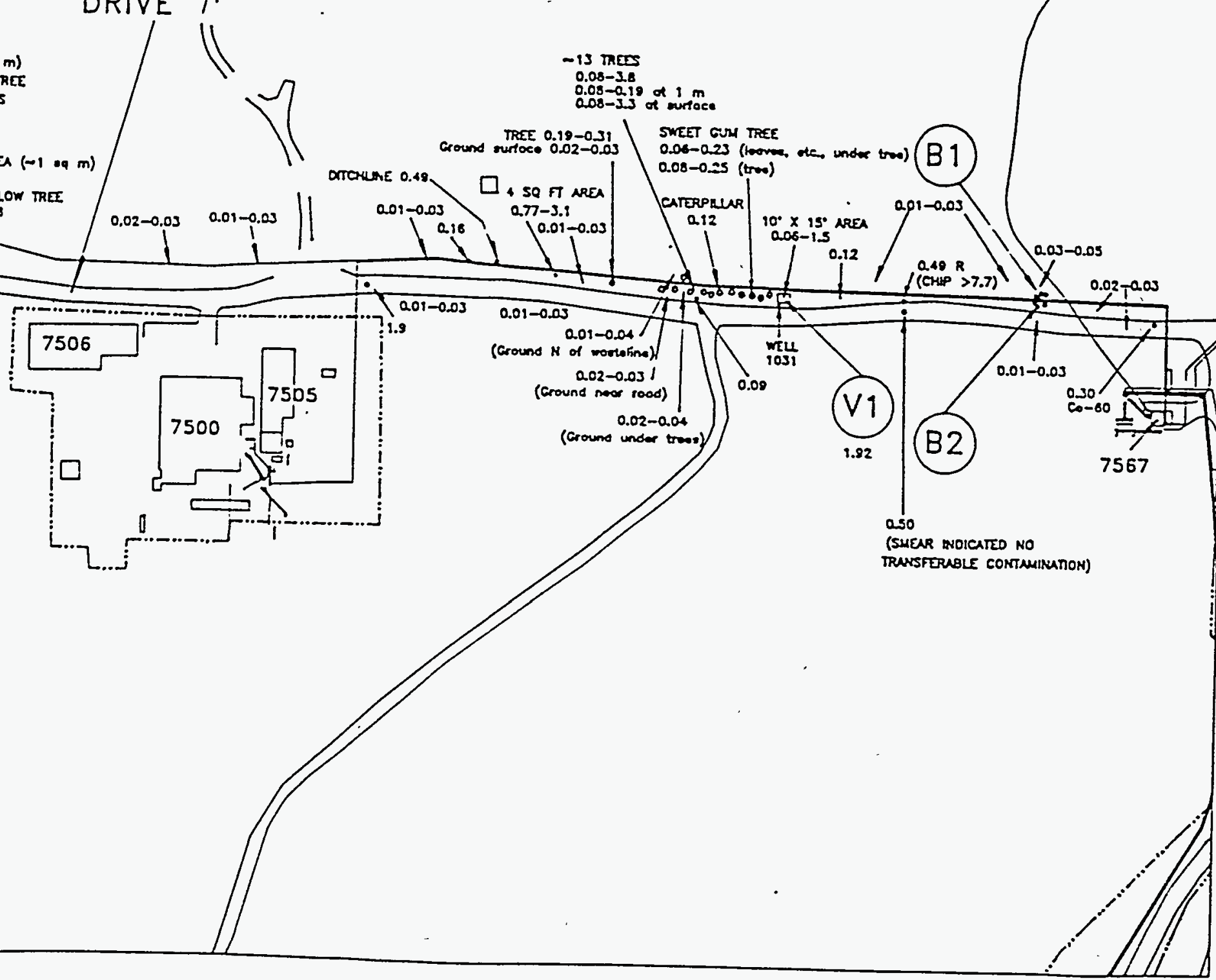

ORNL/ER-327

\section{DISTRIBUTION}

1. B. A. Berven

2. H. L. Boston

3. R. L. Coleman

4. R. D. Foley

5-7. J. H. Hooyman

8-10. D. M. Matteo

11. M. E. Murray

12-13. P. T. Owen

14. P. S. Rohwer

15. R. E. Swaja

16-18. P. F. Tiner
19-20. M. S. Uziel

21-25. J. K. Williams

26. P. S. Wood

27-29. H. D. Wooten

30-35. MAD Records Center

36. Central Research Library

37. ORNL Technical Library, Y-12

38. Laboratory Records Dept.

39-41. Central ER Doc. Managemnt. Ctr. 42-44. ORNL ER Doc. Management Ctr.

45. Office of Assistant Manager for Energy Research and Development, DOE Oak Ridge Operations Office, P.O. Box 2001, Oak Ridge, TN 37831-8600

46-47. Office of Scientific and Technical Information, P.O. Box 62, Oak Ridge, TN 37831 


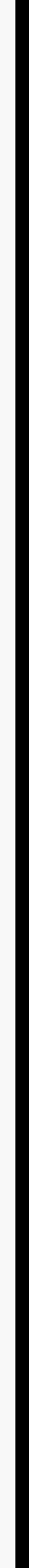

